\title{
A review of bipolarity concepts: History and examples from Radiolaria and Medusozoa (Cnidaria)
}

\author{
S. D. STEPANJANTS ${ }^{1}$, G. CORTESE $^{2}$, S. B. KRUGLIKOVA ${ }^{3}$ \& K. R. BJØRKLUND ${ }^{4}$ \\ ${ }^{1}$ Zoological Institute, Russian Academy of Sciences, St Petersburg, Russia, ${ }^{2}$ Alfred Wegener Institute for Polar and Marine \\ Research, Bremerhaven, Germany, ${ }^{3}$ P.P. Shirshov Institute of Oceanology, Russian Academy of Sciences, Moscow, Russia $\mathcal{E}$ \\ ${ }^{4}$ Natural History Museum, Department of Geology, University of Oslo, Norway
}

\begin{abstract}
Bipolarity, its history and general interpretation are investigated and discussed herein. Apart from the classical view, namely that a bipolar distribution is a peculiar biogeographical phenomenon, we propose that it is ecologically controlled too. This approach was used for bipolarity assessment within the following groups: Phaeodaria, Nassellaria, Spumellaria (Radiolaria) and Medusozoa (Cnidaria). We recognize 46 bipolar radiolarian species and three radiolarian genera. However, although species concepts in radiolarians are relatively stable and well known, the high-rank taxonomy of radiolarians is still not well defined. Caution should therefore be taken in the interpretation of distribution data at a taxonomic level higher than the species. In the Medusozoa, bipolarity is observed for 23 species and 32 genera. The different ways in which bipolarity can develop are discussed under the different groups, but preference has been given to the recent and most probable routes of migration. In our investigation of the bipolarity phenomenon, we reviewed more than 400 articles dealing with taxonomy, ecology and biogeography of the modern fauna in both groups.
\end{abstract}

Key words: Biogeography, bipolarity, Medusozoa, Radiolaria

\section{Introduction}

The bipolarity phenomenon is herein investigated using examples from the exclusively pelagic classes Euradiolaria and Medusozoa (phylum Cnidaria), the latter having both pelagic and benthic stages. In both groups, the phenomenon of bipolarity is very clearly represented: as Radiolaria (Bjørklund, Cortese, Kruglikova) and Cnidaria (Stepanjants) specialists we concentrated on these two groups of organisms, and therefore hope that this paper will be of interest to colleagues studying other living taxa, and thus stimulate debate on the bipolarity problem within other taxonomic groups.

As the term "bipolarity" has different interpretations and meanings, we will first cite the classical definition and then, after a short and critical analysis of the history of this problem, we will offer our own views on this phenomenon.
Bipolarity is an interrupted distribution of identical or closely related species (or higher taxa level) of flora or fauna in polar, temperate or subtropical zones of both hemispheres, characterized by their absence in the tropics (Bergh 1947; Stepanjants et al. 1996, 1997a).

Many publications have been dedicated to different aspects of the bipolarity phenomenon, including some (Stepanjants et al. 1996, 1997a) concentrating on the bipolar distribution of Medusozoa (Cnidaria). The representatives of this group display, during their ontogeny, both benthic and pelagic stages, inhabit all depth horizons, and are distributed in all oceanic provinces. The study of bipolarity in Cnidaria is limited to their Recent representatives, as relict forms and fossils are extremely rare. Stepanjants et al. (1996, 1997a) reported 38 bipolar species and 30 bipolar genera of Hydrozoa and Siphono-

Correspondence: G. Cortese, Alfred Wegener Institute for Polar and Marine Research, Bremerhaven, Germany. E-mail: gcortese@, awi-bremerhaven.de

Published in collaboration with the University of Bergen and the Institute of Marine Research, Norway, and the Marine Biological Laboratory, University of Copenhagen, Denmark 
phora, but the number of bipolar species is adjusted to 23 herein.

Our interest in analysing the bipolar distribution of Radiolaria is connected with Petrushevskaya (1986), who was the first to question the bipolar distribution of some radiolarian species, and with our own knowledge of the geographical distribution of cold-water radiolarian species in the northern and southern hemispheres. Radiolarian skeletal remains are preserved in sediments and, for some species, we are able to provide evidence about the time of their origin and, accordingly, outline how and where their bipolar distribution developed. New data, however, persuaded us that earlier estimates of the bipolarity phenomenon are different from that proposed by classical authors.

\section{The bipolarity concept and its history: From Captain J. C. Ross until today}

James Clark Ross participated on many expeditions in the Arctic and the Antarctic. He was by no means a biologist, but he personally collected and investigated several zoological collections, which made it possible for him to compare faunistic peculiarities from northern and southern polar regions. The results from these observations, based on the collections taken during the H.M.S. Erebus and H.M.S. Terror expeditions from 1839 to 1843 , led by Captain J. C. Ross, have been summarized and published in two volumes. In the first of these volumes (Ross 1847), the idea of a bipolar distribution of some marine organisms was expressed for the first time. Captain Ross traced the deep-water connection between populations of the same, coldwater species from the northern to the southern hemispheres. This means that he was the first author to present the hypothesis that the bipolar distribution of some taxa of marine organisms was due to deep-water migration (Andriashev 1978).

J. Hooker (1847), a member of Ross's expedition, investigated the plants that were collected during this expedition to the Antarctic, and he supported Ross's hypothesis by discovering some plant species in Patagonia, which were also known from Great Britain, but unknown in the tropics. Candolle (1855), in his Botanical Geography, also touched upon "des espèces disjointes" (species with disjunct distribution), referring to 32 species that were known from the temperate zones of both hemispheres. Dana (1854) pointed out the similarity, between New Zealand and Great Britain, in genera composition of Decapoda (Crustacea). In his opinion, the closeness (propinquity) effect of faunas in the temperate zones creates morphologically similar ("convergent appearance") species in areas with similar ecological conditions.

We emphasize that all pioneering investigations of bipolarity analysed the same species, or closely related species, from the temperate or subtropical zones of both hemispheres. These species had an interruption in their distribution pattern in the tropics. This, without doubt, allowed earlier biogeographers to equate the meaning of the notions "bipolar" and "antitropical" distribution, as also suggested by Kafanov \& Kudrjashov (2000).

Bergh (1920, 1936, 1947) devoted three research papers to this question and paid special attention to On the Origin of Species (Darwin 1859). Darwin showed that the same plant species (or subspecies) were found in Europe, southern Australia and New Zealand as in high-mountain areas of the tropics. These plants were typical for the temperate zones of both hemispheres, and were absent in the lowlands of the tropics. This conclusion of Darwin's was adopted as a fact by Bergh.

Bergh (1947: 128, 129) concluded that it should be possible to characterize the presence and distribution of "temperate forms" in the deep cold water of the tropical and subtropical zones as bipolar species. If it is possible to conclude that, from a biogeographer's point of view, bipolar and antitropical species distributions are quite different, then the bipolar distribution probably has an ecologicalbiogeographical significance, and the two concepts have different meanings. Bergh analysed all data known at his time about closely related species of the same genus that were known from the cold waters off New Zealand, South Africa and South America from the southern hemisphere (and from England, Norway and Kamchatka from the northern hemisphere), but which were absent in the shallow, warm-water areas of the tropical zone. He wrote: "this distinctive and enigmatic peculiarity of the geographic distribution was named bipolarity" (Bergh 1947: 128). This opinion by Bergh (1947: 131) applies mostly to "identical forms or subspecies, or close species" of water mammals or marine fishes, common for "the temperate latitudes of the North and South".

Derjugin (1915), in his Fauna of the Kola Bay and Conditions of its Life, included a chapter on "The theory of cosmopolitism and bipolarity", where the faunistic similarities of the "Arctic-Subarctic-boreal" and "Antarctic-Subantarctic-notal" zones were analysed. Here "the same or closely related species" were also found, but these were absent in the "tropical-subtropical waters". This chapter is rich in examples, many of which are without supporting data. However, with respect to some species, e.g. some hydroids, their status as "bipolar" is still valid (see below). 
The existence of bipolar species distributions is practically accepted by all biogeographers. Nevertheless, after more than 150 years, the bipolarity question continues to be discussed, and there are both supporters and opponents to whether this phenomenon is real or not. We will try to discuss the available points of view that we have come across concerning the explanation of the causes of this phenomenon.

The idea of bipolarity is discussed, argued and categorically rejected, due to either of the following two reasons:

1. Species are insufficiently identified (Thompson 1897-1898; Knudsen 1970; Pasternak 1973);

2. The comparison of faunas from different zones showed totally different assemblages (Ortmann 1896, partly; Dollo 1904; Stiasny 1934).

The idea of bipolarity is supported (only selected publications on taxonomy, faunistics and biogeography cited) by Ross (1847), Dana (1854), Theel (1886), Pfeffer (1891), Murray (1896), partly Ortmann (1897), Derjugin (1915), Bergh (1920, 1933, 1936, 1947), Zenkevitch (1948, 1960), Hubbs (1952, "antitropical", "bi-temperate" distribution), Ekman (1953), Hubbs et al. (1953), Vinogradova (1955, 1969, 1977), Vinogradov (1959, 1965), Birstein (1960, 1963), Andriashev (1964, 1965, 1987), Darlington (1965), Kussakin (1967), Petrushevskaya (1967, 1969a), Stepanjants (1967, 1979), Kruglikova (1969b, 1999), Stepanjants et al. (1996, 1997a), Beklemishev (1969), Mead (1970), Averintsev (1972), Brundin (1975), Hasle (1976), Dunbar (1979), Pierrot-Bults \& Van der Spoel (1979), Rass (1980), Semenov (1982), Es'kov (1984), Gruzov (1985), Briggs (1987), Van der Spoel (1991), Voronov et al. (2002) and others.

Below we have cited the most popular explanations of the bipolarity phenomenon (see also Table I). The definitions of these concepts are by no means accepted by all authors.

\section{Polytopic origin}

One of the first ideas on the independent origin of some identical species, "original local creations", was provided by Dana (1854), who pointed out the close environmental similarity, i.e. the cold or temperate conditions of oceanic waters on both hemispheres. Dana noted the presence of some genera within Decapoda (Crustacea), such as Cancer, Palaemon and others, and very similar species, such as Palaemon squilla (in Great Britain) and Palaemon affinis (in New Zealand) in both hemispheres. This allowed him to speak about identi- cal species of undetermined/independent origin (Stepanjants et al. 1996, 1997a).

\section{Convergent origin}

This hypothesis explains the independent origin of identical or closely related species in the temperate zones of both hemispheres as having evolved from warm-water or even tropical forms. The founder of this theory on the origin of bipolarity was Hesse (1924). He examined the distribution of the foraminifer genus Globigerina (Neogloboquadrina) and proposed Globigerina pachyderma as an example of a bipolar species. In his opinion there are in reality two identical species, both originating from the warmwater species Globigerina dutertrei under the temperate condition of both hemispheres, and both of these species are named Globigerina pachyderma. Darling et al. (2004) concluded, by molecular dating, that the northern Neogloboquadrina pachyderma (sin) small subunit (SSU) ribosomal genotype and the southern $N$. pachyderma (sin) SSU genotype separated about 1.8-1.5 Ma ago. This hypothesis has something in common with the opinions of Brinton (1962) and Beklemishev (1969): "the rule of homologous biotopes". This was defined earlier in connection with the mapping of medusae distribution (Maas 1897, 1906, 1909; Vanhöffen 1906), and is also discussed below in connection with the theory of bionomic bipolarity.

\section{Relict theory}

The earliest and most widely accepted theory among bipolarity supporters may be named the "relict theory". The founders of this theory were Theel (1886), Pfeffer (1891) and Murray (1896), who developed it from the concept of a universal distribution of marine fauna during the Tertiary. At this time, the climate was sufficiently warm and uniform all over the Earth, and species had a close to global distribution (Steuer 1910; Derjugin 1915; Bergh 1947). During later cold periods, the fauna living close to the poles either died or adapted to the cold waters on both hemispheres, and may be characterized as relict faunas (species). On the contrary, in the tropics, where intensive competition had developed, relict species did not adapt, and disappeared, while a new fauna evolved. Bergh (1947) categorically rejected this possibility. $\mathrm{He}$ argued that even before the Tertiary periods there were already strongly pronounced and clearly marked faunistic zones. However, the near-polar fauna had evolved as a result of changes in these environments, whereas the tropical fauna remained almost unchanged. Moreover, Bergh accepted the view by Derjugin (1915) 
Table I. Concepts of the origin of the bipolarity phenomenon.

\begin{tabular}{|c|c|c|c|}
\hline & Hypothesis & Author & Points of concepts \\
\hline 1. & Polytopic origin & Dana 1854 & $\begin{array}{l}\text { The independent origin of some identical species, "original local creations", where the environments are very similar, } \\
\text { i.e. low temperature conditions of the water masses in both hemispheres. }\end{array}$ \\
\hline 2. & Convergent origin & Hesse 1924 & $\begin{array}{l}\text { Independent origin of identical, or closely related species in the temperate zones of both hemispheres as having evolved } \\
\text { from warm-water or even tropical forms. }\end{array}$ \\
\hline 3. & Relict theory & $\begin{array}{l}\text { Theel } 1886 \text { Pfeffer } 1891 \\
\text { Murray } 1896 \text { Derjugin } 1915 \\
\text { Briggs } 1987\end{array}$ & $\begin{array}{l}\text { This concept developed from the idea of the universal distribution of marine fauna during the Tertiary, when the } \\
\text { climate was sufficiently warm and uniform all over the Earth, and species had an almost global distribution. During } \\
\text { the later colder (glacial) periods, the fauna living close to the poles either died, or became adapted to the cold waters in } \\
\text { both hemispheres, and may be characterized as relict fauna (species). In contrast, in the tropics, where intensive } \\
\text { competition had developed, the relict species did not adapt and disappeared and new fauna evolved. }\end{array}$ \\
\hline 3a. & $\begin{array}{l}\text { The replaced relict theory, a } \\
\text { modification of the relict theory }\end{array}$ & $\begin{array}{l}\text { Gepthner } 1936 \text { Darlington } \\
1965 \text { Es'kov } 1984\end{array}$ & $\begin{array}{l}\text { Concentrations of relict forms in extratropical areas are interpreted as specific relict reservations. The tropical zone, } \\
\text { therefore, is interpreted as the area where relatively young biota are formed. }\end{array}$ \\
\hline 4. & Contemporate migrations & Ortmann 1897 & $\begin{array}{l}\text { This phenomenon was explained as a result of modern migration by coastal or deep-water cold currents. The origin of } \\
\text { bipolarity by the migration theory now has wide support among classical faunists and modern biogeographers. }\end{array}$ \\
\hline 4a. & Anthropogenic transfer & $\begin{array}{l}\text { Theel } 1911 \text { Derjugin } 1915 \\
\text { Mileykovsky } 1977\end{array}$ & $\begin{array}{l}\text { Epibiotic fouling species are drifting along with macrophytes (see discussion below). This theory is applicable to } \\
\text { numerous planktonic organisms, including medusae, whose polyps are being distributed as foulings by drifting } \\
\text { substratum or ships. The same dispersal mechanism is also possible for species with a pelagic larvae stage. }\end{array}$ \\
\hline $4 \mathrm{~b}$. & Deep-water migrations & $\begin{array}{l}\text { Ross } 1847 \text { Bergh } 1947 \text { Birstein } \\
1963 \text { Vinogradov } 1968\end{array}$ & $\begin{array}{l}\text { Migration of pelagic cold-water species from one hemisphere to the other through meridional deep- and cold-water } \\
\text { currents. }\end{array}$ \\
\hline 5. & Glacial theory & Bergh 1947 & $\begin{array}{l}\text { Not only the Arctic and the temperate latitudes were affected by the Quaternary cooling during the glacial periods, but } \\
\text { the tropics too. During this time, some northern species penetrated into equatorial waters, and then finally inhabited } \\
\text { the southern hemisphere. When the temperature in the tropical regions rose again during post-glacial times, cold- } \\
\text { water species here either died or were forced to migrate northwards or southwards. }\end{array}$ \\
\hline 6. & Bionomic bipolarity concept & Andriashev 1986, 1987 & $\begin{array}{l}\text { The combined influence of closely related environmental factors creates conditions for the parallel development of } \\
\text { similar characters in unrelated species. These factors include low water temperature, sea-ice conditions, short } \\
\text { insolation periods for the hydrobionts, limited vegetative periods, all of which have a general influence on the character } \\
\text { of the reproductive processes, the prolonged embryogenesis, and low food specialization of the hydrobionts. This } \\
\text { concept showed independently that the origin of identical conditions, not only accounted for unrelated and } \\
\text { morphologically similar species, but for the development of the whole coenosis on both poles of the Earth. }\end{array}$ \\
\hline
\end{tabular}


who explained that bipolarity originated from cosmopolitism. It is appropriate to underline that hydroids (Cnidaria, Hydrozoa), based on their flexibility and their accordingly wide distribution, were presented by Derjugin as a group that is very suitable for the investigation of the bipolarity phenomenon. The examples given by Derjugin are convincing, as the species Filellum serpens, Lafoea dumosa, Halecium beani, Sertularella polyzonia $f$. gigantea (and others) are, according to Stepanjants et al. (1996)Stepanjants et al. (1997a)), transitional between cosmopolitan and bipolar species. Many of the radiolarian species listed in Appendix 1 seem to confirm the idea of bipolarity arising as a biogeography-/ecology-related phenomenon, and can be interpreted as having a transitional character between cosmopolitan and bipolar species. Examples of these species are, among others, Lithomitra lineata clevei, Lithomitra lineata arachnea, Cycladophora davisiana and Artostrobus annulatus (Petrushevskaya 1986; Kruglikova 1999).

Among twentieth-century biogeographers, the relict theory was supported by Briggs (1987), who analysed the latest views on the interrupted distribution of organisms ("antitropical disjunction"), such as "vicarianism", "hologenesis", "island integrations", and so on. He considered that the relict theory is defined and explained by the mechanism of "antitropical disjunction". Similar views were also expressed by Jarms \& Mühlenhardt-Siegl (1998), and their precursors (Crame 1974, 1996; Van der Spoel 1991; Dayton et al. 1997). However, Geptner (1936), Darlington (1965) and Es'kov (1984) had a slightly different explanation of this phenomenon. According to their theory, climatically stable tropical faunas migrated to the north and south of the tropics as a consequence of climatic changes, and these relict biotas outside the tropical regions are serving as "reservations" of extinct tropical faunas.

\section{Contemporary migrations}

Ortmann (1896) rejected the numerous examples in favour of the existence of the bipolarity phenomenon. However, he analysed the distribution of Decapoda (Crustacea) and found no bipolar species among them. He argued for the genera Crangon, Pandalus and Ponthophilus to be considered as bipolar.

Note here that a bipolar genus does not exclusively include bipolar species. Often a bipolar genus includes cold-water species distributed only in the northern hemisphere, and other cold-water species that are typical for the southern hemisphere, but with no other species having whatever other geographical distribution. As an example of this, the bipolar genus Gymnogonos (Cnidaria, Hydrozoa) includes Gymnogonos crassicornis from the deep Arctic and Gymnogonos ameriensis from the Antarctic regions, and no other species are included in this genus (Stepanjants and Svoboda, 2001).

Ortmann (1897: 581) found some species of Ponthophilus “... auf der nördlichen als auch auf der südlichen Halbkugel in den gemässigten und kalten Gegenden" ("... in the northern and southern hemisphere in temperate and cold regions"), whereas the other species of this genus inhabit the great depths in the tropical regions, and representatives of the genus Ponthophilus are not known from the shallow waters of the tropics (Ortmann 1897). These arguments allow us to define Pontophilus as a bipolar genus, if we follow Darwin's reasoning. Ortmann (1897) offers his own interpretation of the origin of bipolarity, and explains the phenomenon as a result of modern migration by coastal or deep-water cold currents. The origin of bipolarity by the migration theory has now a wide support among classical faunists and modern biogeographers. The distribution of different pelagic organisms, and their bipolar distribution, was confirmed for radiolarians (Popofsky 1908; Haecker 1908), pteropods (Meisenheimer 1905), and other groups, such as medusae, chaetognaths and many others (Chun 1897; Steuer 1910).

Anthropogenic transfer. Among hydroids, the migration theory is convincingly confirmed by the examples of epibiotic-attached species, which are drifting along with macrophytes (see discussion below). This theory is applicable to numerous planktonic organisms, including medusae, whose polyps are being distributed by attachment on drifting substrata, or in ballast tank water on ships. The same distribution mechanism is also possible for species with a pelagic larvae stage (Derjugin 1915; Mileykovsky 1977). According to Derjugin (1915), migrations by way of the larval stage are unlikely, as the larvae are very short lived (a few hours to some months). However, the displacement of suspended particles via the Gulf Stream from the Norwegian Sognefjord estuary to the Lofoten Islands takes only about a year (Helland-Hansen \& Nansen 1909). The warm Atlantic current (a branch of the Gulf Stream) needs about 1 year to pass through the Barents Sea (Rudels et al. 1994), giving room for about 12 radiolaria generations, each lasting about 36 days (Casey et al. 1971). Bjørklund \& Kruglikova (2003) concluded that the Arctic radiolarians are recruited from the Norwegian Sea, either through the Barents Sea or the Fram Strait. The warm Atlantic water takes about 11 years to reach the Lomonosov Ridge from the Fram Strait (Rudels et al. 1994), and as 
radiolarians are found in the Arctic Basins, they must live and reproduce in these water masses. Radiolarians were first introduced to the Arctic Basins not earlier than about 12,400 years bp (Bjørklund \& Kruglikova 2003). The self-sustaining Arctic Ocean radiolarian fauna originates from the Norwegian Sea. However, the Arctic Ocean radiolarian population is constantly being recruited from the inflowing Atlantic (Norwegian Sea) water, thus contributing to a renewal of genetic material for the species that can survive the harsh Arctic environments. Similarly, recent data on the settling time for the planulae of some hydroid species (Orlov 1994, 1996) show that it is impossible to exclude the possibility of migration through surface currents.

Deep-water migrations. The migration through deepwater currents is another way to explain a bipolar distribution whose origin can be considered as a selfsustaining system. This theory was first proposed, as an assumption, by Ross (1847), whereas Bergh (1947: 146) did not, in his discussion, exclude it as a possible mechanism. He proposed the typical example of the anglerfish (Lophius piscatorius), which is distributed in the North Atlantic to the south of the Azores and Cap Verde Islands, and in the South Atlantic to the north of Cape of Good Hope, living down to about $700 \mathrm{~m}$ depth. Bergh supposed that this species may be found at depth in the tropical zone of the Atlantic Ocean. However, in opposition to Ortmann (1897), he supposed that its migration would be from the northern to the southern hemisphere. Bergh (1947: 155), in an idiomatic style, wrote that "... the northerners are more active". The idea of a deep-water migration route was later supported by Birstein (1963). He wrote that the bipolar distribution, typical for some relict shallowwater species, remained after they disappeared from the surface waters, as deep-water progenies (offspring). Andriashev (1964, 1987) supposed that the distribution of some fish species in the families Zoarcidae and Liparidae had, without doubt, a Pacific origin. They migrated, according to his opinion, across deep-water masses along the western districts of North and South America to the Antarctic regions. Here they created a secondary centre of speciation, with a large number of not only species, but also genera. According to Andriashev's (1964, 1987) opinion, the bipolar species distribution of these fish families originated even earlier than the glacial Quaternary. This results in a specific shallowwater fauna into the notal and polar waters of the Southern Ocean. Vinogradov (1968) instead explained the penetration of pelagic cold-water species from one hemisphere to the other through meridional deep- and cold-water currents, the latter being intensified during periods of increased cold-water formation. Some other examples from other fossil groups are available in Boltovskoy (1994) and Boltovskoy et al. (1996).

\section{Glacial theory}

Bergh was one of the most prominent supporters of the bipolarity phenomenon. Most of the named theories were only partly accepted when Bergh (1933, 1947) developed his own general theory, the so-called "glacial theory". According to it, not only were the Arctic and temperate latitudes affected by the Quaternary cooling during the glacial periods, but the tropics too. During this time, some northern species penetrated into equatorial waters, and then finally inhabited the southern hemisphere. When the temperature in the tropical regions rose again during post-glacial times, the cold-water species there either died or were forced to migrate northwards or southwards. These species had also the possibility of occupying abyssal depths, just as the terrestrial plants of the high latitudes, as pointed out by Darwin, managed to penetrate the tropical highlands. As already stated, Bergh supposed that the distribution of species, as a rule, took place from north to south. The opposite penetration route (from south to north), however, applies for some fish species in the family Clupeidae (Svetovidov 1949) and Liparidae, genus Psednos (Andriashev 1993); most species of the families Trachymedusae and Narcomedusae (Van der Spoel \& Heyman 1983; Van der Spoel 1991); several hydroid species of the genus Monobrachium (Jarms \& Muhlenhardt-Siegl 1998), for some holothurian species of the genus Elpidia (Beljaev 1989), some radiolarian species, such as Lychnocanium grande (Campbell et Clark) rugosum Riedel, Artostrobus praetabulatus Petrushevskaya, Saturnalis circularis Haeckel, Pterocanium trilobum Haeckel and others (KrasheninNIkov et al. 1983; Kruglikova 1989b), and some diatom species such as Coscinodiscus marginatus Ehrenberg, Rhizosolenia barboi (Brun) and others (A. P. Jouse, pers. comm.).

A variant of this "glacial theory" is probably represented by the earlier named "theory of the shrinking relicts" (Es'kov 1984). According to this theory, some biota remained at their taxonomic and coenotic level as they followed the migrating water masses they were inhabiting, ending up to the north and south of an initial, climatically stable area. These water mass movements were induced by the major Quaternary climatic shifts from glacial to interglacial conditions and back again, and normally implied a north-south migration. The best example of this is in the North Atlantic, where the CLIMAP (Climate/Long Range Investigation Mapping and 
Predictions) (1976) project demonstrated that the polar front migrated from its present interglacial position in the Norwegian Sea to a position at about $45^{\circ} \mathrm{N}$ during the last glacial maximum. Since the establishment of a glaciated northern hemisphere (last $2.7 \mathrm{Ma}$ ), there have been at least 40 glacial periods (Mangerud 1992), indicating that major oceanic frontal systems have migrated, in a northsouth direction, more than 80 times. The CLIMAP project (1976) demonstrated that the Arctic faunal province drastically expanded during glacial periods, whereas the Subarctic and transitional faunal provinces shrank. The tropical faunal province also became restricted, but remained fairly stable. McIntyre (1967) pointed out that coccoliths showed that surface temperatures in the tropics during the last glaciation did not drop below $20^{\circ} \mathrm{C}$, which was also confirmed by the CLIMAP project (1976) results. This indicates that the temperature did not drop to a level permitting cold-water species to cross the tropics through surface currents, but a crossing via subsurface currents still remained possible. It is, however, still not known whether some radiolarian species established themselves as bipolar after the last glacial period, or in any earlier glacial periods. However, after the establishment of the northern hemisphere glaciation there are several examples of radiolarians with a bipolar distribution, as will be discussed later.

The term "bipolarity" ethymologically supposes a comparison of polar flora or fauna. However, the classical understanding of the phenomenon in question applies to polar, temperate and even subtropical areas, as far as distribution patterns are concerned. Bergh (1936: 35) wrote that some biogeographers affirm that ..."bipolarity consists in supposed similarity of Arctic and Antarctic faunas. As a rule there is no such similarity and there can't be, but there is similarity between faunistic or floristic elements of temperate latitudes of both hemispheres ...". Nevertheless, some investigators have the opinion that the "bipolarity" concept is only valid for Arctic and Antarctic biotas, and only seldom does anybody include boreal and notal distribution patterns in this definition. Hubbs (1952) suggested not using the term bipolar, and using antitropical instead, as most species described as bipolar are usually found at low and moderate latitudes, but not in the tropics, rather than at high latitudes. This kind of limitation is probably a result of ignorance, by many faunists and taxonomists, of the enormous body of literature devoted to this question. Apart from the abovementioned works, it is sufficient to mention the following monographs on radiolarians (Petrushevskaya 1967), hydroids (Stepanjants 1979), polychaetes (Averintsev 1972) and isopods (Kussakin
1967). General questions of marine biogeography were approached by Semenov (1982: 193), who proposed an original scheme of the latitudinal/zonal nomenclature of species distribution, and named as bipolar a "... distribution in the cold waters of the Arctic and Antarctic". This was largely accepted by several contemporary faunists (Pierrot-Bults \& Van der Spoel 1979; Jarms \& Mühlenhardt-Siegl 1998) and biogeographers (Dunbar 1979: 116). The last author considered bipolarity as "the presence in the Arctic and the Antarctic of apparently identical species without their presence in the intervening temperate and tropical regions".

During the second half of the twentieth century, "bionomic bipolarity", a new aspect of the bipolarity concept, was developed and defined by Andriashev (1986, 1987). Only true polar biotas were investigated in his analysis. Andriashev (1987: 65) considered himself as the follower of Zenkevitch on this question. In his opinion, the "bionomic bipolarity" is a particular case of Zenkevitch's concept of "longitudinal symmetry of the biologic structure in the Ocean" (Zenkevitch 1948). Nevertheless, Andriashev's "bionomic bipolarity" concept is based on the interpretation of Bergh (1977), suggesting that the geographical landscape has a transforming and selecting influence on the organisms. As a matter of fact, the question is centred on the similarity of abiotic factors in different environments. In this sense, the close environmental characters of the polar regions are especially significant. The combined influence of closely related environmental factors creates conditions for the parallel development of similar characters in unrelated species. These factors include low water temperature, sea-ice conditions, short isolation period for the hydrobionts, and limited vegetative period, all of which have a general influence on the character of the reproductive processes, the prolonged embryogenesis, and low food specialization of the hydrobionts. Andriashev (1987) developed the concept proposed by Bergh (1977) and showed independently that the origin of identical conditions, accounted not only for unrelated and morphologically similar species, but for the development of the whole biocoenosis on both poles of the Earth.

The origin of the cryopelagic communities, taxocoenosis and some species with similar morphological characters (Andriashev 1967, 1970, 1978) is more illustrative in this sense. Some adaptive biological characters were found for the first time in Arctic (Rass 1941; Andriashev et al. 1980) and Antarctic fishes (Andriashev 1964; White 1977; White \& North 1985). A specific organic substance having antifreeze properties was found in their blood, a fact of special significance (DeVries 1970; DeVries \& Lin 
1977; Schneppenheim \& Theede 1982; Andriashev 1986, 1987). This specific morpho-ecological category of fishes, characterized by active swimming, a permanent life in water temperatures close to freezing, and a permanent contact with pack ice, was named "cryopelagic" (Eastman \& De Vries 1985; Andriashev 1987). In the Arctic, this phenomenon occurs mainly in codfish (family Gadidae), whereas in the Antarctic it has been observed in the genus Pagothenia (family Nototheniidae). Apart from the cryopelagic fish species already mentioned, cryopelagic ichthyocoenosis and biocoenosis of fishes and invertebrates were described and investigated in both the Arctic (McGinitie 1955; Barnard 1959; Golikov \& Averintsev 1977; Mel'nikov 1980, 1989) and the Antarctic (Gruzov et al. 1967; Andriashev 1967). The similarity of the species composition, as well as the biocoenosis composition, in the two polar regions has been studied previously (Ushakov 1958; Andriashev 1987; Svoboda et al. 1995; Stepanjants et al. 2004).

It is interesting to analyse the origin of bionomic bipolarity, due to its implications for the epigenetic theory of evolution. This theory assumes that in some isolated ecosystems, such as islands, lakes, and other very special ecological niches (e.g. cryopelagic biocoenoses), evolution proceeds quicker than usual, and in this way new forms arise by speciation (Schwarz 1980; Levushkin 1982; Rasnitzin 1987).

According to the position of "adaptive compromise" (Rasnitzin 2002), there is some contradiction in these systems between the environmental situation and the necessity of some organisms to adapt to these environments. If these organisms do not adapt quickly (compromise) to their new environments, they are simply eliminated (extinct). We may therefore conclude that in this situation of an "adaptive compromise" new forms (species) may develop. Moreover, these forms may be similar (although not obviously related) in similar environments.

The current view on the peculiar bipolar distribution for some foraminifera species is that it is caused by genetic exchange of the same subpolar Arctic and Antarctic species (Darling et al. 2000; Norris \& De Vargas 2000).

After having concluded the historical survey of the bipolarity concept and its evolution, in addition to the different opinions and approaches to the problem, it is now possible for us to offer a new definition of bipolarity.

\section{New definition of the bipolarity phenomenon}

Bipolarity is the wide distribution of either the same, or closely related, or even unrelated taxa at the species and higher taxonomic levels, of flora and fauna having similar morphological characters, and inhabiting similar environments of the cold zones or cold waters of both hemispheres.

We have two distribution patterns that we can describe as being bipolar. The first includes representatives of bipolar taxa that are found in the polar and temperate zones of the World Ocean only, but are missing in the tropics, being characterized by a complexity of environmental conditions (bipolarity type 1, Figure 1). However, some bipolar species may also be found in subtropical and even in tropical zones, but then at greater depths. These migrating species follow the paths of water masses of polar origin with low temperatures and other adequate and closely similar environmental conditions. These marine organisms that are supposed to be "bipolar", but are also found at greater depths in the tropical zones, are described as "bipolar species with an equatorial submergence" (bipolarity type 2, Figure 1). In other words, "bipolarity" is not a clear biogeographical concept based on distribution only, but it is better treated as a biogeographical-ecological phenomenon. We believe that the terms "antitropical" and "bipolar" distribution are different, as the former is a typical biogeographical term, applied to species that are totally absent in the tropics, i.e. a synonym of "interrupted" or "disjunct" distribution. Contrary to an antitropical distribution, a species' bipolar (type 2) distribution would, if plotted on a map, include points in the tropics too, and their occurrence in this zone would be proof of their transport to the tropics by water of supbolar origin (Bogorov 1946). According to Beklemishev (1969), the centre of distribution of these species is situated in Arctic, high-boreal, notal and Antarctic waters, whereas their "expatriation zone" (the periphery of their distribution) is located in the deep cold waters of the tropics. We stress once again how this means that bipolarity (regardless of type) is not only a biogeographical term, but at the same time an ecological phenomenon. The distribution of the type 2 species on a map seems to be cosmopolitan, and therefore, from a biogeographical/ecological point of view, we may classify them as "species with bipolar/cosmopolitan distribution".

\section{Peculiarities of the bipolar distribution of radiolarians}

In this paper we consider the protist group "Radiolaria", which has the following higher taxonomic ranking: class Euradiolaria Lameere, 1931, which includes the superorder Phaeodaria Haeckel, 1879 and the superorder Polycystina Ehrenberg, 1838. 


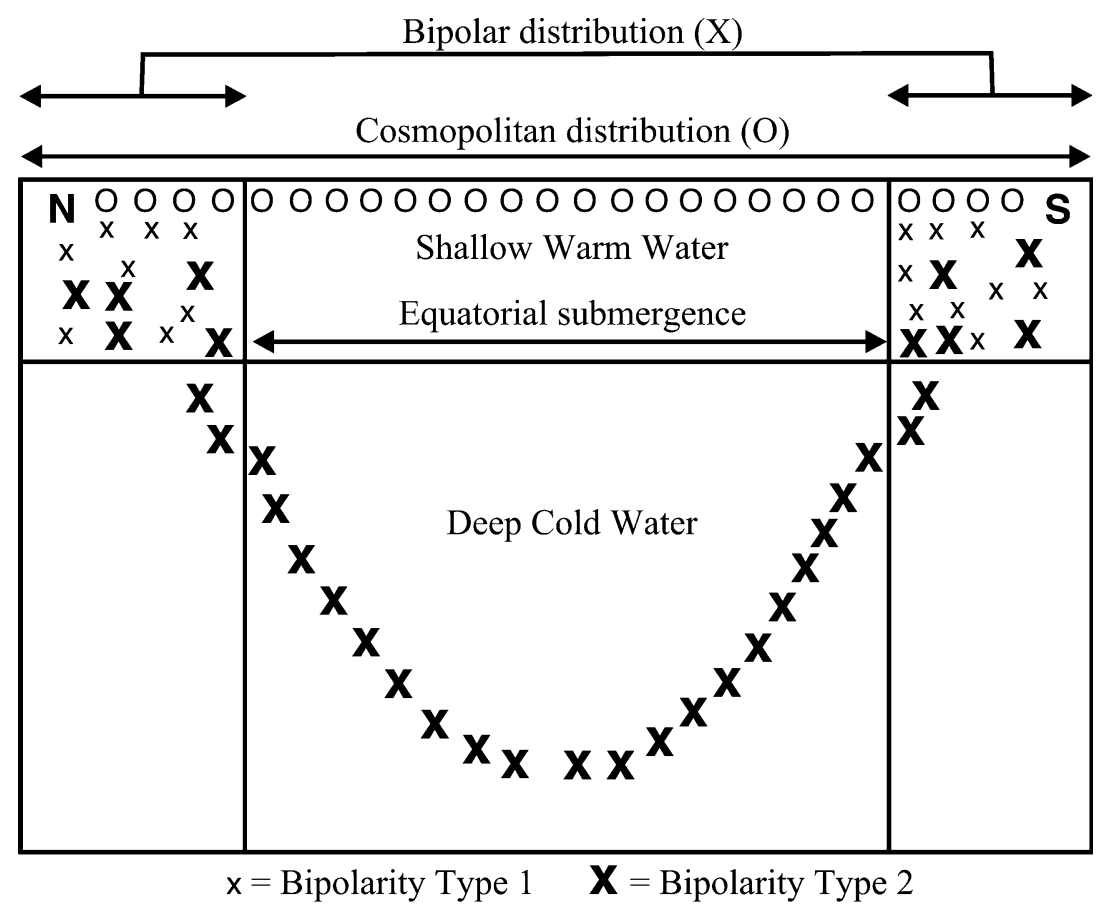

Figure 1. Schematic illustration of cosmopolitan and bipolar distribution types.

Within the latter, the orders Spumellaria and Nassellaria are found, as proposed by Ehrenberg (1875) and later supported by Petrushevskaya (1984, 1986), Petrushevskaya et al. (1976) and Cachon et al. (1990). Herein we do not discuss the protist group Acantharia Müller, 1855, as many taxonomists regard it to be a separate group, at the same taxonomic level as Euradiolaria (Levine et al. 1980; Reshetnjak 1981; Page 1984).

Investigations of peculiar radiolarian distribution patterns have now become possible due to a higher accuracy in the identification of species by contemporary taxonomists. Goll \& Merinfeld (1979) calculated the number of described species of living and fossil radiolarians, and proposed species counts of more than 600 for the Phaeodaria, and a far higher but uncertain number, perhaps more than 1500, for present and extinct Polycystina. Recently De Wever et al. (2001) wrote that probably more than 8000 species of polycystine radiolarians, grouped into nearly 2500 genera, are distributed throughout the fossil record. They also surveyed all available sediment trap and haul studies, reporting a total of 269 nassellarian and 210 spumellarian species known from the Arctic, tropical, and Antarctic domains. The number of radiolarian species may be slightly lower, not only due to unwarranted splitting, but most importantly by the limited knowledge we have of both the ontogeny and the geographical distribution of most radiolarian species. The absence of knowledge of the juvenile stages of radiolarians, and of their geographical variability both lead to unjus- tified descriptions of a multitude of new species. This particularly applies to authors who only investigated restricted areas, and did not pay attention to the distribution and morphological similarities or differences in species from different regions.

Today we have knowledge about radiolarian faunas from practically all regions of the World Ocean. The presence of large collections of radiolarians personally allows authors to ascertain the validity of the species that are included in published species lists. It should be emphasized that in standard plankton samples (plankton net with a mesh size of $125 \mu \mathrm{m}$ or larger) the representatives of the Polycystina are very rare or even missing, and therefore seldom identified and presented in faunal lists. Phaeodaria tests are considerably larger and, as a rule, almost all phaeodarian species are reported in plankton samples, even if some particularly fragile taxa may be present only as fragments. During the last decades, sediment trap studies have provided important information on radiolarian species composition and living depths, but so far such results are only available from a few scattered points in the World Ocean. Another, and probably more reliable, way to study the polycystine radiolarian fauna, is to investigate the large collections of bottom sediments from the World Ocean. Sedimentary material (box, gravity and piston cores, as well as grab samples) from the deep ocean bottom from a large number of stations began to accumulate during the 1950s in different core libraries in many countries. Since the late 1960s, geological investigations based on drilling 
of the deep oceans (Deep Sea Drilling Project, Ocean Drilling Program, Integrated Ocean Drilling Program) regularly recovered complete sedimentary sections, from the oceanic basement to the sediment surface, from different regions of the World Ocean. This allows us to study the distribution of radiolarians in both time and space.

For the work on bipolarity of radiolarians we have used a large number of taxonomic and faunistic publications, from the old classical to the most recent (Bailey 1856; Ehrenberg 1862, 1872; Haeckel 1862, 1881, 1887; Brandt 1895; Cleve 1899, 1900, 1901; Jørgensen 1900, 1905; Borgert 1901; Popofsky 1904, 1908, 1913; Haecker 1908; Dogiel \& Reshetnjak 1952; Reshetnjak 1955, 1966, 1981; Riedel 1958, 1971; Hülsemann 1963; Hays 1965; Petrushevskaya 1966, 1969a,b, 1971, 1972, 1977, 1979, 1981, 1986; Nigrini 1967, 1970, 1971; Kruglikova 1969a,b，1975，1977，1988，1989a,b, 1995, 1999; Riedel \& Sanfilippo 1970, 1971; Beers \& Steward 1971; Casey et al. 1971; Ling et al. 1971; Kling 1973, 1976, 1977; Ling 1974; Bjørklund 1974, 1976, 1984; Chen 1975; Renz 1976; Weaver 1976; Johnson \& Nigrini 1980, 1982; Takahashi \& Honjo 1981; Stanley 1981; Nakaseko \& Nishimura 1982; Blueford 1983; Bjørklund \& Goll 1984; Riedel et al. 1985; Matul 1989, 1990, 1991, 1997; Takahashi 1991; Abelmann 1992a,b; Boltovskoy et al. 1993, 1996; Cortese \& Bjørklund 1996; Abelmann \& Gowing 1997; Nishimura et al. 1997; Bjørklund \& Kruglikova 1998, 2003; Bjørklund et al. 1998; Dolven \& Bjørklund 2001; Kruglikova \& Bjørklund 2001; Matul et al. 2002; Cortese unpublished).

At the beginning of these investigations on the (palaeo)biogeography of radiolarians, the authors had many hundreds of samples of recent plankton available, as well as a great amount of Palaeocene to Holocene bottom sediment cores from different regions of the World Ocean. These included the Greenland and Norwegian Seas, the shallow waters north of Iceland, the Norwegian fjords, the shallow Eurasian Arctic seas, the high-latitude basins of the Arctic Ocean, different regions of the Atlantic, Indian and Pacific Oceans, including the tropical (equatorial) zone, the Russian Far East seas, and finally the Atlantic, Indian and Pacific sectors of the Antarctic.

By summarizing the available literature and including our own original data, it is now possible to evaluate and estimate the number of radiolarian species inhabiting the different areas (zones) of the World Ocean. The cold-water provinces, i.e. waters with temperatures from -2 to $+13^{\circ} \mathrm{C}$ based on data from Petrushevskaya $(1971,1986)$, are of special interest to us.
Our data suggest that about 70 polycystine radiolarian species are distributed in the Arctic Basin (Bjørklund \& Kruglikova 2003), and about 100 species are known from the Okhotsk Sea (Kruglikova 1975, 1999). A little more than 80 species were identified in the Bering Sea (Blueford 1983) and about 200 species are present in the Arctic-boreal zone of the Pacific Ocean (Kruglikova 1999). In the Norwegian Sea, including the Iceland and Greenland Seas, 105 species have been identified (Bjørklund et al. 1998), whereas more than 100 species comprise the radiolarian assemblage in the Antarctic (Petrushevskaya 1966; Abelmann, pers. comm.). According to Petrushevskaya (1986: 82), radiolarians originated in the tropics, and therefore most of the species are found in warm waters, inhabiting the subsurface levels from 50 to $500 \mathrm{~m}$ of the tropical zone. Although it is still unclear whether this theory of a low-latitude origin for radiolarians is true, it is evident that this group is more diversified in the tropics than at the poles. Obviously all these species have not been analysed in the scope of this article.

The list of radiolarian species in Appendix 1 includes those taxa whose geographical distribution, according to our understanding, may be classified as bipolar. To understand the rationale behind the classification of each species as displaying a bipolar distribution, we provide information on the distribution of each species in the northern and southern hemispheres. From this list it appears that 46 species of Phaeodaria, Spumellaria and Nassellaria are in accordance with our definition of bipolar species. The reader should notice that at present we may suggest a bipolar distribution pattern within radiolarians at the species level mostly. However, bipolarity may also occur in three radiolarian genera (i.e. some, but not necessarily all, of the species belonging to each genus have a bipolar distribution), as Petrushevskaya (1981) proposed that the genera Dumetum Popofsky, 1913 and Protoscenium Jørgensen, 1905 have bipolar distributions, and we propose herein the same for the genus Botryocampe Ehrenberg, 1860 emended Petrushevskaya (1975). So far we have not observed any bipolarity at family or higher levels because the taxonomy of these higher rank Radiolaria/Polycystina has not yet been satisfactorily revised. Synonymy issues at the genus level can occasionally cause the grouping of up to eight previous genera. As an example, in the works of Petrushevskaya (arguably the best present-day taxonomist) Cycladophora davisiana has been reported as: Theocalyptra, Cycladophora, Eucecryphalus, Diplocyclas, and in other works it has also been assigned to Eucyrtidium, Stichopilium, Pterocodon and Pterocanium. Bjørklund (1976) combined the genera Echinomma, Actinomma, Cromyomma and Cromyechinus 
in the single genus Actinomma. Thus, at this stage we limit our discussion to the bipolarity of radiolarian species whose taxonomy is more or less confidently known to us.

The species Sethopilium meunieri Schröder, 1914 (Appendix 1, 27; Figure 2) has a distribution that fully satisfies the original meaning of the word "bipolarity", as this species is known from the highest Arctic (Meunier 1910; Schröder 1914; Bjørklund \& Kruglikova 2003), and from the glacial Antarctic zone (Petrushevskaya 1977). Single occurrences of this species are reported from the Kara Sea and in the central polar basin. Here conditions are similar to "the glacial subregion" of the southern hemisphere (Antarctic Atlas 1966), indicating the possibility that similar species appear in special (extreme) ice conditions (see discussions above and below).

At present, distribution data are available for the following species in the Arctic and high-boreal waters of the Atlantic and Pacific Oceans, or only in the Pacific:

Phaeodaria: Aulacantha laevissima Haeckel, 1887 (Appendix 1, 1); Aulastrum spinosum Borgert, 1901 (Appendix 1, 5) (Figure 2); Sagenoscena irmingeriana Borgert, 1901 (Appendix 1, 8, absent in the Arctic); Coelographis antarcticus Haecker, 1908 (Appendix 1, 9).
Spumellaria: Actinomma boreale Cleve, 1899 (Appendix 1, 10); Actinomma l. leptoderma (Jørgensen, 1900) (Appendix 1, 11); Actinomma l. longispina Cortese \& Bjørklund, 1998 (Appendix 1, 12); Rhizoplegma boreale (Cleve, 1899) (Appendix 1, 15); Prunopyle? antarctica Dreyer, 1889 (Appendix 1, 16); Spongurus pylomaticus Riedel, 1958 (Appendix 1, 19); Stylodictya aculeata Jørgensen, 1905 (Appendix 1, 21); Stylochlamydium venustum (Bailey, 1856) (Appendix 1, 22).

Nassellaria: Protoscenium simplex (Cleve, 1899) (Appendix 1, 26), Pseudodictyophimus gracilipes (Bailey, 1856) bicornis (Ehrenberg, 1861) (Appendix 1, 29), Lophophaena clevei Petrushevskaya, 1971 (Appendix 1, 31); Phormacantha hystrix Jørgensen, 1905 (Appendix 1, 32), Plectacantha oikiskos Jørgensen, 1900 (Appendix 1, 33); Mitrocalpsis araneafera Popofsky, 1908 (Appendix 1, 34); Sethoconus tabulatus Ehrenberg, 1872 (Appendix 1, 35); Androcyclas gamphonycha (Jørgensen, 1900) (Appendix 1, 44) and Botryocampe inflata (Bailey, 1856) (Appendix 1, 46). These species are found similarly in the "glacial subregion" of the Antarctic. This distribution pattern is referred to as bipolarity type 1 (Figure 1).

The distribution of five additional phaeodarian species can also be considered bipolar, but with some restrictions, as no conclusive data about their vertical distribution are available. So far they have

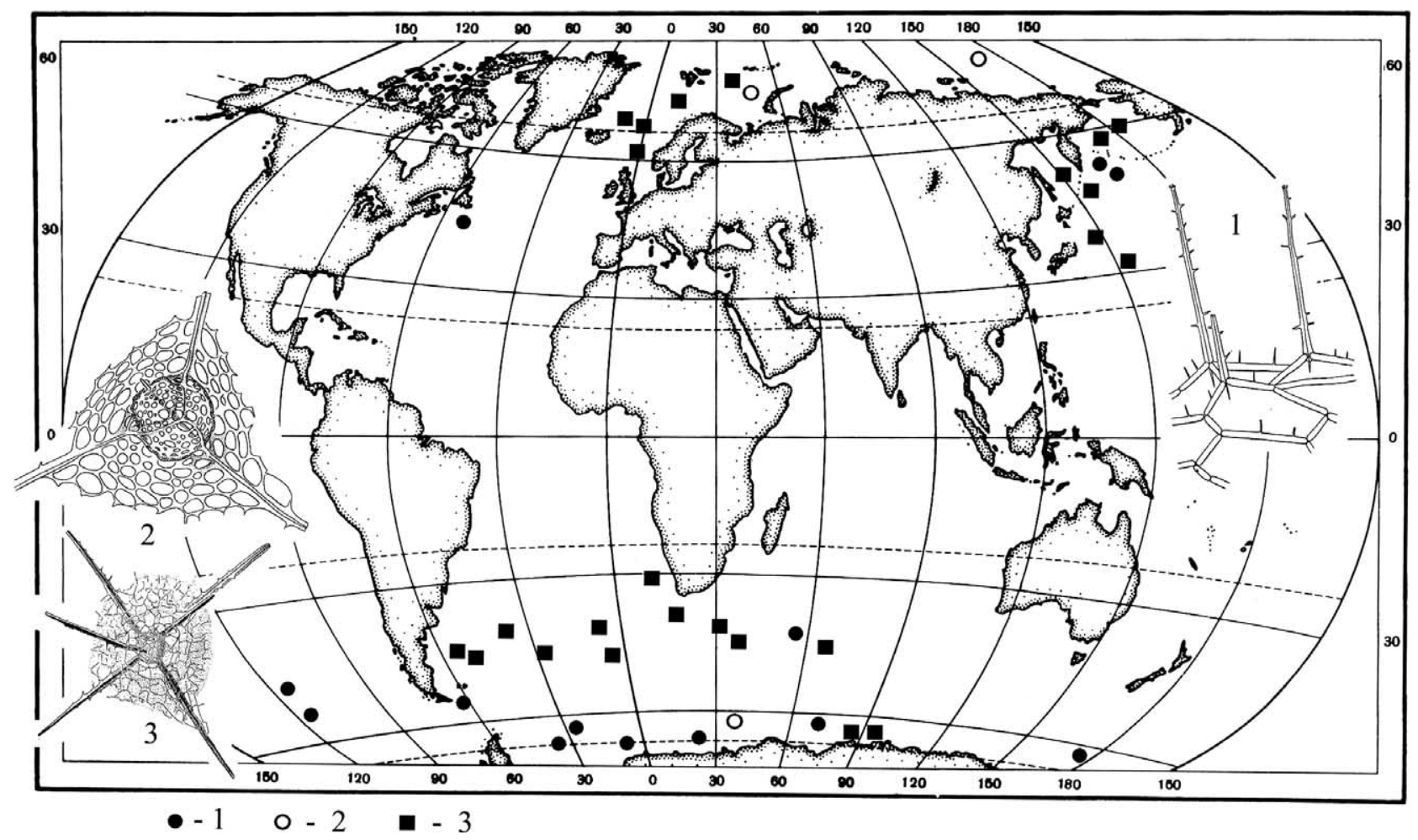

Figure 2. The bipolar distribution of three radiolarian species. The numbers in parentheses refer to the species numbers in Appendix 1. 1, Aulastrum spinosum Borgert, 1901 (no. 5); 2, Sethopylium meunieri Schroeder, 1914 (no. 27); 3, Rhizoplegma boreale (Cleve, 1899) (no. 15). 
only been found at subsurface, bathyal and even abyssal depths of the ocean, and there are no data indicating whether these species also exist in surface waters. These species are: Aulodendron verticillatum Haecker, 1908 (Appendix 1, 2; 500-3420 m); Auloceros arborescens irregularis (Appendix 1, 3; 0$8500 \mathrm{~m})$; Aulographonium antarcticum Haecker, 1908 (Appendix 1，4; 0-8500 m); Castanidium inclinatum Reshetnjak, 1952 (Appendix 1, 7; 0$4000 \mathrm{~m}$ ). The distribution of Castanura primitiva Reshetnjak, 1952 (Appendix 1, 6; 4000-8000 m) is particularly interesting, as this species has only been found at abyssal depths in the boreal Pacific and in the "glacial" subregion of the Antarctic. In spite of the opinion that no characteristic radiolarians could be found at depths $>4000 \mathrm{~m}$ (Vinogradov 1968: 175), data by Dogiel \& Reshetnjak (1952) indicate that Castanura primitiva occurs only at depths $>4000 \mathrm{~m}$, and may be considered, probably only in the Pacific, as a typical deep-water bipolar species.

Representatives of Spongurus pylomaticus (Riedel, 1958) (Appendix 1, 19) and Stylochlamydium venustum (Bailey, 1856) (Appendix 1, 22) are remarkably different morphologically in the northern and southern hemispheres (Kruglikova 1969b, 1974, 1977). The former was described from the Antarctic. Its test has an upper loose layer ("mantle") that grows on a massive spongy part, and covers the test completely. In the Arctic-boreal province of the Pacific, juvenile stages of Spongurus pylomaticus resemble a solid, spongy bow-tie. The mantle begins to grow from the middle, and gradually moves towards the ends of the test. During the earliest juvenile stages, the mantle looks like a narrow belt around a "waist". The species from the North Pacific was described as Spongurus pylomaticus borealis (Kruglikova 1974, 1977). Stylochlamidium venustum from the North Pacific differs from the Antarctic species by its more convex and lenticular shape. Plates covering the spiral central part of the skeleton are more easily seen on it compared with the Antarctic forms (Petrushevskaya 1967; Kruglikova 1969a,b, 1974, 1977). Nevertheless, each of them is regarded as the same species in both hemispheres. This case of bionomical or ecological bipolarity represents an example of closely related species with very similar characters, as they originated independently under the influence of very special conditions. The stratigraphic and regional distribution of a few species was studied by Stanley (1981). On the basis of her data, Actinomma delicatulum (Dogiel, 1952) (Appendix 1, 14) and Spongurus pylomaticus had a northern and southern population that separated before the glacial onset. No specimens of these taxa have been found at equatorial and low latitudes since the Late Miocene and the timing of their separation is unknown.

The following six Spumellaria species are bipolar: Actinomma popofskii (Petrushevskaya, 1967) (Appendix 1, 13), Actinomma delicatulum (Dogiel, 1952) (Appendix 1, 14), Prunopyle? tetrapila Hays, 1965 (Appendix 1, 17), Stylatractus pyriformis (Bailey, 1856) (Appendix 1, 18), Stylodictya stellata Bailey, 1856 validispina Jørgensen, 1905 (Appendix 1, 20), Spongotrochus glacialis Popofsky, 1908 (Appendix 1, 23; Figure 3).

The following 13 Nassellaria species are also bipolar: Enneaphormis rotula Haeckel, 1881 (Appendix 1, 24), Enneaphormis enneastrum Haeckel, 1887 (Appendix 1, 25); Pseudodictyophimus gracilipes gracilipes (Bailey, 1856) (Appendix 1, 28); Ceratocyrtis histricosa (Jørgensen, 1905) (Appendix 1, 30); Artostrobus annulatus (Bailey, 1856) (Appendix 1, 36); Artostrobus joergenseni Petrushevskaya, 1967 (Appendix 1, 37); Lithomitra lineata clevei Petrushevskaya, 1974 (Appendix 1, 38); Lithomitra lineata arachnea (Ehrenberg, 1862) (Appendix 1, 39; Figure 3); Cycladophora davisiana davisiana Ehrenberg, 1862 (Appendix 1, 40); Cycladophora d. cornutoides (Petrushevskaya, 1967) (Appendix 1, 41); Dictyocephalus hirundo (Haeckel, 1887) (Appendix 1, 42); Corocalyptra craspedota (Jørgensen, 1900) (Appendix 1, 43); and Artobotrys borealis (Cleve, 1899) (Appendix $1,45)$.

The species listed in the two paragraphs above have a very wide distribution area and the borders between them are limited by similar ecological parameters. Distribution plots for these species reveal that they are found in practically all zones of the World Ocean, including the tropics. Due to their ecological requirements, their distribution depths in different oceanic zones are also different. In other words, these migrating species follow the paths of water masses having low temperatures and other adequate environmental conditions (see the concept of latitudinal vertical submergence: Haecker 1908; Reshetnjak 1965), and they are therefore good examples of the above-defined bipolar distribution (bipolarity type 2, Figure 1).

At present we do not know the reasons and time for the development of bipolar species distribution. Stanley (1981), in her thesis, discussed several very interesting aspects of bipolarity in the genera Prunopyle and Sphaeropyle. There is a series of taxonomic problems that would have been worth discussing in greater detail here, but this is outside the scope of this paper. However, the four species in question are namely: Prunopyle antarctica Dreyer, 1889 (Appendix 1, 16) and Prunopyle tetrapila Hays, 1965 (Appendix 1, 17), both of which are common in the southern hemisphere in the Pacific, Atlantic and 


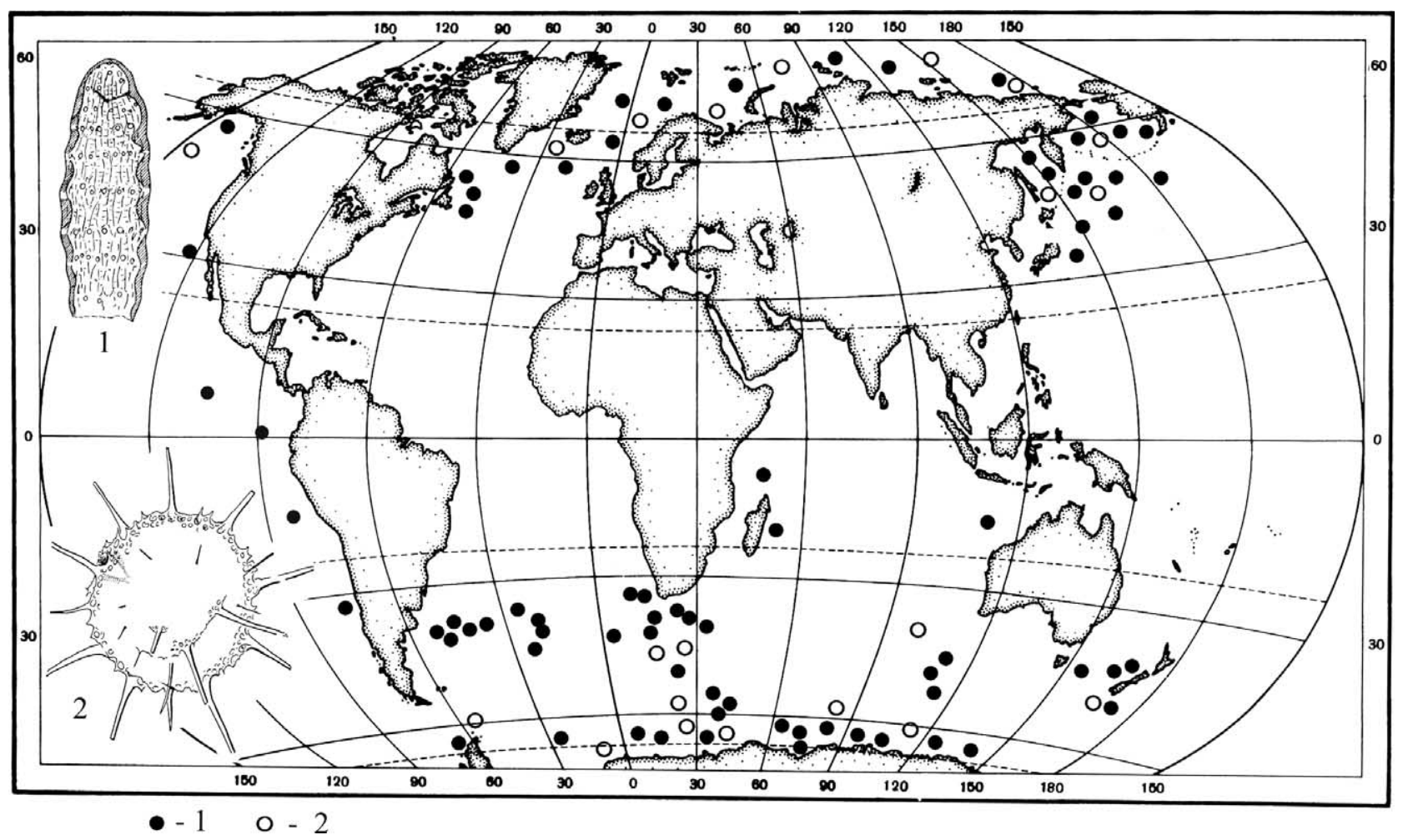

Figure 3. The bipolar distribution of two radiolarian species. The numbers in parentheses refer to the species numbers in Appendix 1. 1, Lithomitra lineata arachnea (Ehrenberg, 1862) (no. 39); 2, Spongotrochus glacialis Popofsky, 1908 (no. 23).

Indian sectors of the Southern Ocean, and Sphaeropyle langii Dreyer, 1889 and Sphaeropyle robusta Kling, 1973 are both common in the northern hemisphere in the Pacific Ocean. But Stanley (1981) found Prunopyle tetrapila in drilling material in the tropics (at DSDP Site 77) and concluded that this is a cosmopolitan form. Kling (1973) kept Prunopyle antarctica as a synonym of Sphaeropyle langii and preferred to use Sphaeropyle langii. The same taxonomic interpretation was made by Stanley (1981), who synonymized Sphaeropyle langii with Prunopyle antarctica. Petrushevskaya (1975) pointed out the possibility that Prunopyle tetrapila and Sphaeropyle robusta are conspecific, and Stanley (1981) also synonymized Sphaeropyle robusta with Prunopyle tetrapila.

We agree with Petrushevskaya (1975) and Stanley (1981) that Prunopyle tetrapila and Sphaeropyle robusta are conspecific. However, we do not fully agree with the conclusion of Kling (1973), Petrushevskaya (1975) and Stanley (1981) that Prunopyle antarctica and Sphaeropyle langii should be synonymized. We think these two forms are different and can be identified and recognized as species or subspecies in both hemispheres and therefore exhibit a bipolar distribution. For the time being we recognize the following three morphotypes: Prunopyle? langii, Prunopyle? tetrapila and Prunopyle? antarctica, the first one with only a northern distribution, whereas the two latter ones have both a northern (Subarctic) and southern (Antarctic) distribution, i.e. the same species at both hemispheres. At this stage we have some doubt about which genus these species belong in but they should definitely be in the same genus. We include all these forms within the genus Prunopyle(?). In fact, the genus Sphaeropyle is artificial, as any form with an incomplete outer sphere (the so-called pylome) can fit its definition. Dreyer (1889), who first proposed the genus, included species with two, three and four spheres, which is a highly artificial practice, and has nothing to do with natural relationships. But we have now arrived at a slightly different interpretation and understanding of their relationship to other actinommids. Petrushevskaya (1967) placed Sphaeropyle antarctica in the genus Cromyechinus and later transferred this species to the genus Actinomma (Petrushevskaya, 1975) (a move that we strongly support). This is beyond the scope of this paper, but we will point out the fact that Actinomma boreale Cleve, Actinomma leptoderma (Jørgensen), and Prunopyle(?) antarctica (our Appendix 1) are three species with very similar skeletal morphology, but all three show a bipolar distribution. This is based on the new material that is now available to us (study in progress). A revision of these genera and species is needed to fully understand their relationship. 
Our attempt was to answer the question: what were the reasons for, and when did the bipolar species obtain their present disjunct distribution? We may get some answers from palaeontological data. Prunopyle tetrapila was reported by Kling (1973) to be extinct in the Pliocene (ca. $1.85 \mathrm{Ma}$ ), close to the Pleistocene boundary, but Stanley (1981) extended the extinction to close to $1 \mathrm{Ma}$. In the Antarctic, Hays (1965) reported Prunopyle tetrapila to be extinct in the lower Pleistocene at ca. 0.7 Ma. Stanley (1981) found Prunopyle tetrapila to be extinct at ca. 1.6 Ma in the tropics, at DSDP Site 77 , and concluded that it was a cosmopolitan form prior to $1.6 \mathrm{Ma}$, but had a disjunct or bipolar distribution after 1.6 Ma.

Motoyama's (1997) data can also be used to explain this phenomenon. Cycladophora davisiana davisiana first occurred in the Northwest Pacific at 4.2 Ma, and rapidly increased in abundance at 2.7 Ma. This is the time when the northern hemisphere glaciation started, a timing that is well documented in the North Atlantic (Jansen et al. 1989) and in the North Pacific (Haug et al. 2005). During the Early Pleistocene, Cycladophora davisiana davisiana had a cosmopolitan distribution, but at about $1 \mathrm{Ma}$ it became common at high latitudes in both hemispheres, whereas at low latitudes it only occurred in low numbers, as is also the case today.

Cycladophora davisiana davisiana is the only species, for the time being, that we can demonstrate having a distribution pattern associated with glacial events, as this taxon had an abundance increase at the onset of northern hemisphere glaciation at 2.7 $\mathrm{Ma}$ and became common at high latitudes in the time interval (1.2-0.9 Ma) when Pleistocene glaciations were changing from a 41 to a 100 ka cycle. Cycladophora davisiana davisiana evolved first in the northern hemisphere and then, as suggested by Motoyama (1997), it migrated from the north to other oceans, again an example supporting the glacial theory of Bergh (1947).

In summary, radiolarians do not provide conclusive evidence of which theory better explains the mechanism behind the present-day bipolar distribution of some taxa. Another aspect relevant to the interpretation of the proposed evolutionary changes and, more generally, the contribution of radiolarians to bipolarity theories, concerns the chronology used in Stanley (1981). This was based on Berggren's timescale (Berggren 1972; Haq et al. 1977), where the Pliocene/Pleistocene boundary is dated at 1.6 $\mathrm{Ma}$, and is supposed to represent the onset of rapid glacial/interglacial oscillations (Keany \& Kennett 1972). This is not correct as oxygen isotope stratigraphy and ice rafted detritus records from the North Atlantic suggest that the strengthening of the northern hemisphere glaciation took place at about 2.7 Ma (Jansen et al. 1989). Between 2.7 and ca. 1.2 Ma, glacial oscillations had a period of $41 \mathrm{ka}$ (short-lasting glacials of small amplitude), but since ca. 0.9 Ma the well-known 100 ka oscillations (long glacials of large amplitude) became established. One could speculate that the onset of glaciations on both poles and the shift from short and small to long and extensive glacial intervals at $0.9 \mathrm{Ma}$ could represent events having a strong ecological impact, and could have caused the appearance of a disjunct bipolar distribution in some species. However, only the Prunopyle antarctica event seems to match the time interval $(1.2-0.9 \mathrm{Ma})$, at the time when Pleistocene glaciations changed from a 41 to a 100 ka cycle. The stratigraphic range of Prunopyle tetrapila clearly indicates how this species was most common in the northern hemisphere and in the tropics. Prunopyle antarctica evolved in the lowermost Lower Pleistocene and, according to the chronology used by Stanley (1981), this transition occurred slightly later in the Antarctic. This would indicate a transport from north to south, which is in agreement with the theory of bipolarity proposed by Bergh (1947).

An indication of the importance of glacial cycles for the establishment of a bipolar distribution in Protozoa also comes from molecular biology investigations on planktonic foraminifera. Darling et al. (2004) discussed the genetic variation in Neogloboquadrina pachyderma from the Atlantic Arctic and the Antarctic. They obtained, by molecular dating, an estimate of 1.8-1.5 Ma for the divergence of the northern hemisphere left-coiling Neogloboquadrina pachyderma SSU genotype from the southern hemisphere left-coiling Neogloboquadrina pachyderma SSU genotype. They further concluded that the northern and southern SSU genotypes are mutually exclusive and remained genetically and geographically isolated until today. The two populations, after their initial isolation, were unable to maintain a genetic exchange across the tropics and have therefore been geographically and genetically isolated until today. In the southern hemisphere there are four SSU genotypes, and their diversification seems to be linked to glacial/interglacial climate dynamics. The left-coiling Neogloboquadrina pachyderma type IV separated from the other SSU genotypes around 1.1-0.5 Ma (i.e. during the climate system transition to $100 \mathrm{ka}$ glacial cycles).

All of the above-mentioned species assumed to be bipolar are typical representatives of the recent radiolarian fauna. Petrushevskaya (1986) mentioned two nassellarian species, Enneaphormis rotula Haeckel, 1881 (Appendix 1, 24) and Cycladophora davisiana davisiana (Ehrenberg, 1862) (Appendix 1, 40) as possible species of relict genera of Palaeogene 
or Cretaceous origin. These species presently inhabit subsurface waters in the geographical area bordering the centre of their origin (see Appendix 1), and never occur at the surface in the tropical zone. There are, in fact, indications that a bipolar geographical distribution was also characteristic for some components of ancient radiolarian faunas too, and bipolarity in radiolarians would then not necessarily be a very recent development. Species having a bipolar distribution were rather numerous in the postMiocene deposits from the Norwegian-Greenland Seas and the South Atlantic Ocean (Lazarus 2002). Additionally, the Early Palaeogene associations of the New Zealand area (Hollis 2002) are very similar to the associations found on the Russian Platform and in west Siberia (Kozlova 1999; Afanasieva et al. 2005). Amon (2000, 2003) suggested a bipolar distribution for some members of the Late Cretaceous genus Prunobrachium, whereas Vishnevskaya $(1991,2001)$ pointed to a possible bipolar distribution for several of the Jurassic and Cretaceous species recovered from the boreal province in Russia. Other authors noted the similarity of Triassic associations between east Siberia and New Zealand (Aita \& Bragin 1999). All this body of evidence, and several other reports from different areas of the world, seem to indicate that bipolarity in radiolarians is a rather ancient phenomenon.

We do not know when the present bipolar radiolarian species established themselves, but it is probably a relatively recent feature. Although it is still uncertain whether they established themselves as such after the last glaciation or after the development of northern hemisphere glaciation. In the latter case, they have also survived earlier glaciations. Geological and palaeontological evidence does not support vicariance as a process to create bipolar distributions (Lindberg 1991), but it instead favours biotic interchange, both southward and northward, between the hemispheres. These events are probably related to a plurality of mechanisms (i.e. regional tectonic events and Pleistocene glaciations), rather than a single event. This is in good agreement with our radiolarian events that indicate that the separation of species took place both before and during the northern hemisphere glacial onset.

The following conclusions can be drawn on the bipolarity of radiolarian taxa:

- All of the species of Phaeodaria, Spumellaria and Nassellaria having a bipolar distribution belong to the recent fauna, except for Prunopyle? tetrapila (extinct in the Pliocene). No Phaeodaria have any analogues in the fossil record, whereas in Spumellaria and Nassellaria we have several examples.

- Of the 46 recent species discussed here, only one is restricted to the polar areas, 26 have bipolarity type 1 (disjuncted areal distribution), of which two are examples of bionomical bipolarity, and 19 species are of bipolarity type 2 (equatorial submergence).

- At present, we know of only two bipolar Nassellaria species that are presumably relicts of Palaeogene and Cretaceous radiolarian genera, although additional examples may be found in the Miocene.

- Some bipolar species developed their bipolar distribution in Late Miocene, a time interval that is not associated with any northern glaciation events.

- Some bipolar species became disjunct in the Early Pleistocene (onset of the $100 \mathrm{ka}$ glacial cycles) and seem to have evolved from species with a cosmopolitan distribution.

- As bipolarity within polycystine radiolarian species arose at different times, the causes were probably active over a long time interval, and separation by temperature changes in the Pleistocene is only one of the possible reasons.

- The origin of the bipolar distribution of some radiolarian species can be explained by their deep-water migration through the cold meridional currents.

- Within the euradiolarians there are three bipolar genera, and no families or higher taxa.

\section{Peculiarities of the bipolar distribution of Medusozoa}

As noted earlier, Stepanjants et al. (1996, 1997a) discussed the bipolar distribution of Cnidaria: Medusozoa (Hydrozoa, Siphonophora and Scyphozoa; Anthozoa not discussed) based on numerous publications by taxonomists and faunists who have been working with these groups of invertebrates (Chun 1897; Vanhöffen 1902, 1906; Maas 1906, 1909; Broch 1910; Stepanjants 1967, 1979, 1989; Antsulevitch 1987; Margulis 1989; Van der Spoel 1991; Svoboda et al. 1995; Stepanjants et al. 1997a, 2004; Sheiko \& Stepanjants 1997a,b; Jarms \& Mühlenhardt-Siegl 1998; Stepanjants \& Svoboda 2001; Svoboda \& Stepanjants 2001). General faunistic and biogeographical investigations were carried out by Derjugin (1915), Bergh (1947) and Ushakov (1958). However, it is clear from these publications that these authors did not clearly understand the concept of "bipolar distribution", and they presented different explanations of this concept. The identification of species that were previously 
assumed to be bipolar is no longer trustworthy. For example, the Hydrozoa species Campanularia verticillata (Linnaeus, 1758), mentioned by Derjugin (1915) and Bergh (1947) as a "classically bipolar" species, in reality has another areal distribution, and it now belongs to the family Campanulariidae and is named Rhizocaulus verticillatus (Linnaeus, 1758) (Stechow 1919; Cornelius 1982, 1995a; Stepanjants 1989). Its distribution may be classified as Arcticboreal, and is only restricted to the northern hemisphere. Rhizocaulus verticillatus does not exist at all in the southern hemisphere, where another pan-Antarctic species of the family Campanulinidae (Stechow 1919; Stepanjants 1979), Stegella grandis (Hickson et Gravely, 1907), occurs. The vertical hydrothecae distribution on the polysiphonic stem and branches is very similar to that on the colonies of Rhizocaulus verticillatus, which is the only character common to both species.

At present, the reliability and accuracy of species identification within Medusozoa has significantly improved. There are now a significant number of well-qualified articles on the systematics of Cnidaria based on material obtained from the surface to abyssal depths from different regions and zoogeographical provinces of the World Ocean, from the Arctic to the Antarctic. A species list of Medusozoa based on the material in the large collections of the Zoological Institute of the Russian Academy of Sciences is now available in our database, along with a list of publications that are relevant to our bipolarity discussion (Briggs 1928, 1938; Hyman 1929, 1930, 1931a,b; Fraser 1940, 1941, 1943a,b, 1944, 1946; Manton 1940; Kramp 1942, 1943a,b, 1961, 1963, 1965, 1968; Russel 1953, 1970; Hirai \& Kakimura 1957; Vervoort 1959, 1966, 1967, 1968, 1972, 1985, 1993a,b; Naumov 1960, 1961, 1971; Brinckman 1962, 1965; Blanko 1963, 1967, 1969, 1977, 1978, 1980, 1982, 1991; Yamada 1964; Hirai \& Yamada 1965; Brinckmann-Voss 1966, 1970, 1989; Stepanjants 1967, 1975, 1979, 1980, 1988, 1989, 1994, 1998, 1999, 2001; Calder 1970, 1971, 1972a,b, 1975, 1983, 1984, 1986a,b, 1988, 1991, 1993a,b, 1996, 1997; Uchida 1970; Alvarino 1971; Christiansen 1972; Edwards 1972, 1973, 1983; Robins 1972; Bouillon 1975, 1978a,b,c, 1984, 1985, 1995a,b; Cornelius 1975a,b, 1979, 1982, 1987, 1990, 1992, 1995a,b, 1998, 1999; Millard 1975, 1977, 1978, 1979; Hirohito 1977, 1984, 1988, 1995; Vervoort \& Vasseur 1977; Kubota 1978, 1987, 1989, 1991, 1992a,b, 1993, 1999; Svoboda 1979; Margulis \& Karlsen 1980, 1985; Chapligina 1980, 1992, 1993; Arai \& BrinckmannVoss 1980; Larson 1980, 1988, 1990; Boero 1981; Kubota \& Yamada 1982, 1992; Antsulevitch \& Stepanjants 1985; Watson 1985, 1992, 1998; Calder
\& Vervoort 1986, 1998; Antsulevitch 1987; Campbell 1987, 1989; Rees \& Vervoort 1987; Jarms 1988, 1990, 1991, 1994, 1997; Larson \& Fautin 1989; Margulis 1989; Stepanjants \& Lobanov 1989; Brinckmann-Voss et al. 1989; Gibbons \& Riland 1989; Stepanjants et al. 1990, 1996, 1997a,b, 1998, 1999a, b; Namikawa et al. 1990, 1992; Beshbeeshy 1991; Larson et al. 1991; Namikawa 1991; Ryland \& Gibbons 1991; Svoboda \& Cornelius 1991; Yamada \& Kubota 1991; Boero \& Hewitt 1992; Kubota \& Takashima 1992; Pages et al. 1992; Ramil \& Vervoort 1992; Antsulevitch \& Vervoort 1993; Boero \& Bouillon 1993a,b; Pugh \& Pages 1993; Pages \& Kurbjeweit 1994; Boero et al. 1995; Medel \& Vervoort 1995, 2000; Segonzac \& Vervoort 1995; Svoboda et al. 1995, 1997; Marques 1996; Migotto 1996; Peña Cantero et al. 1996, 1997a, b; Schuchert 1996, 1997, 2001a,b, 2004; Stepanjants \& Dianov 1997; Pages 1997; Brinckmann-Voss \& Arai 1998; Gravier-Bonnet 1998, 1999; Jarms \& MühlenhardtSiegl 1998; Mapstone 1998; Marques \& Migotto 1998; Medel \& Lopez-Gonzalez 1998; Migotto \& Calder 1998; Peña Cantero 1998; Ramil et al. 1998; Stübing \& Piepenburg 1998; Panteleeva 1999; Panteleeva et al. 1999; Bouillon \& Boero 2000; Marques \& Calder 2000; Marques et al. 2000; Ansin Agis et al. 2001; Hewitt \& Goddard 2001; Stepanjants \& Svoboda 2001; Svoboda \& Stepanjants 2001; Watson \& Vervoort 2001; Bouillon et al. 2002; among others).

In most cases, the reliability of species identification does not give rise to any doubt. The conclusions below are based on a database that includes more than 800 species of Hydrozoa, Siphonophora, Scyphozoa and Cubozoa (Siphonophora are treated here as an independent class). This database includes information concerning species found in nine areas of the North Pacific [Pacific shores of Alaska, Aleutian Islands, Commander Islands, eastern shores of Kamchatka, Bering Sea, Okhotsk Sea, North Kurile Islands, South Kurile Islands (separated by the Friza Strait, between Urup and Iturup Islands), the northern part of the Sea of Japan, to about $40^{\circ} \mathrm{N}$ ]; 12 regions in the Arctic Basin (eastern Greenland, western Greenland, Canadian Arctic archipelago and Labrador shore, northern shore of Norway, Barents Sea, White Sea, Kara Sea, Laptev Sea, East Siberian Sea, Chukchi Sea and Beaufort Sea); 21 areas of the Southern Ocean (Ross Sea, Bellingshausen Sea, Weddell Sea, Sodruzestva Sea, Mousson Sea, Riiser-Larsen Sea, Cosmonaut Sea, Davis Sea, Dumont D'Urville Sea, Graham Land, Macquaire Island, South Georgia Island, the west Antarctic Islands; the open parts of the Indian, Atlantic, and Pacific Oceans, Patagonian shelf, 
South Africa, South Australia with Tasmania, southern part of New Zealand with adjoining islands).

The Medusozoa taxa that have a northern and southern hemisphere distribution, and that can be considered as bipolar according to our definition, are listed in Appendix 2. Within Medusozoa there are not only bipolar species, but also genera and families, in contrast to Radiolaria, where so far we have only found bipolarity within three genera, and otherwise mostly at the species level. According to newly published data, and new material that only recently became available, the previous list of bipolar Medusozoa taxa (Stepanjants et al. 1996, 1997a) is herein revised and updated (Appendix 2). The number of bipolar species is reduced by one third (23 species instead of 38) and we conclude that 32 genera and five families are bipolar. If the list of bipolar Medusozoa taxa (Appendix 2) is analysed further, it is possible to reach another four important conclusions:

- There are almost no fossil records of Medusozoa (except hydrocorals and Conulata) and whether these fossil Medusozoa are really Cnidaria or not is still debated and is very problematic.

- The group Medusozoa is highly plastic with respect to environments, which explains the high number of bipolar species, genera, and even families.

- The Medusozoa are organisms that are either completely pelagic or bottom dwellers having pelagic stages.

- A considerable part of the representatives of Hydrozoa is epibiotic (i.e. attachment on living organisms), a life cycle that allows for easy transportation of these species.

We would like to stress here that our concept of bipolarity has a wider definition than previously. Without doubt, it must be taken into consideration that about half of the bipolar Medusozoa species (11) are pelagic organisms. The remarkable part is that eight species have no bottom polyp stage at all, or that this stage has not been recognized: Paragotoea bathybia Kramp, 1942; Rhabdoon reesi (Shirley et Leung, 1970) (=Yakovia polinae Margulis, 1989); Botrynema brucei Browne, 1908; Ptychogastria polaris Allman, 1878; Dimophyes arctica (Chun, 1897) (Figures 4 and 5); Muggiaea bargmannae Totton, 1954; Atolla wyvillei Haeckel, 1876; Periphylla periphylla (Peron et Lessueur, 1809). Of these pelagic species, four are restricted mainly to deep waters.

The bipolar distribution of these four species probably appears because of the presence of deepwater meridional polar and subpolar currents (Vino- gradov 1968). This does not contradict classical theories, and is also close to the interpretations of Ross (1847), Ortmann (1896) and Chun (1897), and to some modern opinions, such as Birstein (1963), Andriashev (1987) and others (see above). All the cases cited are preferably interpreted as a result of modern deep-water migrations. It is possible that Voragonema profundicola (pendunculata?) Naumov, 1971 will in the future be placed in the same group. In our opinion, this species is the only representative of the genus Voragonema. Nevertheless, three known species of this genus are reported in the literature, and the last one, Voragonema laciniata, was described from the Weddell Sea from a depth of $1583 \mathrm{~m}$ (Bouillon, 2002).

The other 13 bipolar species have polyp with epibiotic stages: Obelia longissima (Pallas, 1766); Staurophora mertensii Brandt, 1835; Filellum serpens (Hassal, 1848); Monobrachium parasitum Mereschkowsky, 1877; or are found as attachments: Sertularella polyzonias (Linnaeus, 1758); Sertularella gayi (Lamouroux, 1821); Symplectoscyphus tricuspidatus (Alder, 1856); Abietinaria abietina (Linnaeus, 1758); Grammaria abietina (Sars, 1851); Acryptolaria conferta (Allman, 1877); Kirchenpaueria pinnata (Linnaeus, 1758); Kirchenpaueria bonneviae (Billard, 1906); Halopteris catharina (Johnston, 1833). The distribution of these species is connected with fouling on ships, drifting algae and other swimming organisms. Their plasticity to the environment has given them the ability to adapt and tolerate rather uncomfortable conditions, for example the high temperatures in the tropics. They penetrate these water masses and adapt to new territories in the two hemispheres having adequate environments because stable populations of these species are absent in the tropics.

Let us now analyse in detail the bipolar distribution of some species. Within pelagic Medusozoa, the characters of the siphonophora Dimophyes arctica (Chun, 1897) are well known. This species was first found in the Arctic only, then, based on investigations from all zones of the World Ocean, it was also found in the Antarctic, as well as in the Caribbean Sea and other tropical regions (Stepanjants 1975). For a long time it was presumed to be a cosmopolite, whereas later it was shown that cold-water masses and currents limited its distribution. The use of statistical methods (Stepanjants \& Lobanov 1989), including a computer visualization method (Stepanjants \& Dianov 1997), allows us to show how this species spawns in waters of polar origin. It was found in the Caribbean Sea, at depths between 500 and $200 \mathrm{~m}$ and at temperatures below $10^{\circ} \mathrm{C}$ and salinity $<35$ psu. This indicates penetration of Subantarctic water masses to this region (Figure 5). 


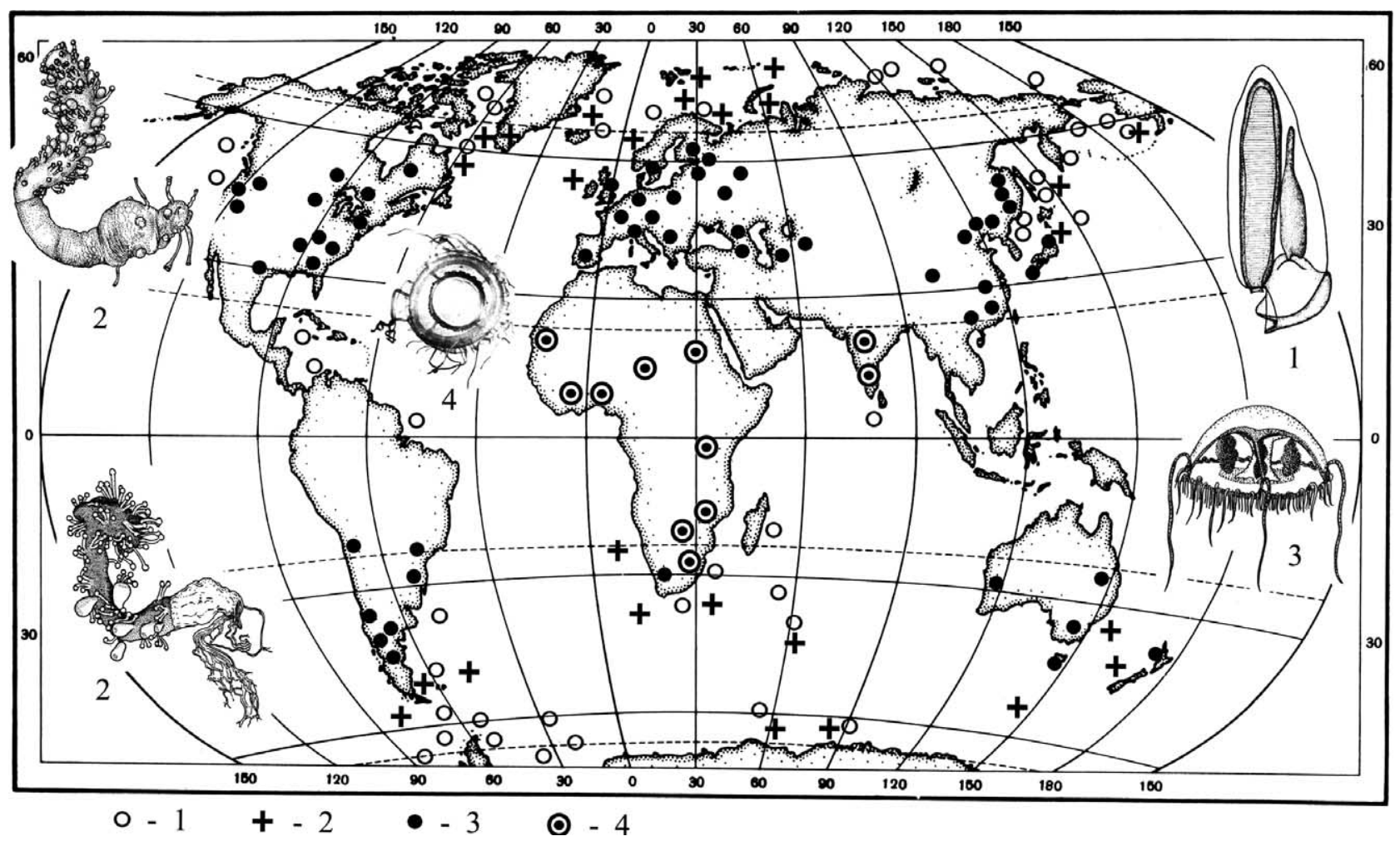

Figure 4. The bipolar distribution of some Medusozoa (Cnidaria) taxa. The numbers in parentheses refer to the species numbers in Appendix 2. 1, Dimophyes arctica (Chun, 1897) (no. 20); 2, family Candelabridae, represented by genus Monocoryne with M. giganthea (northern hemisphere, upper left) and M. minor (southern hemisphere, lower left); 3, Craspedacusta sp., showing a bipolar distribution; 4, Limnocnida sp., showing a tropical distribution only.

Some reports of Dimophyes arctica are also from the tropical zone, at depths of about $1000 \mathrm{~m}$. It is possible to interpret the Dimophyes arctica appearance in the tropics as a result of cold-water masses penetrating into the tropical zone. The distribution of the siphonophora Muggiaea bargmannae can be explained by the same mechanism as for Dimophyes arctica. The species Muggiaea bargmannae is practically always accompanied by Dimophyes arctica in the Arctic and in the North Pacific, and it is known that Muggiaea bargmannae inhabits waters with temperatures between -1.45 and $+4^{\circ} \mathrm{C}$ (Stepanjants 1967).

There is no pelagic stage in Filellum serpens (Hassal, 1848). This is an epibiotic organism, whose colonies cover other organisms, preferably other hydroid species, but without any preference to settle on specific hydroid species. Previously, most taxonomists and faunists assumed Filellum serpens to be cosmopolitan. Derjugin (1915) was the first who suggested this species to be bipolar, later supported by Stepanjants (1980). However, until now there has been no clear understanding of which characters are important in the distribution of Filellum serpens. It has been found in the Arctic and Antarctic, in cold and temperate waters of the Pacific and Atlantic Oceans, mainly at depths from 9-300 to $3500 \mathrm{~m}$.
The fact that this species was found near the western shore of tropical Africa excludes the possibility of an antitropical distribution. However, an ecological approach to the interpretation of bipolarity allows us, following Darwin and Bergh (see above), to classify this species distribution as bipolar. In other words, the penetration of Filellum serpens into the tropics must be connected to the cold-water masses along the west African shore.

Monobrachium parasitum Mereschkowsky, 1877 is epibiotic, living on the shells of various bivalves. New data by Jarms \& Mühlenhardt-Siegl (1998) show that this species is widely represented in the Arctic. It also settles substantially in the Antarctic and in areas around the Falkland Islands. It inhabits shells of four to five species of bivalves in the Arctic and North Atlantic, six species in the Antarctic and about 10 species in the North Pacific. In each of the mentioned areas, the bivalve species are different and the hydroid distribution is most probably independent from the substratum. According to Jarms \& Mühlenhardt-Siegl (1998), the bipolar distribution of Monobrachium parasitum is connected with its migration from the Southern Ocean during the Mesozoic, in accordance with Crame (1974, 1996) and Van der Spoel (1991). We, on the other hand, would conclude that there are clear differences 


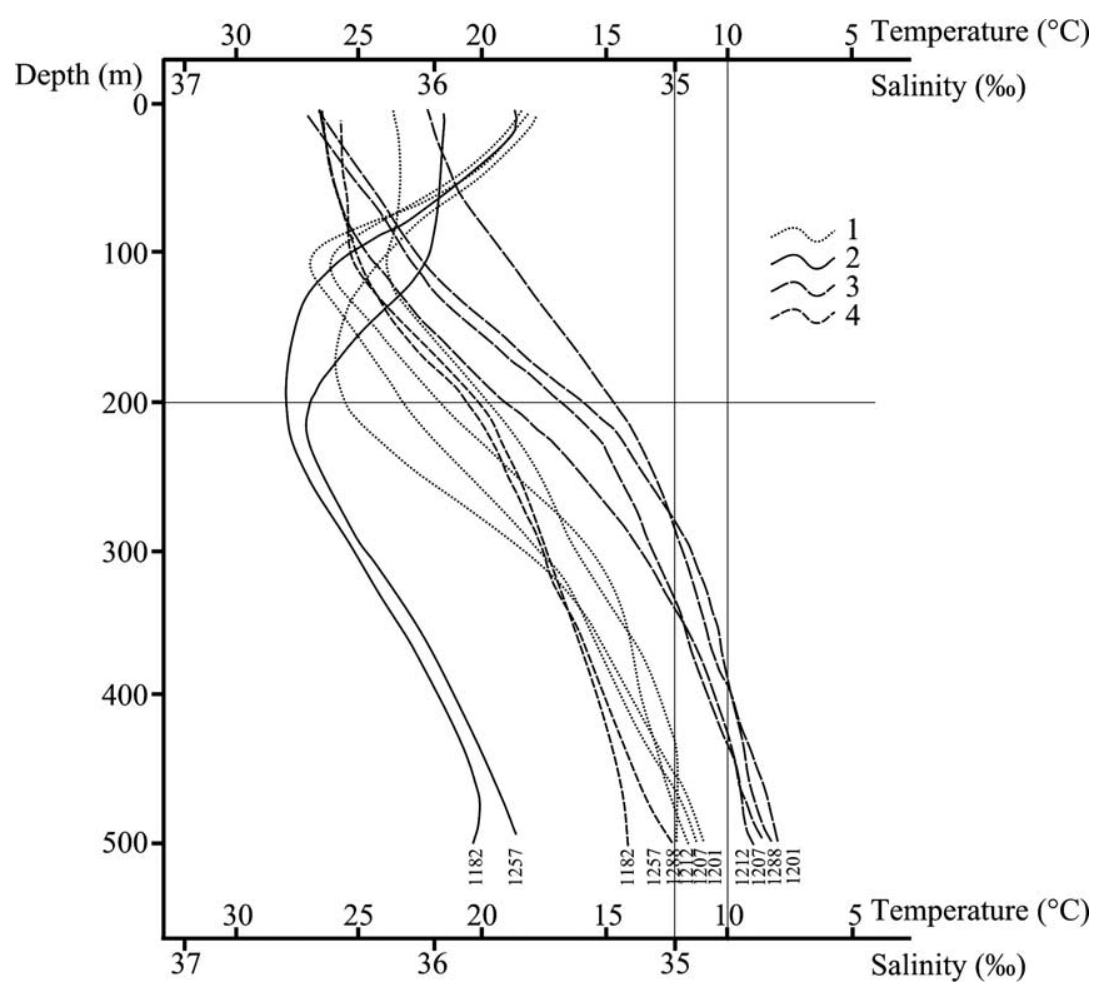

Figure 5. Temperature and salinity profiles at the Caribbean Sea stations with and without Dimophyes arctica (Chun, 1897), according to Stepanjants (1975). Station numbers are given below each curve. 1, Stations with $D$. arctica, salinity profile; 2 , stations without $D$. arctica, salinity profile; 3 , stations with $D$. arctica, temperature profile; 4 , stations without $D$. arctica, temperature profile.

in the northern and southern populations of Monobrachium parasitum in some characters (Jarms \& Mühlenhardt-Siegl 1998). This allows us to conclude that these two forms are different but closely related cold-water species. These two species are in turn closely related to the third Antarctic species of this genus, namely Monobrachium antarcticum (Robins, 1972). The morphological similarity between these three species can be explained as a result of inhabiting the same biotope, i.e. settling on bivalve shells.

The other 10 species (see above) are found in high numbers and have a wide distribution, usually in temperate, but also in cold waters of both hemispheres. Their general distribution patterns have two explanations: (1) recruitment is most probably from the north to the south through deep-water currents; (2) recruitment occurs via attachment on drifting substrata.

Finally, Craspedacusta sowerbyi (Lankester, 1880) is a typical inhabitant of freshwater basins. This species has a free-living medusae stage and its polyps are minute organisms without tentacles. In the northern hemisphere, this species is known from freshwater lakes in Europe, continental Asia, Japan and North America, whereas in the southern hemisphere it is reported from South America and Australia (Figure 4, Craspedacusta sp. is shown).
Representatives of the closely related genus Limnocnida (in the same family) inhabit the tropical zone of India and central Africa, as well as in South Africa, according to Bouillon (1956-1957) (Figure 4). At present, the genus Craspedacusta includes six species (Bouillon \& Boero 2000). These authors erroneously placed a seventh species, Craspedacusta vovasi, in it, which has now been re-named Eperetmus typus vovasi (Naumov \& Stepanjants 1971; Stepanjants 1988). The validity of the five other species is also doubtful, and they are only found in Asia. The origin of the bipolar distribution of Craspedacusta sowerbii is explicable by transport of algae attached to birds. This transport takes place from the Asian continent (Figure 4) westwards (Eurasia and Europe) and southwards (Australia and South America). The discovery of the limnomedusa Kirklandia in Germany and America in Jurassic-Cretaceous sediments supports the idea of an ancient origin for this group, as proposed by Harrington \& Moore (1956).

Among the 32 bipolar genera of Medusozoa, some deserve special attention. Two of these genera are monotypical: Paragotoea and Dimophyes. The third monotypical genus, Yakovia, is reported to be a synonym of Rhabdoon with two species (one from the northern hemisphere and the other from both the northern and southern hemispheres; Stepanjants 
and Kosobokova, in press). The species placed in Paragotoea is from the Arctic and from temperate waters of the southern hemisphere (Paragotoea bathybia Kramp, 1942). Later Margulis (1989), probably erroneously, described another species from the Arctic and Antarctic as Paragotoea elegans. We support the opinion of Brinckmann-Voss \& Arai (1998) and Bouillon \& Boero (2000) who designated $P$. elegans a junior synonym of Paragotoea bathybia. As mentioned earlier, the genus Voragonema is also monotypical, with the species Voragonema profundicola, and accordingly is also a bipolar genus. This means that only monotypic genera are known among pelagic Medusozoa having a bipolar distribution. As stated, the distribution of these genera and species takes place via the mechanism that is typical for deep-water pelagic forms, namely through cold-water meridional currents, as also stated by Vinogradov (1968).

Twelve bipolar genera of Medusozoa are represented by a rather large number of species (two to five or more). As a rule these species are closely related, but they are different in the northern and southern hemispheres and are absent from the tropical zone. They are epibionts, whereas other species are either distributed via the actinula-like larval stage or are pelagic. According to the present status of knowledge, this is the number of species for these genera: Gymnogonos - five; Monocaulus - four; Bouillonia - three; Monocoryne - five; Candelabrum - 15; Rosalinda - four; Monobrachium - three; Margellopsis - five; Staurophora - two; Ptychogastria - three; Voragonema - three; Craspedacusta - five(?). The species from the northern and southern hemispheres are very similar and it is often difficult to distinguish between them. Examples of such species are: Gymnogonos crassicornis Bonnevie, 1898 from the Arctic and Gymnogonos ameriensis (Stepanjants, 1979) from the Antarctic (Stepanjants \& Svoboda 2001); Monocaulus groenlandicus Allman, 1876 from the Arctic and Monocaulus parvula (Hickson \& Gravely, 1907) from the Antarctic (Svoboda \& Stepanjants 2001) (Figure 6).

The species Monocaulus groenlandica (Arctic) and Monocaulus parvula (Antarctic), in the family Corymorphidae, are not only morphologically and anatomically similar, but some fine structures in the polyps of both species have orange-brown colouring that is still preserved after more than 100 years of fixation. This coloration is ensured by pigment granules in cells of the epiderm and gastroderm, after applying the thyrosin-tryptophan group of the carbolic acid as a tissue dye. The coloration is a character typical for these species and distinguishes them from other Corymorphidae species (Svoboda \& Stepanjants 2001). The genus
Corymorpha contains 11 species that are distributed mainly in the tropical and subtropical zones of the World Ocean, which represent possible centres of origin for these family and genera. From these zones Corymorpha (Steenstrupia) nutans (Sars, 1835) penetrates to the north, and the monotypic genus Paragotoea (with Paragotoea bathybia) penetrates to the south. A neothenic origin of the cold-water Gymnogonos and Monocaulus is more probable. Although there are no fossils that are close to the present Corymorphidae representatives, it is nevertheless possible that this group is relict.

The species in the genus Candelabrum were recently revised in great detail (Segonzac \& Vervoort 1995; Hewitt \& Goddard 2001), and their coldwater nature is well documented. Most of the 15 known species inhabit the temperature interval 2.4$11^{\circ} \mathrm{C}$, and are restricted to significant depths. Stepanjants (1989) reported that Candelabrum phrygium (Fabricius, 1780) inhabits and reproduces in the northern hemisphere at temperatures between 1 and $7^{\circ} \mathrm{C}$. The other species of this genus are restricted to the southern hemisphere, where they inhabit mainly Subantarctic waters with temperatures between 0.5 and $5^{\circ} \mathrm{C}$. The closely related species of the genus Monocoryne (the other genus belonging to the family Candelabridae) are also cold-water inhabitants in the Arctic, in the boreal Atlantic and Pacific, and in the southern hemisphere near South Africa (Stepanjants et al. 2004). As a result there are basic data supporting our conclusion that the family Candelabridae is also bipolar (Figure 4). In spite of the absence of fossil data, we propose that the representatives of this family are relict. We suggest that their distribution, most probably from the northern to the southern hemisphere, took place during the last 65 million years, and at great depths, as also suggested by the fact that the present forms also have a tendency to inhabit considerable depths. The fact that the Candelabridae fauna of the southern hemisphere is noticeably richer than the one of the northern hemisphere (nine against six species for Candelabrum and three against two for Monocoryne, respectively), may indicate that a second centre of speciation appeared in the southern hemisphere. The presence of Candelabridae species at the Antarctic shelf, where temperatures are between 0.5 and $1.9^{\circ} \mathrm{C}$, displays similarities to their distribution in the northern hemisphere, where Candelabrum phrygium and Monocoryne gigantea also inhabit the shallow waters of the high Arctic.

Within the two other families closest to Candelabridae, such as Rosalindiidae and Fabulosiidae (it is considered that this is a valid family with Fabulosus as a type genus; see Stepanjants et al. 1990), it is known that Rosalindiidae display a tendency to 


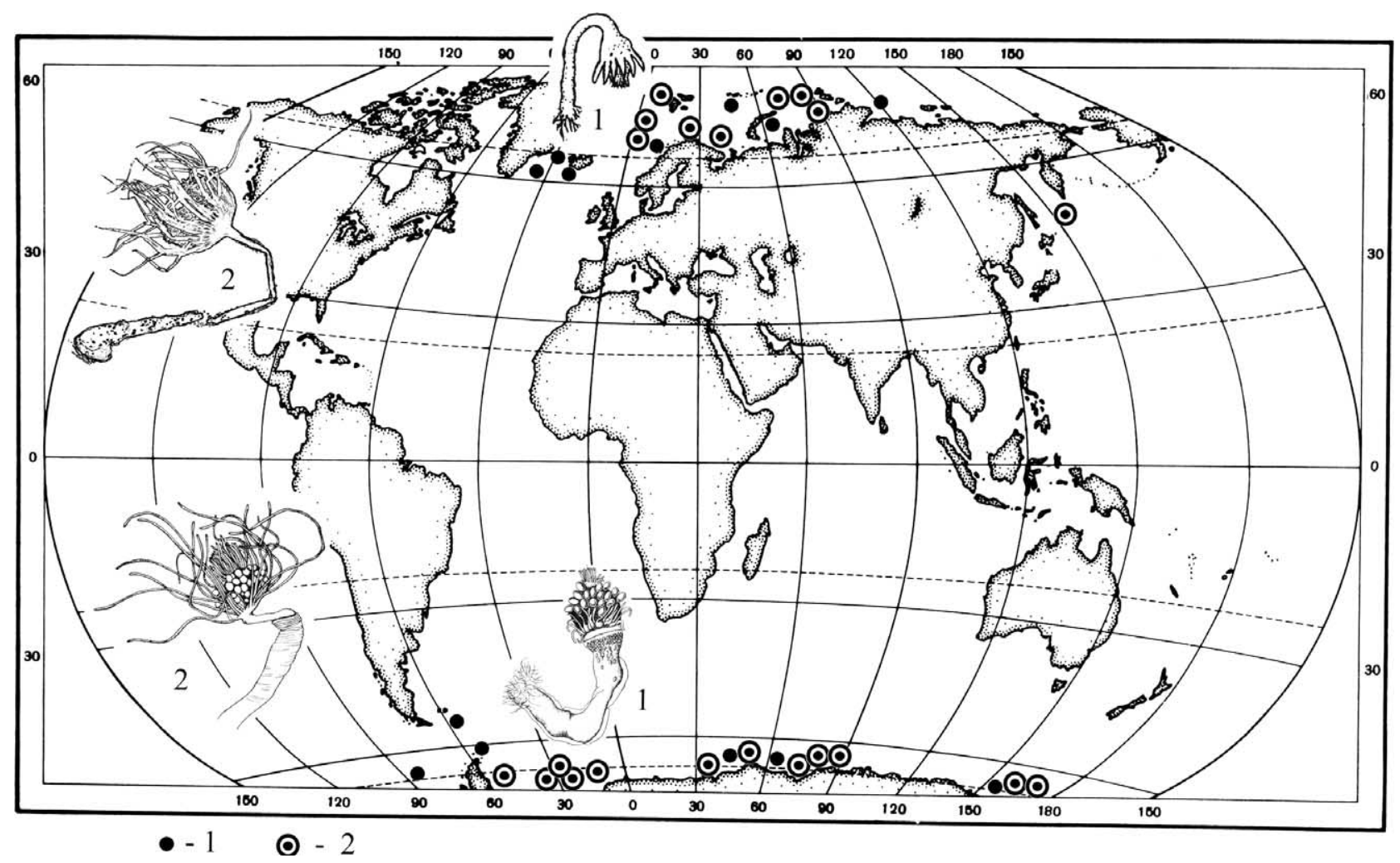

Figure 6. The bipolar distribution of the genera Gymnogonos and Monocaulus (Hydrozoa, Athecata, Corymorphidae) (Appendix 2). 1, Genus Gymnogonos here includes G. crassicornis Bonnevie, 1898 (1 upper centre) and G. obvolutus (Kramp, 1933) in the northern hemisphere and G. ameriensis (Stepanjants, 1979) (1 lower centre) in the southern hemisphere. 2, Genus Monocaulus here includes $M$. groenlandica Allman, 1876 (2 upper left) and M. parvula (Hickson \& Gravely, 1907) (2 lower left).

bipolarity (only the genus Rosalinda is bipolar, with four species), whereas the Fabulosiidae include only the northern Pacific species Fabulosus kurilensis Stepanjants, 1990. However, as the latter family is strongly related to the family Candelabridae, possibly having a bipolar distribution, it is not unlikely that Fabulosus kurilensis can also be found in the southern hemisphere.

Some genera include many species, such as Rhizogeton (six), Zygophylax (53), Ptychogena (seven), Staurotheca (20), Kirchenpaueria (six) and Schizotricha (10), of which many may be considered as bipolar. The genus Rhizogeton undoubtedly includes cold-water species, but the number of species included in this genus is yet not settled. For example, the species Rhizogeton nudum Broch, 1910 was described from the Arctic, but Millard (1975) also found it in cold waters on the shores of South Africa (Agulhas Bank). However, in our opinion the species identified by Millard (1975) as Rhizogeton nudum probably belongs to another coldwater species of the same genus.

We recognize here Zygophylacidae as the valid name of a family that includes three genera: Abietinella, Cryptolaria and Zygophylax. The species of the genus Abietinella are not found in the northern hemisphere, whereas the species of the genus Cryptolaria inhabit subtropical and tropical shallow waters. The last revision of the genus Zygophylax (Rees \& Vervoort 1987) led to about 53 species being included in this genus. These species inhabit the subtropical waters of the northern and southern hemispheres, usually deeper than $100 \mathrm{~m}$. Only one species is known from the Arctic, Zygophylax pinnata (Sars, 1874) and one from Subantarctic, Zygophylax armata (Ritchie, 1907). The fact that 12 species of the genus Zygophylax have been found in the tropical zone, but at depths between 200 and $1600 \mathrm{~m}$, clearly proves this genus to be bipolar, and indicates a deepwater origin of these species. Their migration possibly took place northwards and southwards via deep waters along North and South America, where an independent cold-water (polar shelf) fauna developed on both hemispheres. It is possible that these migrations took place before the onset of the northern hemisphere glaciation.

The family Kirchenpaueriidae evolved from the warm-water superfamily Plumularioidea (Plumulariidae, Aglaopheniidae, and Halopteridae). Genera and species of Halopteridae are represented in high numbers in the tropics and subtropics, whereas species of Kirchenpaueriidae belonging to the genera 
Kirchenpaueria, Oswaldella, Ophinella, Ventromma, Naumovia and Wimveria are usually typical for cold waters (Stepanjants et al. 1996, 1997a, 1998), as is also true for Schizotricha (Halopteridae). The genera Pycnotheca and Halicornopsis (family Kirchenpaueriidae) display some typical morphological characters exclusive to these colonies and are found in warm water on the shores around Australia and New Zealand. We suppose that the genera Pycnotheca and Halicornopsis must be investigated in greater detail in order to erect a new family for them. If this can be done, it will be possible to conclude that the family Kirchenpaueriidae is bipolar.

There are no bipolar species among the very large family Sertulariidae (more than 400 species). Among genera of this family, however, the genus Papillionella may be regarded as bipolar (Antsulevitch \&Vervoort 1993) (Appendix 2).

The genus Sertularia, with more than 20 species in the northern hemisphere (mainly with two rows of hydrothecae on the branches), and the genus Thuiaria, with more than 50 species (with many rows of hydrothecae on the branches, as a result of polymerization of the row numbers), are both absent in the Southern Ocean. The closely related genus Staurotheca includes 19 species (Peña Cantero et al. 1997b; with four to many rows of hydrothecae), and is distributed in the Southern Ocean. If we take into account that the hydrothecae distribution has a staurotheca form on the branches of some Sertularia and Thuiaria (in two rows that are perpendicular to each other), or that, on the contrary, some Staurotheca hydrothecae are distributed similarly on the branches as on the northern Sertularia and Thuiaria, we may be able to propose a close relationship between these genera. Similarly, we can discuss the Southern Ocean species group as having originated from the northern Sertularia genus (and possibly also from the Thuiaria genus), from which the Staurotheca genus in the south evolved.

Among the Medusozoa species investigated are undoubtedly some species whose distributions could be used as examples of ecological (bionomical) bipolarity, in spite of the fact that until now some species from both hemispheres were considered to be one taxonomical species, or two closely related species, belonging to the same genus. Another interesting case can be added to these examples: two obviously very different species of the family Hydractiniidae, Stylactaria (Hydractinia?) ingolfi Kramp, 1932 from the Arctic and Hydractinia vallini Jaederholm, 1926 from the Antarctic, are both attached as epibiotic organisms on different Ophiura species that belong to the family Ophyolepididae. This would represent a textbook example of ecological (bionomical) bipolarity. In spite of small differences, there are great morphological similarities between colonies and zooids of these species (Svoboda et al. 1995, 1997), which is also supported by very similar environments.

Ushakov (1958) compared faunas from shallow waters in the Subantarctic and North Pacific islands, and showed their bionomical similarity. Sheiko \& Stepanjants (1997a,b) studied peculiarities in the hydroid taxacoenoses of the Commander Islands, and demonstrated that the families Sertulariidae (45\%), Campanulariidae (20\%), Haleciidae $(10 \%)$ and Lafoeidae $(10 \%)$ were dominant. Our analysis of the taxocoenoses on the Subantarctic islands has produced very homogenous results, and the families Sertulariidae (20\%), Campanulariidae $(11.6 \%)$ and Haleciidae $(8.7 \%)$ are the most dominant, based on species number. This can be used as evidence of bionomic similarity of polar faunas.

It is possible to summarize our data on the bipolar distribution of Medusozoa as follows:

- All the 23 species of Medusozoa (Cnidaria) whose distribution may be defined as bipolar are contemporary. There are very few analogues of closely related species in the fossil record, represented by imprints or skeletal remains.

- Among 32 bipolar Medusozoa genera there are some, such as Gymnogonos, Candelabrum, Monocoryne and Rosalinda, which we assume to be relict, in spite of the absence of fossil remains.

- The origin of the bipolar distribution of the Medusozoa, mostly at the species and genus level, is a result of the high plasticity of this group, due to the modern migration via cold deep-water currents, either at the larval stage, or as a result of attachment on drifting organisms and objects.

- The distribution of relict forms during the Recent, together with the modern migrations, resulted in the formation of a sufficiently rich cold-water Medusozoa fauna, which is well represented today by bipolar taxa at the species, genus and even at the family level.

- Among the representatives of the cold-water Medusozoa fauna there are examples of welldefined ecological (bionomical) bipolarity at both the generic and coenotic levels, which developed in both polar regions.

\section{Conclusions}

1. In this paper, bipolarity is interpreted as the wide distribution of the same, closely related, or even not closely related taxa (at the species, 
genus or family level) of the flora and fauna, which are characterized by very similar characters and linked to similar environments in the cold and temperate zones and cold waters of both hemispheres.

2. The bipolarity phenomenon is herein investigated using examples from the exclusively pelagic classes Euradiolaria and Medusozoa (phylum Cnidaria), the latter having both pelagic and benthic stages. In both groups, the phenomenon of bipolarity is very clearly represented.

3. In Radiolaria, bipolarity becomes apparent mostly at the species level. Only three genera, as we suggest, are bipolar in their distribution. This is probably explained as a result of the fauna of Radiolaria-Polycystina being most diverse and abundant in the equatorial-tropical area. The Recent Arctic fauna only migrated into the Arctic Ocean in Holocene time, and some family and genera are absent or can be recognized only from the Pliocene-Pleistocene in typical faunas of cold-water areas of the World Ocean.

4. The Medusozoa display a rich and typical coldwater fauna. Bipolar distribution is recognized at the species, genus and even family levels.

5. In both of the investigated groups, bionomical bipolarity is well developed at high and low latitudes, both at the taxonomic as well as the coenotic level.

6. In spite of their presence in both groups, relict forms are not common in either of the faunas. The origin of a bipolar distribution is generally interpreted herein as a result of recent (Holocene) migrations (after the last glaciation, the Weichselian). Although this is true for most of the examined species, we also present several examples of Pliocene and Pleistocene taxa that developed a bipolar distribution that predates the last glaciation.

\section{Acknowledgements}

We are thankful to all investigators who collected and organized the radiolarian and cnidarian material, and worked fruitfully on its taxonomy. This has made it possible to undertake interpretations on the bipolarity problem. We are thankful to our colleagues Dr B. I. Sirenko and Dr A. F. Emeljanov (Zoological Institute RAS, St. Petersburg), Dr A. I. Kafanov (Marine Biology Institute, Vladivostok), Dr D. Boltovskoy (University of Buenos Aires), Dr Stanley Kling (Scripps Institution of Oceanography, La Jolla) and Dr Oliver R. Anderson (LamontDoherty Earth Observatory, Palisades) for reading the manuscript and for their critical advice on its first version. Mr B. F. Anokhin (ZIN RAS) helped in preparing the figures. We are grateful for the critical and stimulating remarks and suggestions from the reviewers.

The present investigation was supported by the Russian Foundation of the Fundamental Researches (grants N 97-65-685, N 01-05-64-478), the Norwegian Research Council for Science and the Humanities, and the Nansen Foundation (Norwegian Academy of Sciences) for radiolarians (Kruglikova); by the Federal Programme "World Ocean" of the subprogram "Antarctic Fauna", Project N16 "Antarctic Biota", and the Nansen Foundation (Norwegian Academy of Sciences) for the Medusozoa (Stepanjants); by the Deutsche Forschungsgemeinschaft as part of the DFG-Research Center "Ocean Margins" of the University of Bremen, no. RCOM0395 (Cortese); by the Norwegian Research Council for Science and the Humanities, and the Natural History Museum, University of Oslo (Bjørklund).

\section{References}

Abelmann A. 1992a. Radiolarian flux in Antarctic waters (Drake Passage, Powell Basin, Bransfield Strait). Polar Biology 12:357-72.

Abelmann A. 1992b. Radiolarian taxa from Southern Ocean sediment traps (Atlantic sector). Polar Biology 12:373-85.

Abelmann A, Gowing MM. 1997. Horizontal and vertical distribution pattern of living radiolarians along a transect from the Southern Ocean to the South Atlantic subtropical region. Deep-Sea Research 43:361-82.

Afanasieva MS, Amon EO, Agarkov YV, Boltovskoy DS. 2005. Radiolarians in the geological Record. Paleontological Journal 39(3 Suppl. S):135-392.

Aita Y, Bragin NY. 1999. Non-Tethyan Triassic Radiolaria from New Zealand and northeastern Siberia. Geodiversitas (InterRad VIII, Paris/Bierville. 8-13 September 21 1997):503-26.

Alvarino A. 1971. Siphonophores of the Pacific with a review of the World Distribution. Bulletin of the Scripps Institute of Oceanography. University of California 16:1-432.

Amon EO. 2000. Upper Cretaceous Radiolarians from the Ural Mountains. In: Materials of Stratigraphy and Paleontology of the Ural Mountains, vol. 5. Institute Geology and Geochemistry of the Ural Division of the Russian Academy of Sciences, Yekaterinburg, pp. 1-209.

Amon EO. 2003. Certain Patterns of the Global Geographical Distribution of the Late Cretaceous Radiolarians of the Genus Prunobrachium. Lithosphera, 4: 78-83. Institute Geology and Geochemistry of the Ural Division of the Russian Academy of Sciences, Yekaterinburg.

Andriashev AP. 1964. Review of the fish fauna of the Antarctic. Issledovanija Fauni Morey 2(10):335-86.

Andriashev AP. 1965. A general review of the Antarctic fish fauna. In: Van Mieghem J, Van Ove P, editors. Biogeography and Ecology in Antarctica. Hague: Junk. p 491-550.

Andriashev AP. 1967. About microflora and fauna connected with the Antarctic pack ice. Zoology Journal 46:1585-93.

Andriashev AP. 1970. Cryopelagic fishes of the Arctic and Antarctic and their significance in polar ecosystems. Antarctic Ecology 1:297-304. 
Andriashev AP. 1978. About the first fishes from the Antarctic, founded by captain J. K. Ross Expedition and about some questions of the marine cryobiology. Zoology Journal 67: 228-39.

Andriashev AP. 1986. The general review of the bottom fish fauna from Antarctic. Trudy Zoologicheskogo Instituta Akademii Nauk. SSSR 153:9-45.

Andriashev AP. 1987. Developing of the L. S. Berg's ideas about bipolarity of the marine fauna. Biologia Morya 2:60-7.

Andriashev AP. 1993. About validity of genus Psednos Barnard (Scorpaeniformes, Liparidae) and its antitropical area distribution. Voprosi ichtiologii 33:5-15.

Andriashev AP, Muchomediarov FB, Pavsteks EA. 1980. About the mass concentration of cryopelagic codfishes (Boreogadus salda and Arctogadus glacialis) at the nearpoles regions of the Arctic. Moscow: Nauka. p 196-211.

Ansin Agis J, Ramil F, Vervoort W. 2001. Atlantic Leptolida (Hydrozoa, Cnidaria) of the families Aglaopheniidae, Halopterididae, Kirchenpaueriidae and Plumulariidae collected during the CANCAP and Mauritania-II expeditions of the National Museum of Natural History, Leiden, the Netherlands. Zoologische Verhandelingen, Leiden. 333:1-268.

Antarctic Atlas 1966. General Administration of the Geodesy and the Cartography of USSR, Moscow, Leningrad, I-XXIII, Maps 1-225.

Antsulevitch AE. 1987. Hydroids of the shelf of the Kuril Islands. Leningrad: Zoologishe Institute of Academy, Nauk SSSR. p $1-166$

Antsulevitch AE, Stepanjants SD. 1985. The new representative of the rare genus Rosalinda (Hydroidea) at Far East waters. Zoology Journal 64:1140-7.

Antsulevitch AE, Vervoort W. 1993. Some little-known species of hydroids (Cnidaria: Hydrozoa: Lafoeidae) and description of Papilionella pterophora gen. nov., spec. nov. (Sertulariidae). Zoologische Mededlingen, Leiden 67:431-43.

Arai M, Brinckmann-Voss A. 1980. Hydromedusae of British Columbia and Puget Sound. Canadian Bulletin of Fisheries and Aquatic Sciences 204:1-192.

Averintsev VG. 1972. The bottom polychaetae Errantia of the Antarctic and the Subantarctic on materials of the Soviet Antarctic Expedition. Issledovanija Fauni Morey 11(19): 88-293.

Bailey JW. 1856. Notice of microscopic forms found in the sounding of the Sea of Kamtschatka. American Journ. Sci. Arts 22(64):1-6.

Barnard JL. 1959. Epipelagic and under-ice amphipoda of the Central Arctic Basin. In: C.R.C. Geophys. Res. Dir. U.S. Air Force, editor. Scientific Studies at Fletcher's Ice Island, T-3, 1952-1955. Bedford, MA. p 115-52.

Beers JR, Steward GL. 1971. Micro-zooplankters in the plankton communities of the eastern tropical Pacific. Deep-Sea Research 18:861-83.

Beklemishev KV. 1969. Ecology and Biogeography of the Pelagial. Moscow: Nauka.

Beljaev GM. 1989. Deepwater Oceanic Troughs and their Fauna. Moscow: Nauka.

Benson RN. 1966. Recent Radiolaria from the Gulf of California. $\mathrm{PhD}$ thesis, University of Minnesota.

Benson RN. 1983. Quaternary Radiolarians from the mouth of the Gulf of California, Leg 65 of the Deep Sea Drilling Project. In: Lewis BTR, et al., editors. Initial Reports of the Deep Sea Drilling Project. US Government Printing Office. p 491523.

Berggren WA. 1972. A Cenozoic time scale: some implications for geology and paleo-geography. Lethaia 5:195-215.

Bergh LS. 1920. Bipolar distribution of the organisms and a glacial epoch. Izvestija Akademii Nauk SSSR 14:273-302.
Bergh LS. 1933. Die Bipolare Verbreitung der Organismen und die Eiszeit. Zoogeographica 1:449-84.

Bergh LS. 1936. Theoretical considerations on biogeography. In: Bergh LS, editor. Ch. Darwin as Zoologist. Ch. Darwin. Selections Biol. and Med. Literature, Izdatel'stvo Biologisheskoy I Medicinskoy Literaturi, Moscow, Leningrad. p 32-6.

Bergh LS. 1947. Bipolar distribution of the organisms and a glacial epoch. In: Bergh LS, editor. Climate and Life. The Second Issue. Moscow: Geographgys. p 128-55.

Bergh LS. 1977. Statutes of the formation of organic forms. III. Statutes of the geographic order. 1. Transformed role of the landscape. 2. Selected role of the landscape. In: Bergh LS, editor. Transactions on the Theory of Evolution. Nomogenesis or Evolution on the Base of the Conformity. Leningrad: Nauka. p 95-336.

Bernstein T. 1934. Zooplankton des Nordlischen teiles des Karischen Meeres. Transactions of the Arctic Institute IX. p 3-58.

Beshbeeshy ML. 1991. Systematische, morphologische und zoogeographische Untersuchungen an den Thecaten Hydroiden des Patagonischen Schelfs. Universität Hamburg.

Birstein YA. 1960. Family Ischnomesidae (Crustaceae, Isopoda, Asellota) at the North-West Pacific and problems of the amphiboreal and bipolar distribution of the deep-water fauna. Zoology Journal 39:3-28.

Birstein YA. 1963. Deep-water isopodae (Crustacea, Isopoda) of the North-West Pacific. M. Izdatel'stvo Academii Nauk SSSR, Moscow, Leningrad.

Bjørklund KR. 1973. Radiolarians from the surface sediment in Lindåspollene, western Norway. Sarsia 53:71-5.

Bjørklund KR. 1974. The seasonal occurrence and depth zonation of radiolarians in Korsfjorden, Western Norway. Sarsia $56: 13-42$.

Bjørklund KR. 1976. Actinomma haysi, n. sp., its Holocene distribution and size variation in Atlantic Ocean sediments. Micropaleontology 23:114-26.

Bjørklund KR. 1984. Euphysetta (Phaeodaria, Radiolaria) in the Norwegian-Greenland Sea sediments (distribution in space and time). In: Petrushevskaya MG, Stepanjants SD, editors. Morphology, Ecology and Evolution of Radiolarians. Leningrad: Nauka. p 239-44.

Bjørklund KR, Ciesielski PF. 1994. Ecology, morphology, stratigraphy, and the paleoceanographic significance of Cycladophora davisiana davisiana. Part I: Ecology and morphology. Marine Micropaleontology 24:71-88.

Bjørklund KR, Cortese G, Swanberg NR, Schrader HJ. 1998. Radiolarian faunal provinces in surface sediments of the Greenland, Iceland and Norwegian (GIN) Seas. Marine Micropaleontology 35:105-40.

Bjørklund KR, Goll RM. 1984. Final stages of skeletal formation and early stages of disintegration for modern polycystine Radiolaria. EURORAD News Radiolaria 9:78.

Bjørklund KR, Kruglikova SB. 1998. Structure of radiolarian assemblages on high rank taxa and species level from the Recent sediments of the Greenland-Iceland-Norwegians Basin and Norwegian fjords. Elsevier, Abstracts of 6th L. P. Zonenshein Memoir Conference on Plate Tectonics: 153.

Bjørklund KR, Kruglikova SB. 2003. Polycystine radiolarians in surface sediments in the Arctic Ocean basins and marginal seas. Marine Micropaleontology 49:231-73.

Blanko OM. 1963. Sobre algunos sertularidos de la Argentina. Notas del Museo de la Plata 20 Zool. 203:163-80.

Blanko OM. 1967. Contribucion al conocimiento de los hidrozoarios Argentinos. Revista del Museo de la Plata nov.ser. 9 Zool. 71:243-97.

Blanko OM. 1969. Un nuevo Sertularido antartico Symplectoscyphus naumovi nov. sp. Neotropica 15(46):14-6. 
Blanko OM. 1977. Nuevos hidrozoos Antarticos. Contribucion del Instituto Antartico Argentino 205:1-15.

Blanko OM. 1978. Adicion a los hidrozoos Antarticos Argentinos. Neotropica 24(72):73-5.

Blanko OM. 1980. Acercade los especies del genero Symplectoscyphus Stechow, 1924 (Hydrozoa Sertulariidae). Neotropica 26(76):197-203.

Blanko OM. 1982. Adicion a los hidrozoos Argentinos, I. Neotropica 28(80):153-63.

Blanko OM. 1991. Adicion a los hidrozoos Argentinos, III. Neotropica 37(97):11-4.

Blueford J. 1983. Distribution of Quaternary radiolarians in the Navarin Basin geologic province, Bering Sea. Deep-Sea Research 30:763-81.

Boero F. 1981. Systematics and ecology of the hydroid population of two Posidonia oceanica meadows. Pubblicazioni della Stazione Zoologica di Napoli (Marine Ecology) 2(3):181-97.

Boero F, Bouillon J. 1993a. Zoogeography and life cycle patterns of Mediterranean Hydromedusae (Cnidaria). Biological Journal of the Linnean Society 48:239-66.

Boero F, Bouillon J. 1993b. Fraseroscyphus sinuosus n.gen. (Cnidaria, Hydrozoa, Leptomedusae, Sertulariidae), an epiphytic hydroid with a specialised clinging organ. Canadian Journal of Zoology 71:1061-4.

Boero F, Bouillon J, Gravier-Bonnet N. 1995. The life cycle of Pteroclava krepfi (Cnidaria, Hydrozoa, Cladocorynidae), with notes on Asyncoryne philippina (Asyncorynidae). Scientia Marina 59:65-76.

Boero F, Hewitt C. 1992. A hydrozoan, Zanclella bryozoophila n.g., n.sp. (Zancleidae) symbiotic with a bryozoan, with a discussion of the Zancleoidea. Canadian Journal of Zoology 70:1645-51.

Bogorov VG. 1946. Zooplankton po sporam expeditsii na L/P “G. Sedov" 1937-1939 gg. [Zooplankton collected by the Sedov Expedition 1937-1939]. In: Buynitskiy VK, editor. Trudy Dreyfuyushchey expeditsii Glavsevmorputi naledokol nom parokhode "G. Sedov" 1937-1939". Moscow: Izd. Glavsevmorputi. p 336-70.

Boltovskoy D. 1987. Sedimentary record of radiolarian biogeography in the equatorial to Antarctic western Pacific Ocean. Micropaleontology 33:267-81.

Boltovskoy D. 1994. The sedimentary record of pelagic biogeography. Progress in Oceanography 34:135-60.

Boltovskoy D. 1998. Classification and distribution of South Atlantic Recent polycystine Radiolaria. Palaeontologia Electronica 1(2):116.

Boltovskoy D, Alder AV, Abelmann A. 1993. Annual flux of radiolaria and other shelled plankters in the eastern equatorial Atlantic at $853 \mathrm{~m}$ seasonal variations and polycystine speciesspecific responses. Deep-Sea Research 40:1863-95.

Boltovskoy D, Uliana E, Wefer G. 1996a. Seasonal variation in the flux of microplankton and radiolarian assemblage compositions in the northeastern tropical Atlantic at $2195 \mathrm{~m}$. Limnology and Oceanography 41:615-35.

Boltovskoy E, Boltovskoy D, Correa N, Brandini F. 1996b. Planktic foraminifera from the southwestern Atlantic $\left(30^{\circ}-\right.$ $60^{\circ} \mathrm{S}$ ): species-specific patterns in the upper $50 \mathrm{~m}$. Marine Micropaleontology 28:53-72.

Borgert A. 1901. Die nordischen Tripyleenarten. Nordisches Plankton 15:1-52.

Bouillon J. 1956. 1956-1957. Etude monographique du genre Limnocnida (Limnomeduse). Annales de la Societé Royale Zoologique de Belgique 2(87):1-500.

Bouillon J. 1975. Sur la reproduction et l'ecologie de Paracoryne huvei Picard. Archives of Biology 86:45-96.

Bouillon J. 1978a. Hydromeduses de l'archipel des Seichelles et du Mozambique. Revue de Zoologie Africaine 92:118-72.
Bouillon J. 1978b. Hydromeduses de la Mer de Bismarck (Papouasie, Nouvelle-Guinée). I. Anthoméduses Capitata (Hydrozoa-Cnidaria). Cahiers de Biologie Marine 19:249-97.

Bouillon J. 1978c. Hydromeduses de la Mer de Bismarck (Papouasie, Nouvelle-Guinée). II. Limnomedusa, Narcomedusa, Trachymedusa et Laingiomedusa (sous-classe nov.). Cahiers de Biologie Marine 19:473-83.

Bouillon J. 1984. Hydromeduses de la Mer de Bismarck (Papouasie, Nouvelle- Guinée). Partie IV. Leptomedusae (Hydrozoa, Cnidaria). Indo-Malayan Zoology 1:25-112.

Bouillon J. 1985. Essai de classification des HydropolypesHydromeduses (Hydrozoa- Cnidaria). Indo-Malayan Zoology $2: 29-243$.

Bouillon J. 1995a. Classe des Hydrozoaires. In: Grassé PP, Doumenc D, editors. Traité de Zoologie. Paris: Masson.

Bouillon J. 1995b. Hydromedusae of the New Zealand Oceanographic Institute. New Zealand Journal of Zoology 22:223-38.

Bouillon J, Boero F. 2000. Phylogeny and classification of Hydroidomedusae. The Hydrozoa: a new classification in the light of old knowledge. Thalassia Salentia. p 24.

Bouillon J, Pages F, Gili J-M. 2002. New species of benthopelagic hydromedusae from the Weddell Sea. In: Arntz WE, Clarke A, editors. Ecological Studies in the Antarctic Sea Ice Zone. Berlin: Springer. p 10-6.

Brandt K. 1895. Biologische und faunistische Untersuchungen an Radiolarien und anderen pelagischen Thieren. Zoologische Jahrbucher 9:27-74.

Briggs EA. 1928. Studies on Australian Athecate Hydroids, N1. Two new species of genus Myriothela. Records of the Australian Museum Sydney 16:305-15.

Briggs EA. 1938. Hydroida. Scientific Report Australians Antarctic Expedition 1911-1914 Series C(9):5-45.

Briggs JC. 1987. Antitropical distribution and evolution in the Indo-West Pacific Ocean. Systematic Zoology 36(3):237-47.

Brinckmann A. 1962. The life cycle of Merga galleri sp.n. (Anthomedusae, Pandeidae). Pubblicazioni della Stazione Zoologica di Napoli 33(1):1-9.

Brinckmann A. 1965. The biology and development of Rhysia automnalis gen. nov., sp. nov. (Anthomedusae-Athecatae, Rhysiidae fam.nov.). Canadian Journal of Zoology 43:941-52.

Brinckmann-Voss A. 1966. The morphology and development of Acaulis ilonae sp.n. (order Anthomedusae/Athecatae, Fam. Acaulidae). Canadian Journal of Zoology 44:291-301.

Brinckmann-Voss A. 1970. Anthomedusae/Athecata (Hydrozoa, Cnidaria) of the Mediterranean. Part.I. Capitata. Fauna e flora del Golfo di Napoli. p 39.

Brinckmann-Voss A. 1989. Sarsia cliffordi n.sp. (Cnidaria, Hydrozoa, Anthomedusae) from British Columbia, with distribution records and evaluation of related species. Canadian Journal of Zoology 67:685-691.

Brinckmann-Voss A, Arai M. 1998. Further notes on Leptolida (Hydrozoa: Cnidaria) from Canadian Pacific Waters. Zoologische Verhandelingen, Leiden. 323:37-68.

Brinckmann-Voss A, Lickey DM, Mills CE. 1989. Rysia fletcheri (Cnidaria, Hydrozoa, Rhysiidae), a new species of colonial hydroid from Vancouver Island (British Columbia, Canada) and the San Juan Archipelago (Washington, U.S.A.). Canadian Journal of Zoology 71:401-6.

Brinton E. 1962. The distribution of Pacific euphausiids. Bulletin of the Scripps Institute of Oceanography. University of California 8(2):51-269.

Broch H. 1910. Die Hydroiden der arktischen Meere. Fauna Arctica 5(1):129-248.

Brundin L. 1975. Circum-Antarctic distribution patterns and continental drift. Memoirs du Museum National d'Histoire Naturelle, Paris. A 88:19-27. 
Cachon J, Cachon M, Estep KW. 1990. Phylum Actinopoda Classes Polycystina [ $=$ Radiolaria] and Phaeodaria. In: Margulis L, Corliss JO, Melkonian M, Chapman DJ, editors. Handbook of Protoctista. Boston: Jones and Bartlett. p 334-46.

Calder DR. 1970. Thecate hydroids from the shelf waters of northern Canada. Journal of the Fisheries Research Board of Canada 27:1501-47.

Calder DR. 1971. Hydroids and Hydromedusae of southern Chesapeake Bay. Virginia Institute of Marine Science Special Paper. Marine Science 1:1-125.

Calder DR. 1972a. Some Athecate hydroids from the shelf waters of northern Canada. Journal of the Fisheries Research Board of Canada 29:217-28.

Calder DR. 1972b. Cnidaria of the Chesapeake Bay. Chesapeake Science 13:100-2.

Calder DR. 1975. Biotic census of Cape Cod Bay: hydroids. Biological Bulletin 149:287-315.

Calder DR. 1983. Hydroida from estuaries of South Carolina, USA: Families Sertulariidae and Plumulariidae. Proceedings of the Biological Society of Washington 96:7-28.

Calder DR. 1984. New observations on Cladocarpus flexuosus Nutting, 1900 (Hydrozoa: Plumulariidae), a bathyal hydroid from the Gulf of Mexico. Proceedings of the Biological Society of Washington 97:408-12.

Calder DR. 1986a. Symmetroscyphus, a new genus of thecate hydroid (family Thyroscyphidae) from Bermuda. Proceedings of the Biological Society of Washington 99:380-3.

Calder DR. 1986b. Class Hydrozoa. In: Sterrer W, editor. Marine Fauna and Flora of Bermuda. New York: Wiley Interscience. $p$ 127-55.

Calder DR. 1988. Shallow-water hydroids of Bermuda. The Athecate. Royal Ontario Museum, Life Sciences Contributions 148:1-107.

Calder DR. 1991. Shallow-water hydroids of Bermuda. The Thecatae, Exclusive of Plumualioidea. Royal Ontario Museum, Life Sciences Contributions 154:1-140.

Calder DR. 1993a. Bougainvillia aberrans (Cnidaria, Hydrozoa), a new species of hydroid and medusa from the upper bathyal zone off Bermuda. Canadian Journal of Zoology 71:997-1002.

Calder DR. 1993b. Local distribution and biogeography of the hydroids (Cnidaria) of Bermuda. Caribbean Journal of Science 29:67-74.

Calder DR. 1996. Hydroids (Cnidaria: Hydrozoa) recorded from depths exceeding $3000 \mathrm{~m}$ in the abyssal western North Atlantic. Canadian Journal of Zoology 74(9):1721-6.

Calder DR. 1997. Shallow-water hydroids of Bermuda (Superfamily Plumularioidea). Life Sci. Contr. R. Ontario Mus. $161: 1-85$.

Calder DR, Vervoort W. 1986. Plicatotheca anitae, a new genus and species of thecate hydroid from Bermuda and South Africa. Canadian Journal of Zoology 64:2021-3.

Calder DR, Vervoort W. 1998. Some hydroids (Cnidaria: Hydrozoa) from the Mid-Atlantic Ridge, in the North Atlantic Ocean. Zoologische Verhandelingen, Leiden 319:1-65.

Campbell R. 1987. A new species of Hydra (Cnidaria: Hydrozoa) from North America with comments on species clusters within the genus. Zoological Journal of the Linnean Society 91: 253-63.

Campbell R. 1989. Taxonomy of the European Hydra (Cnidaria: Hydrozoa): a reexamination of its history with emphasis on the species $H$. vulgaris Pallas, $H$. attenuata Pallas and $H$. circumcincta Schulze. Zoological Journal of the Linnean Society 95:219-44.

Candolle A.d. 1855. Gèographie botanique raisonnée; ou, Exposition des faits principaux et des lois concernant la distribution gèographique des plantes de 1 epoque actuelle, Volumes 1 2. Paris: Masson.
Casey RE, Partridge TM, Sloan JR. 1971. Radiolarian life spans, mortality rates, and seasonality, gained from recent sediment and plankton samples. Proceedings of the II Planktonic Conference, Rome 1970, Edizioni Tecnoscienza, 159-65.

Chapligina SF. 1980. Hydroids of the Foulings of the North-west Part of the Sea of Japan. Ecology of the Foulings of the Northwest Part of the Pacific Ocean. Vladivostok: DVNC AN SSSR. p 56-71.

Chapligina SF. 1992. About introduction of two species of Hydrozoa, Laomedea flexuosa and L. calceolifera (Cnidaria, Hydrozoa, Campanulariidae), in the Sea of Japan. Zoology Journal 71(9):5-10.

Chapligina SF. 1993. Hydroids of the fouling of the maricultura plants in Petr Veliky Bay of the Sea of Japan. Biologia Morya 2:29-36.

Chen PH. 1975. Antarctic Radiolaria. Deep Sea Drilling Project. Initial Report of the Deep Sea Drilling Project 28:437-513.

Christiansen BO. 1972. The hydroid fauna of the Oslo Fjord in Norway. Norwegian Journal of Zoology 20:279-310.

Chun C. 1897. Die Beziehungen zwischen dem arktischen und antarktischen Plankton. Stuttgart: Nügele.

Cleve PT. 1899. Plankton collected by the Swedish Expedition to Spitzbergen in 1898. Kungliga Svenska Vetenskaps-Akademiens Handlingar 32(3):25-51.

Cleve PT. 1900. The seasonal distribution of Atlantic plankton organisms. Göteborgs Kungliga Vetenskaps-Och VitterhetsSamhälles Handlingar. Ser.4 3:1-369.

Cleve PT. 1901. Plankton from the Indian Ocean and the Malay Archipelago. Kungliga Svenska Vetenskaps-Akademiens Handlingar 35(5):10-23.

Project Members. CLIMAP. 1976. The surface of the ice-age Earth. Science 191:1131-7.

Cornelius PFS. 1975a. The hydroid species of Obelia (Coelenterata, Hydrozoa: Campanulariidae), with notes on the Medusa stage. Bulletin of the British Museum (Natural History). Zoology 28:251-93.

Cornelius PFS. 1975b. A revision of the species of Lafoeidae and Haleciidae (Coelenterata: Hydroida) recorded from Britain and nearby seas. Bulletin of the British Museum (Natural History). Zoology 28:373-426.

Cornelius PFS. 1979. A revision of the species of Sertulariidae (Coelenterata, Hydroida) recorded from Britain and nearby seas. Bulletin of the British Museum (Natural History). Zoology 34:243-321.

Cornelius PFS. 1982. Hydroids and medusae of the family Campanulariidae recorded from the eastern North Atlantic, with a world synopsis of genera. Bulletin of the British Museum (Natural History). Zoology 42:37-148.

Cornelius PFS. 1987. Taxonomic characters from the hydranths of thecate hydroids. In: Bouillon J, Boero F, Cicogna F, Cornelius PFS, editors. Modern Trends in the Systematics, Ecology and Evolution of Hydroids and Hydromedusae. Oxford: Clarendon Press. p 29-42.

Cornelius PFS. 1990. European Obelia (Cnidaria, Hydroida): systematics and identification. Journal of Natural History 24:535-78.

Cornelius PFS. 1992. The Azores hydroid fauna and its origin, with discussion of rafting and medusa suppression. Arquipélago Life Earth Science 10:75-99.

Cornelius PFS. 1995a. North-west European thecate hydroids and their medusae. P.1. Laodiceidae to Haleciidae. In: Barnes RSK, Crothers JH, editors. Synopses of the British Fauna. New Series. London. p 1-347.

Cornelius PFS. 1995b. North-west European thecate hydroids and their medusae. P.2. Sertulariidae to Campanulariidae. In: Barnes RSK, Crothers JH, editors. Synopses of the British Fauna. New Series. London. p 1-386. 
Cornelius PFS. 1998. Taxonomic characters from the hydranths of live thecate hydroids: European Haleciidae (Cnidaria: Leptothecatae). Zoologische Verhandelingen, Leiden 323:7997.

Cornelius PFS. 1999. A changing taxonomic paradigm: studies on Obelia and some other Campanulariidae (Cnidaria: Hydrozoa). Zoosystematica Rossica. Suppl. N 1:5-16.

Cortese G, Bjørklund KR. 1996. The morphometric variation of Actinomma boreale (Radiolaria) in Atlantic boreal waters. Marine Micropaleontology 29:271-82.

Cortese G, Bjørklund KR. 1998. The taxonomy of boreal Atlantic Ocean Actinommida (Radiolaria). Micropaleontology 44:14960.

Cortese G, Bjørklund KR, Dolven JK. 2003. Polycystine Radiolarians in the Greenland-Iceland-Norwegian (GIN) Seas: species and assemblage distribution. Sarsia 88:65-88.

Crame JA. 1974. Evolutionary history of Antarctica. In: Hempel G, editor. Antarctic Science. Global Concerns. Berlin: Springer. p 188-214.

Crame JA. 1996. Evolution of high-latitude molluscan faunas. In: Taylor J, editor. Origin and Evolutionary Radiation of the Mollusca. Oxford: Oxford University Press. p 119-31.

Dana JD. 1854. On the geographical distribution of Crustacea. American Journal of the Sciences and Arts, Series 2 18(54):314-26.

Darling KF, Kucera M, Pudsey CJ, Wade CM. 2004. Molecular evidence links cryptic diversification in polar plankton protists to Quaternary climate dynamics. Proceedings of the National Academy of Sciences 101:7657-62.

Darling KF, Wade CM, Steward IA, Kroon D, Dingle R, Brown AIL. 2000. Molecular evidence for genetic mixing of Arctic and Antarctic subpolar populations of planktonic foraminifers. Nature 405(6782):43-7.

Darlington PJJ. 1965. Biogeography of the Southern End of the World. Cambridge: Harvard University Press.

Darwin C. 1859. On the Origin of Species by Means of Natural Selection. London: John Murray.

Dayton PK, England KW, Robson EA. 1997. An unusual sea anemone, Dactylanthus antarcticus (Clubb, 1908) (Order Ptychodactiaria), on gorgonians in Chilean fjords. In: Den Hartod JC, editor. Proceedings of the 6th International Conference on Coelenterate Biology. National Natuurhistorisch Museum, Leiden. p 135-42.

De Vries AL. 1970. Freezing resistance in Antarctic fishes. Antarctic Ecology 1:320-8.

De Vries AL, Lin Y. 1977. The Role of Glycoprotein Antifreezes in the Survival of Antarctic Fishes. Adaptation within Antarctic Ecosystems. Washington, DC: Smithsonian Institute. p $439-$ 58.

De Wever P, Dumitrica P, Caulet JP, Nigrini C, Caridroit M. 2001. Radiolarians in the Sedimentary Record. The Netherlands: Gordon and Breach.

Derjugin KM. 1915. Cosmopolitism and bipolar theory. In: Derjugin KM, editor. Fauna of Kola Bay and the Condition of its Existence. Zapiski Imperatorskoy Academii Nauk, FizikoMatematicheskiy Otdel, St.Petersburg. p 124-41.

Dogiel VA, Reshetnjak VV. 1952. Materials on radiolarians of the northwestern part of the Pacific Ocean. Issledovanya Dalnevostochnykh Morei SSSR 3:5-36.

Dollo P. 1904. Poissons. Expedition Antarctique Belge Resultats du Voyage du S.Y. Belgica en 1897-1898-1899 sous le commandement de A. de Gerlache de Gomery. Rapports Scientifiques publies aux frais du gouvernement Belge, sous la direction de la Commission de la Belgica. Zoologie. Antwerp: Buschmann. p 240.

Dolven JK, Bjørklund KR. 2001. An early Holocene peak occurrence and Recent distribution of Rhizoplegma boreale
(Radiolaria): a biomarker in the Norwegian Sea. Marine Micropaleontology 42:25-44.

Dreyer F. 1889. Die Pylombildungen in vergleichen-anatomischer und entwicklungs-geschichtlicher Beziehung bei Radiolarien und bei Protisten uberhaupt, nebst System und Beschreibung neuer und der bis jetzt bekannten pylomatischen Spumellarien. Jenaische Zeitschrift für Naturwissenschaft, Vol. 23, S:77-124.

Dunbar MJ. 1979. The relation between oceans. In: Van der Spoel S, Pierot-Bults AC, editors. Zoogeography and Diversity in Plankton. Utrecht: Bunge. p 112-25.

Eastman JT, DeVries AL. 1985. Adaptation for cryopelagic life in the Antarctic notothenioid fish Pagothenia borchgrevinki. Polar Biology 4:45-52.

Edwards C. 1972. The hydroids and the medusae Podocoryne areolata, P. borealis and P. carnea. Journal of the Marine Biological Association of the UK 5:97-144.

Edwards C. 1973. The medusa Modeeria rotunda and its hydroid Stegopoma fastigiatum, with a review of Stegopoma and Stegolaria. Journal of the Marine Biological Association of the UK 53:573-600.

Edwards C. 1983. The hydroids and medusae Sarsia piriforma sp.nov. and Sarsia striata sp.nov. from the west coast of Scotland, with observation on other species. Journal of the Marine Biological Association of the UK 63:49-60.

Ehrenberg CG. 1862. Uber die Tiefgrund-Verhaltnisse des Oceans am Eingange der Davisstrasse und bei Island. Monatsberichte der Königlichen Preussischen Akademie der Wissenschaften zu Berlin 1862:275-315.

Ehrenberg CG. 1872. Microgeologische Studien uber das kleinste Leben der Meeres-Tiefgrunde aller Zonen und dessen geologischen Einfluss. Monatsberichte der Königlichen Preussischen Akademie der Wissenschaften, Berlin 1872:132-392.

Ehrenberg CG. 1875. Fortsetzung der mikrogeologischen Studien als Gesammt-Uebersicht der mikroskopischen Palaontologie gleichartig analysierter Gebirgsarten der Erde, mit specieller Rucksicht auf den Polycystinen-Mergel von Barbados. Konigliche Akademie der Wissenschaften zu Berlin. Abhandlungen Jahre 1875:1-225.

Ekman S. 1953. Zoogeography of the Sea. London: Sidwick \& Jackson.

Es'kov KY. 1984. The drift of the continents and the problems of the historical biogeography. In: Chernov YI, editor. Faunogenesis and Philocenogenesis. Moscow: Nauka. p 24-92.

Fraser CM. 1940. Some hydroids from the California coast, collected in 1939. Transactions of the Royal Society of Canada Section V 34:39-44

Fraser CM. 1941. New species of hydroids, mostly from the Atlantic Ocean, in the United States National Museum. Proceedings of the US National Museum 91(3125):77-89.

Fraser CM. 1943a. Relationship of North American families of gymnoblastic hydroids. Transactions of the Royal Society of Canada Section V 37:29-33.

Fraser CM. 1943b. Distribution records of some hydroids in the collection of the Museum of Comparative Zoology at Harvard College, with description of new genera and new species. Proceedings New England Zoological Club 22:75-98.

Fraser CM. 1944. Hydroids of the Atlantic Coast of North America. Toronto: University of Toronto Press.

Fraser CM. 1946. Distribution and Relationship in American Hydroids. Toronto: University of Toronto Press.

Geptner VG. 1936. General Zoogeography. Moscow: Biomedgis.

Gibbons MJ, Riland JS. 1989. Intertidal and shallow water hydroids from Fiji. I. Athecata to Sertulariidae. Memoirs of the Queensland Museum 72:377-432.

Golikov AN, Averintsev VG. 1977. Biocenoses of the high parts of the Archipelago Franz Joseph Land and some conformity of their distribution - biocenoses of the shelf of Franz Joseph 
Land and neighbouring aquatories. Issledovanija Fauni Morey 14(22):5-54.

Goll RM, Merinfeld EG. 1979. Radiolaria. In: Fairbridge RW, Jablonski D, editors. Encyclopedia of Paleontology, Encyclopedia of Earth Sciences. Stroudsberg: Dowden, Hutchinson \& Ross. p 673-84.

Gravier-Bonnet N. 1998. Gattya wimleni spec. nov. (Cnidaria: Hydrozoa), a new hydroid from Madagascar, and an identification key to the Gattya species. Zoologische Verhandelingen, Leiden 323:107-24.

Gravier-Bonnet N. 1999. Obelia and other campanulariids (Cnidaria, Hydrozoa) in seagrass beds of Madagascar (Indian Ocean). Zoosystematica Rossica Suppl. 1:77-88.

Gruzov EN. 1985. Biology. Geography of the World Ocean. The Southern Ocean. Moscow: Nauka. p 343-64.

Gruzov EN, Propp MV, Pushkin AF. 1967. Biological communities of the shallow-water areas of the Daevis Sea (on results of the diving investigations). Informatcionniy Bulleten' Sovjetskich Antarcticheskich Expeditsiy 65:124-41.

Haeckel E. 1862. Die Radiolarien (Rhizopoda, Radiata). Eine Monographie. Berlin: Reimer.

Haeckel E. 1881. Prodromus systematis radiolarium. Entwurf eines Radiolarien-System auf Grund von Studien der Challenger - Radiolarien. Jenaische Zeitschrift für Naturwissenschaft 15:418-72.

Haeckel E. 1887. Report on the Radiolaria collected by the H.M.S. "Challenger" during the years 1873-1876. In Thompson CW, Murray J, editors. Report on the Scientific Results of the Voyage of H.M.S. "Challenger" during the Years 1873-1876. Zoology. Edinburgh: Her Majesty's Stationery Office.

Haecker V. 1904. Über die biologische Bedeutung der feineren Strukturen des Radiolarienskelettes. Nebst einem Anhang: Die Phäosphaerien der "Valdivia"-und "Gauss"-Ausbeute. Jenaische Zeitschrift für Naturwissenschaft 39(N.F. Bd. 32): 581-648.

Haecker V. 1908. Tiefsee-Radiolarien. Spezieller Tell. Wissenschaftliche Ergebnisse der Deutschen Tiefsee-Expedition auf dem Damper "Valdivia" 1898-1899, vol. 14, Chun, C., Jena, 336-476.

Haq BU, Berggren WA, Van Couvering JA. 1977. Corrected age of the Pliocene/Pleistocene boundary. Nature (London) 269(5628):483-8.

Harrington HJ, Moore RC. 1956. Trachylinida. Treatise of Invertebrate Paleontology. Part F. Coelenterata. Trachylinida. Boulder: Geological Society of America and University of Kansas Press. p 68-76.

Hasle GR. 1976. The biogeography of some marine planktonic blooms. Deep-Sea Research 23:319-38.

Haug GH, Ganopolski A, Sigman DM, Rosell-Mele A, Swann GEA, Tiedemann R, Jaccard SL, Bollmann J, Maslin MA, Leng MJ, Eglinton G. 2005. North Pacific seasonality and the glaciation of North America 2.7 million years ago. Nature 433:821-5.

Hays JD. 1965. Radiolaria and Late Tertiary and Quaternary History of Antarctic Seas. Biology of the Antarctic Seas. New York: Antarctic Research Series 5. American Geophysical Union. p 125-84.

Helland-Hansen B, Nansen F. 1909. The Norwegian Sea. Report on the Norwegian Fishery Investigations 2:1-359.

Hesse R. 1924. Tiergeographie auf ökologischer Grundlage. Jena: Gustav Fischer.

Hewitt CL, Goddard JHR. 2001. A new species of large and highly contractile hydroid in the genus Candelabrum (Hydrozoa: Anthoathecatae) from southern Oregon, U.S.A. Canadian Journal of Zoology 79:2280-8.
Hirai E, Kakimura Y. 1957. Developmental cycle of Cladonema radiatum var. mayeri Perkins reared in the laboratory. Bulletin of Marine Biology St. Asamushi 8(2-4):49-54.

Hirai E, Yamada M. 1965. On a new athecate hydroid Hataia parva, n.gen., n.sp. Bulletin of Marine Biology St. Asamushi 12(2-3):59-62.

Hirohito ES. 1977. Five hydroid species from the Gulf Aqaba, Red Sea. Biological Laboratory Imperial Household, Tokyo.

Hirohito ES. 1984. A new hydroid Hydractinia bayeri n.sp. (family Hydractiniidae) from the Bay of Panama. Biological Laboratory Imperial Household, Tokyo.

Hirohito TIES. 1988. The hydroid of Sagami Bay I. Athecata. Biological Laboratory Imperial Household, Tokyo, Japan.

Hirohito TIES. 1995. The hydroids of Sagami Bay II. Thecata. Biological Laboratory Imperial Household, Tokyo.

Hollis CJ. 2002. Biostratigraphy and paleoceanography significance of Paleocene radiolarians from offshore eastern New Zealand. Marine Micropaleontology 46:265-316.

Hooker J. 1847. The Botany. A Voyage of Discovery and Research in the Southern and Antarctic Regions during the Years 18391843. London. p 288-302.

Hubbs CL. 1952. Antitropical distribution of fishes and other organisms, Proceedings of the 7th Pacific Science Congress, Whitcome and Tombs, Auckland. New Zealand. p 324-9.

Hubbs CL, Mead GW, Wilimovsky NJ. 1953. The widerspread, probably antitropical distribution and the relationship of the bathypelagic iniomous fish Anotopterus pharao. Bulletin of the Scripps Institute of Oceanography University of California 6:173-97.

Hülsemann K. 1963. Radiolaria in plankton from the Arctic Drifting Station T-3, including the description of three new species. Arctic Institute of North America Technical Paper 13:4-52.

Hyman LH. 1929. Taxonomic studies on the Hydra of North America. I. General remarks and description of Hydra americana new species. Transactions of the American Microscopical Society 48:242-55.

Hyman LH. 1930. Taxonomic studies on the Hydra of North America. II. The characters of Pelmatohydra oligactis Pallas. Transactions of the American Microscopical Society 49:32233.

Hyman LH. 1931a. Taxonomic studies on the Hydra of North America. III. Rediscovery of Hydra carnea Agassiz 1850 with a description of its characters. Transactions of the American Microscopical Society 50:20-9.

Hyman LH. 1931b. Taxonomic studies on the Hydra of North America. IV. Description of three new species with a key to the known species. Transactions of the American Microscopical Society 50:302-15.

Itaki T, Ikehara K, Motoyama I, Hasegawa S. 2004. Abrupt ventilation changes in the Japan Sea over the last $30 \mathrm{ky}$ : evidence from deep-dwelling radiolarians. Palaeogeography, Palaeoclimatology. Palaeoecology 208:263-78.

Jansen E, Slettemark B, Bleil U, Heinrich R, Kringstad L, Rolfsen S. 1989. Oxygen and carbon isotope stratigraphy and magnetostratigraphy of the last $2.9 \mathrm{Ma}$ : paleoclimatic comparisons between the Norwegian Sea and the North Atlantic. Initial Report of the Deep Sea Drilling Project 9:255-69.

Jarms G. 1988. Zur Morphologie, Biologie und Systematik der Nausithoidae (Coronata, Scyphozoa). PhD Dissertation Thesis, University of Hamburg.

Jarms G. 1990. Neubeshreibung dreier Arten der Gattung Nausithoe (Coronata, Scyphozoa) sowie Wiederbeschreibung der Art Nausithoe marginata Kölliker, 1853. Mitteilungen aus dem Zoologischen Museum in Hamburg 87:7-39. 
Jarms G. 1991. Taxonomic characters from the polyp tubes of coronate medusae (Scyphozoa, Coronatae). Hydrobiologia 216/217:463-70.

Jarms G. 1994. Anatomy and phylogenetic significance of Eoconularia loculata, a conulariid from the Silurian of Gotland. Lethaia 27:97-109.

Jarms G. 1997. The polyps of Coronatae (Scyphozoa), a review and some new results. In: Den Hartog JC, editor. Proceedings of the 6th International Conference on Coelenterate Biology. National Natuurhistorisch Museum, Leiden. p 271-8.

Jarms G, Mühlenhardt-Siegl U. 1998. Monobrachium parasitum (Cnidaria: Hydrozoa) epizoic on Antarctic bivalves and its bipolarity. Zoologische Verhandelingen, Leiden 323:125-39.

Johnson DA, Nigrini C. 1980. Radiolarian biogeography in surface sediments of the western Indian Ocean. Marine Micropaleontology 5:111-52.

Johnson DA, Nigrini CA. 1982. Radiolarian biogeography in surface sediments of the eastern Indian Ocean. Marine Micropaleontology 7:237-81.

Jørgensen E. 1900. Protistenplankton aus dem Nordmeere in den Jahren 1897-1900. Bergen Museum Aarbog 1899 6:45-98.

Jørgensen E. 1905. The protist plankton and the diatoms in bottom samples. In: Nordgaard O, editor. Hydrographical and Biological Investigations in Norwegian Fiords. Bergen: Bergen Museum Skrift. p 114-41.

Kafanov AI, Kudrjashov VA. 2000. Marine Biogeography. Moscow: Nauka.

Keany J, Kennett JP. 1972. Pliocene-early Pleistocene paleoclimatic history recorded in Antarctic-subantarctic deep-sea cores. Deep-Sea Research 19:529-48.

Kling SA. 1973. Radiolaria from the eastern North Pacific. Leg 18. Deep Sea Drilling Project. Initial Report of the Deep Sea Drilling Project 18:617-71.

Kling SA. 1976. Relation of radiolarian distributions to subsurface hydrography in the North Pacific. Deep Sea Research 23:1043-58.

Kling SA. 1977. Local and regional imprints on radiolarian assemblages from California coastal basin sediments. Marine Micropaleontology 2:207-21.

Knudsen J. 1970. The systematics and biology of abyssal and hadal Bivalvia. Galathea Report 11:1-244.

Kozlova GE. 1999. Radiolarians from the Paleogene of the Boreal Region of Russia. Practical Manual on Microfauna, 9. All Russia Nauchno-Issled. Vsesoyuzn. Nauchno-Issledovatelskly Geol.-Razvedochniy Institute, St. Petersburg, p 323.

Kramp PL. 1942. Medusae: the Godthaab Expedition, 1928. Meddelelser om Grønland 81(1):1-168.

Kramp PL. 1943a. Hydroida: the zoology of East Greenland. Meddelelser om Grønland 121(11):1-52.

Kramp PL. 1943b. Medusae, Siphonophora, and Ctenophora: the zoology of East Greenland. Meddelelser om Grønland 121(12):1-20.

Kramp PL. 1961. Synopsis of the Medusae of the world. Journal of the Marine Biological Association of the UK 40:469.

Kramp PL. 1963. Summary of the zoological results of the Godhaab Expedition, 1928. Meddelelser om Grønland 81(7):1-115.

Kramp PL. 1965. The Hydromedusae of the Pacific and Indian Oceans. Dana Reports 63:1-162.

Kramp PL. 1968. The Hydromedusae of the Pacific and Indian Oceans. 72, Sections II, III. Dana Reports 200.

KrasheninNIkov VA, Kazarina GK, Kruglikova SB, Mukhina VV, Ushakova MG. 1983. Stratigrafiya pliotsenovykh i chetvertichnykh osadkov vostochno-tikhookeanskogo khrebta i galapagosskoi spredingovoi zony po planktonnym mikroorganizmam [Stratigraphy of Pliocene and Quaternary sediments of the East Pacific Rise and Galapagos spreading]. In: Rauzer-Chernou- sova DM, editor. Zo Voprosy mikropaleontologii [Questions of Micropaleontology]. Moscow: Akademiya Nauk SSSR. p 94-184.

Kruglikova SB. 1969a. Radiolyarii v kolonke st. 4066 (severnaya chast Tikhogo okeana) [Radiolarians in the core of station 4066 (northern part of the Pacific Ocean)]. In: Jouse AP, editor. Osnovnye problemy mikropaleontolgii i organogennogo osadkonakopleniya $\mathrm{v}$ okeanakh i moryakh [Basic Problems of Micropaleontology and of Organogenic Sediment Accumulations in Oceans and Seas]. Moscow: Nauka. p 115-26.

Kruglikova SB. 1969b. Radiolyarii v poverkhnostnom sloe osadkov severnoi poloviny tikhogo okeana [Radiolarians in the surface layer of the sediments of the northern half of the Pacific Ocean]. In: Kort VG, editor. Mikroflora i Mikrofauna v Sovremennykh Osadkakh Tikhogo Okean [Microflora and Microfauna in the Recent Sediments of the Pacific Ocean]. Moscow: Nauka. p 48-72.

Kruglikova SB. 1974. Kharakternye vidy radiolyarii v donnykh osadkakh borealnoi zony tikhogo okeana [Characteristic radiolarian species in the bottom sediments of the boreal zone of the Pacific Ocean]. In: Jouse AP, editor. Mikropaleontologiya okeanov i morei [Micropaleontology of the Oceans and Seas]. Moscow: Nauka.

Kruglikova SB. 1975. Radiolarias at the surface level of the sediments of the Sea of Okhotsk. Oceanologia 15:116-22.

Kruglikova SB. 1977. Radiolaria. In: Zuse AP, editor. Atlas of the Microorganisms in the Bottom Sediments of the Oceans. Moscow: Nauka.

Kruglikova SB. 1988. Radiolaria (Polycystina) from the bottom sediments of Arctic. Izvestia AN SSSR 1:92-102.

Kruglikova SB. 1989a. Arctic ocean Radiolaria. In: Herman I, editor. The Arctic Seas: Climatology, Oceanography, Geology and Biology. New York: Van Nostrand Reinhold. p 461-80.

Kruglikova SB. 1989b. Certain aspects of Radiolarian data as evidence of paleoenvironment. Palaeogeography, Palaeoclimatology. Palaeoecology 69:303-20.

Kruglikova SB. 1995. Structure of the radiolaria-polycystina associations on the species and super-species levels in paleosurroundings. In: Barash MS, editor. Present and Fossil Microplankton of the World Ocean. Moscow: Nauka. p 76-89.

Kruglikova SB. 1999. Distribution of polycystine radiolarians from Recent and Pleistocene sediments of the Arctic-Boreal Zone. Berichte zur Polarforschung. Alfred Wegener Institute for Polar and Marine Research, Bremerhaven 306:120-33.

Kruglikova SB, Bjørklund KR. 2001. Phylum Sarcomastigophora. Class Sarcodina. Subclass Rhizopoda. Order Radiolaria. Issledovanija Fauni Morey 51(59):20-1.

Kubota S. 1978. The life-history of Clytia edwardsi (Hydrozoa: Campanulariidae) in Hokkaido, Japan. Journal of the Faculty of Science Hokkaido University 621:317-54.

Kubota S. 1987. The origin and systematics of four Japanese bivalve-inhabiting hydroids. In: Bouillon J, Boero F, Cicogna F, Cornelius PFS, editors. Modern Trends in the Systematics, Ecology and Evolution of Hydroids and Hydromedusae. Oxford: Clarendon Press. p 275-87.

Kubota S. 1989. Systematic study of a paedomorphic derivative hydrozoan Eugymnanthea (Thecata-Leptomedusae). Zoological Science 6:147-54.

Kubota S. 1991. Taxonomic notes on polyp and medusa of Sarsia nipponica Uchida (Hydrozoa: Corynidae) from the type localty in Japan. Publication of the Seto Marine Biology Laboratory 35(1-3): 17-23.

Kubota S. 1992a. Eucheilota intermedia Kubota is a distinct taxon and the third form of Eutima japonica (Hydrozoa:Leptomedusae). Zoological Science 9:231-5. 
Kubota S. 1992b. Four bivalve-inhabiting hydrozoans in Japan differing in range and host preference. Scientia Marina, Barcelona 56:149-59.

Kubota S. 1993. Resting stage and newly hatched hydroid of a cool water hydrozoan species Climacocodon ikarii Uchida (Hydrozoa, Margelopsidae). Publication of the Seto Marine Biology Laboratory 36:85-7.

Kubota S. 1999. Fauna of Obelia (Cnidaria, Hydrozoa) in Japanese waters, with special reference to life cycle of Obelia dichotoma (L.,1758). Zoosystematica Rossica Suppl. 1:67-76.

Kubota S, Takashima Y. 1992. Redescription of Sarsia japonica (Nagao) (Hydrozoa: Corynidae) from Hokkaido, Japan. Publication of the Seto Marine Biology Laboratory 35(6):371-81.

Kubota S, Yamada M. 1982. Metamorphosis of Hydromedusa Bougainvillia bitentaculata Uchida, 1925. Proceedings of the Japanese Society of Systematic Zoology 24:13-8.

Kubota S, Yamada M. 1992. A new hydroid species Campanularia (Orthopyxis) compressima (Hydrozoa, Cnidaria) from northern Japan. Proceedings of the Japanese Society of Systematic Zoology 47:52-6.

Kussakin OG. 1967. To the Isopoda and Tanaidacea fauna of the shelf zonas of the Antarctic and Subantarctic waters. Issledovanija Fauni Morey 4:220-380.

Larson RJ. 1980. A new Stauromedusa, Kishinouyea corbini (Scyphozoa, Stauromedusae) from the tropical Western Atlantic. Bulletin of Marine Science 30:102-7.

Larson RJ. 1988. Kyopoda lamberti, gen.nov., sp.nov.: an unusual new Stauromedusa (Scyphozoa, Cnidaria) from the eastern Pacific representing a new family. Canadian Journal of Zoology 66:2301-3.

Larson RJ. 1990. Scyphomedusae and cubomedusae from the eastern Pacific. Bulletin of Marine Science 47:546-56.

Larson RJ, Fautin DG. 1989. Stauromedusae of the genus Manania (= Thaumatoscyphus) (Cnidaria, Scyphozoa) in the northern Pacific, including descriptions of new species Manania gwilliami and Manania handi. Canadian Journal of Zoology 67:1543-9.

Larson RJ, Mills CE, Harbison GR. 1991. Western Atlantic midwater hydrozoan and scyphozoan medusae: in situ studies using manned submersibles. Hydrobiologia 216/217:311-7.

Lazarus D. 2002. Environmental control of diversity, evolutionary rates, and taxa longevities in Antarctic Neogene Radiolaria. Palaeontologia Electronica 5:1-32.

Levine ND, Corliss JO, Cox FEG, Deroux G, Grain J, Honigberg BM, Leedale GF, Loeblich AR, Lom J, Lynn D, Merinfeld EG, Page FC, Poljansky GI, Sprague V, Vavra, Wallace FG. 1980. A newly revised classification of the Protozoa. Journal of Protozoology 27:37-58.

Levushkin SI. 1982. Problem of the island faunas in the light of relationship biogeography and ecology. In: Kussakin OG, editor. Marine Biogeography. Subject, Methods, Principles of Districtions. Moscow: Nauka. p 26-52.

Lindberg DR. 1991. Marine biotic interchange between the northern and southern hemispheres. Paleobiology 17:308-24.

Ling HY. 1974. Polycystine Radiolaria and silicoflagellates from surface sediments of the Sea of Okhotsk. Bulletin of the Geological Survey of Taiwan 24:1-11.

Ling HY, Stadum GJ, Welch ML. 1971. Polycystine radiolaria from Bering Sea surface sediment. In: Farinacci A, Matteucci $\mathrm{R}$, editors. Proceedings of the II Planktonic Conference. Edizioni Tecnoscienza, Rome 1970:705-29.

Lombari G, Lazarus DB. 1988. Neogene cycladophorid radiolarians from the North Atlantic, Antarctic, and North Pacific deep-sea sediments. Micropaleontology 34:97-135.

Maas O. 1897. Die Medusen - 21st report on the dredging operations of the U.S. steamer "Albatross" during 1891.
Memoirs of the Museum of Comparative Zoology Harvard College 23:1-92.

Maas O. 1906. Medusen. Expedition Antarctique Belge Resultats du Voyage du S.Y. Belgica en 1897-1898-1899 sous le commandement de A. de Gerlache de Gomery. Rapports Scientifiques publes aux frais du gouvernement Belge, sous la direction de la Comission de la Belgica. Antwerp: Buschmann.

Maas O. 1909. Japanische Medusen. Abhandlungen der mathematische-physiklische Klasse der Königliche Bayerische Akademie der Wissenschaften Suppl. 1(8):52.

Mangerud J. 1992. Naturlige klimavariasjoner. Naturen 2:70-6.

Manton SM. 1940. On two new species of the hydroid Myriothela. British Graham Land Expedition 1934-37 Scientific Reports, British Museum, London 1:255-93.

Mapstone GM. 1998. Bargmannia lata, an undiscribed species of physonect siphonophore (Cnidaria: Hydrozoa) from Canadian Pacific waters. Zoologische Verhandelingen, Leiden 323:141-7.

Margulis RY. 1989. New hydromedusae family Tubulariidae (Coelenterata, Hydrozoa). Zoology Journal 68:125-30.

Margulis RY, Karlsen AG. 1980. New hydroid polyp from genus Hydrocoryne in fauna of the Sea of Japan. Zoology Journal 59:1248-50.

Margulis RY, Karlsen AG. 1985. About colony Bougainvillia superciliaris (L.Agassiz, 1849) (Coelenterata, Hydrozoa) in the White Sea. Vestn. MGU. Biol. Nauki Zoologicheskiy Zurnal 40:54-6.

Marques AC. 1996. A critical analysis of a cladistic study of the genus Eudendrium (Cnidaria: Hydrozoa), with some comments on the family Eudendriidae. Journal of Comparative Biology $1: 153-62$.

Marques AC, Calder DR. 2000. Eudendrium bathyale, a new species of hydroid (Hydrozoa, Anthomedusae, Eudendriidae) from Bermuda. Proceedings of the Biological Society of Washington 113:124-8.

Marques AC, Mergener H, Höinghaus R, Santos CMD, Vervoort W. 2000. Morphological study and taxonomical notes on Eudendriidae (Cnidaria: Hydrozoa: Athecatae/Anthomedusae). Zoological Medicine 74(5):75-118.

Marques AC, Migotto AE. 1998. A new species of Eudendrium (Hydrozoa: Anthomedusae: Eudendriidae) from the Netherlands. Zoologische Verhandelingen, Leiden 323:149-54.

Matul A. 1989. The distribution of radiolarians in the surface layer of North Atlantic bottom sediments. Oceanology 29: $740-5$.

Matul A. 1990. Radiolaria thanatocoenoses in the surface layer of the North Atlantic sediments as a reflection of natural environmental conditions. Oceanology 30:76-9.

Matul A. 1991. Paleoecology of radiolarians and Quaternary paleoceanology of the North Atlantic. PhD Thesis, P. P. Shirshov Institute of Oceanology RAS, Moscow.

Matul A. 1997. Radiolarians in Okhotsk Sea sediments. In: Nürnberg D, Baranov BV, Karp BY, editors. RV Akademik M. A. Lavrentyev Cruise 27 Cruise Report. GEOMAR Report. Geomar, Kiel. p 39-41.

Matul A, Abelmann A, Tiedemann R. 2002. Late Quaternary polycystine radiolarian datum events in the Sea of Okhotsk. Geo-Marine Letters 22:25-32.

McGinitie GE. 1955. Distribution and ecology of the marine invertebrates of Point Barrow, Alaska. Smithsonian Miscellaneous Collection 128(9):1-201.

McIntyre A. 1967. Coccoliths as paleoclimatic indicators of Pleistocene glaciation. Science 158:1314-7.

Mead GW. 1970. A history of South Pacific fishes. Sci. Explor. South Pacif. Proc. Symposium on Scientific Exploration of the South Pacific.La Jolla, Washington D.C., National Academy Science 236-51. 
Medel MD, Lopez-Gonzalez PJ. 1998. Distribution patterns in Atlantic hydroids. Zool. Verhandel. 323:155-68.

Medel MD, Vervoort W. 1995. Plumularian hydroids (Cnidaria: Hydrozoa) from the Strait of Gibraltar and nearby areas. Zoologische Verhandelingen, Leiden 300:1-72.

Medel MD, Vervoort W. 2000. Atlantic Haleciidae and Campanulariidae (Hydrozoa, Cnidaria) collected during the CANCAP and Mauritania-II expeditions of the National Museum of Natural History, Leiden, The Netherlands. Zoologische Verhandelingen, Leiden 330:1-70.

Meisenheimer J. 1905. Pteropoda. Wissenschaftliche Ergebnisse Deutsche Tief-See Expedition 9:1-314.

Mel'nikov NA. 1980. The Short Historical Review of the Crybiological Investigations at the North Isy Ocean. The Biology of the Central Arctic Basin. Moscow: Nauka. p 56-61.

Mel'nikov NA. 1989. Ecology of Arctic Ocean cryopelagic fauna. In: Herman I, editor. The Arctic Seas. Climatology, Oceanography, Geology and Biology. New York: Van Nostrand Reinhold. p 235-55.

Meunier A. 1910. Microplankton des Mers de Barents et de Kara [Microplankton from the Barents and Kara Seas]. Duc d'Orleans, Campagne Arctique de 1907. Brussels: C. Bulens.

Migotto AE. 1996. Benthic shallow-water hydroids (Cnidaria, Hydrozoa) of the coast of Sao Sebastiano, Brazil, including a checklist of Brazilian hydroids. Zoologische Verhandelingen, Leiden 306:1-125.

Migotto AE, Calder DR. 1998. Sertularella vervoorti (Hydrozoa: Sertulariidae). Zoologische Verhandelingen, Leiden 323:16980.

Mileykovskyi SA. 1977. Structure of the area distributions of the bottom animals and the role of the pelagic larvae in area distribution forming. In: Vinogradov ME, editor. Biology of the Ocean. 1. Biological Structure of the Ocean. Moscow: Nauka. p 262-6.

Millard NAH. 1975. Monograph on the Hydroida of Southern Africa, 68:1-513. Annals of the South African Museum.

Millard NAH. 1977. Hydroids from the Kerguelen and Crozet shelves, collected by the cruise MD.03 of the Marion-Dufresne. Annals of the South African Museum 73:1-47.

Millard NAH. 1978. The geographical distribution of southern African hydroids. Annals of the South African Museum 74:159-200.

Millard NAH. 1979. Type specimens of Hydroida (Coelenterata) in the South African Museum. Annals of the South African Museum 77(8):133-50.

Molina-Cruz A, Bernal-Ramirez RG. 1996. Distribution of Radiolaria in surface sediments and its relation to the oceanography of the Iceland and Greenland Seas. Sarsia 81:315-28.

Morley JJ, Nigrini C. 1995. Miocene to Pleistocene radiolarian biostratigraphy of North Pacific sites 881, 884, 885, 886, and 887. Proceedings of the Ocean Drilling Program. 55-91.

Motoyama I. 1997. Origin and evolution of Cycladophora davisiana Ehrenberg (Radiolarian) in DSDP Site 192, Northwest Pacific. Marine Micropaleontology 30:45-63.

Murray J. 1896. On the deep and shallow-water marine fauna of the Kerguelen-Region of the Great Southern Ocean. Transactions of the Royal Society of Edinburgh 38(2):1-494.

Nakaseko K, Nishimura A. 1982. Radiolaria from the bottom sediments of the Bellingshausen Basin in the Antarctic Sea. Report of the Technology Research Center. Japan National Oil Corporation 16:91-244.

Namikawa H. 1991. A new species of the genus Stylactaria (Cnidaria, Hydrozoa) from Hokkaido, Japan. Zoological Science 8:805-12.

Namikawa H, Kubota S, Mawatary SF. 1990. Redescription of Stylactaria uchidai (Yamada, 1947), comb.nov. (Hydrozoa,
Hydractiniidae) in Hokkaido, Japan. Proceedings of the Japanese Society of Systematic Zoology 42:2-9.

Namikawa H, Kubota S, Mawatary SF. 1992. Redescription of Stylactaria conchicola (Yamada, 1947), comb. nov. (Hydrozoa: Hydractiniidae) from Hokkaido, Japan. Hydrobiologia 231:69-76.

Naumov DV. 1960. Hydroids and hydromedusae of the marine, brackish and freshwater basins of SSSR. Opredelitely po faune SSSR Moscow-Leningrad Isd. AN SSSR 70.

Naumov DV. 1961. Scyphomedusae of the SSSR seas. Opredelitely po faune SSSR Moscow-Leningrad Isd. AN SSSR 75.

Naumov DV. 1971. Hydromedusae and Scyphomedusae of the Kurilo-Kamchatsky trough. Trudi Institute Oceanology AN SSSR 92:9-17.

Naumov DV, Stepanjants SD. 1971. A new medusae species Craspedacusta (Hydrozoa) from the marine lagoon. Zoology Journal 50:1094-97.

Nigrini C. 1967. Radiolaria in pelagic sediments from the Indian and Atlantic Oceans. Bulletin of the Scripps Institute of Oceanography University of California 11:1-125.

Nigrini C. 1970. Radiolarian assemblages in the North Pacific and their application to a study of Quaternary sediments in core 120-130. Memoirs of the Geological Society of America 126:139-83.

Nigrini C. 1971. Radiolarian zones in the Quaternary of the equatorial Pacific Ocean. In: Funnel BM, Riedel WR, editors. Micropaleontology of the Ocean. Cambridge: Cambrige University Press. p 443-61.

Nigrini C, Moore TC. 1979. A guide to modern Radiolaria. Cushman Foundation for Foraminiferal Research. Special Publication 16:1-248.

Nimmergut A. 2001. Radiolarienfauna im Ochotskischen Meer eine aktuopaläontologische Charackterisierung der Biozönose und Taphozönose. PhD Thesis, Universität Bremen.

Nishimura A, Nakaseko K, Okuda Y. 1997. A new coastal water radiolarian assemblage recovered from sediment samples from the Antarctic Ocean. Marine Micropaleontology 30:29-44.

Nishimura A, Yamauchi M. 1984a. Radiolarians from the Nankai Trough in the Northwest Pacific. News of Osaka Micropaleontologists Special Volume 6:1-148.

Nishimura A, Yamauchi M. 1984b. Radiolarian fossils in the drilling core samples at the Kansai International Airport in Osaka Bay Geological Survey, Submarine Strata, Kansai International Airport, Osaka Bay, Central Japan, Report Calamity Science Institute, Osaka, Japan.

Norris RD, De Vargas C. 2000. Evidence of gene flow between plankton in the Arctic and Antarctic is one surprise. Another is the discovery of hitherto hidden genetic diversity in these organisms. Nature 405(6782):23-7.

Orlov DV. 1994. Planulae settlement of the colonial hydroids. PhD Thesis, MGU, Moscow.

Orlov DV. 1996. Ecological conditionality of planulae settlement of colonial hydroids. Journal Obschey Biologii 57:112-22.

Ortmann AE. 1896. Grundzüge der marinen Tiergeographie. Jena: Gustav Fischer.

Ortmann AE. 1897. ber "Bipolarität" in der Verbreitung mariner Thiere. Zoologische Jahrbücher. Abteilung der Systematik, Geographie und Biologie der Tiere 9:571-95.

Page FC. 1984. The Sarcodina Protista. In: Petrushevskaya MG, Stepanjants SD, editors. Morphology, Ecology and Evolution of Radiolarians. Leningrad: Nauka. p 22-30.

Pages F. 1997. The gelatinous zooplankton in the pelagic system of the Southern Ocean: a review. Annales de l'Institut Oceanographique. Paris 73:139-58.

Pages F, Bouillon J. 1997. A redescription of Paragotoea bathybia Kramp, 1942 (Hydroidomedusae: Corymorphidae) with a new 
diagnosis for the genus Paragotoea. Scientia Marina 61:48793.

Pages F, Gili J-M, Bouillon J. 1992. Planktonic cnidarians of the Benguela current. Scientia Marina 56(Suppl. 1):1-144.

Pages F, Kurbjeweit F. 1994. Vertical distribution and abundance of mesoplanktonic medusae and siphonophores from the Weddell Sea, Antarctica. Polar Biology 14:243-51.

Panteleeva NN. 1999. Obelia longissima (Pallas, 1766) and Obelia geniculata (L., 1758) (Hydrozoa, Thecaphora, Campanulariidae) in the Barents Sea. Morphology, distribution, ecology and special life history features. Zoosystematica Rossica Suppl. 1:51-65.

Panteleeva NN, Frolova EA, Sheiko OV. 1999. New records of the benthic medusa Ptychogastria polaris Allman, 1878 (Trachylida, Hydroidea) in the Barents Sea and off the Kurile Islands (Pacific Ocean). Polar Biology 22:372-8.

Pasternak FA. 1973. Deepwater marine feathers (Octocorallia, Pennatularia) of the Aleutian trough and Alaska Bay. Trudi Instituta Oceanologii AN SSSR 91:108-27.

Peña Cantero AL. 1998. Two new antarctic species of the genus Schizotricha Allman, 1883. Polar Biology 19:77-84.

Peña Cantero AL, Svoboda A, Vervoort W. 1996. Species of Schizotricha Allman, 1883 (Cnidaria, Hydrozoa) from recent Antarctic expeditions with R.V. "Polarstern", with the description of a new species. Zoological Medicine Leiden 70(28): 411-35.

Peña Cantero AL, Svoboda A, Vervoort W. 1997a. Species of Oswaldella Stechow, 1919 (Cnidaria, Hydrozoa) from recent Antarctic expeditions with R.V. "Polarstern", with the description of eight new species. Zoological Journal of the Linnean Society 119:339-88.

Peña Cantero AL, Svoboda A, Vervoort W. 1997b. Species of Staurotheca Allman, 1888 (Cnidaria, Hydrozoa) from recent Antarctic expeditions with R.V. "Polarstern", with the description of six new species. Journal of Natural History 31:329-81.

Petrushevskaya MG. 1966. Radiolarians in plankton and bottom sediments. In: Geochemistry of the Siliceous. Izdatelstvo Nauka, Moscow 219-45.

Petrushevskaya MG. 1967. Radiolaria of the orders Spumellaria and Nassellaria of the Antarctic Region. Issledovanija Fauni Morey 4(12):6-186.

Petrushevskaya MG. 1969a. Radiolyarii Spumellaria i Nassellaria $\mathrm{v}$ donnykh osadkakh kak indikatory gydrologycheskikh uslovii [Spumellarian and Nassellarian radiolarians in bottom sediments as indicators of hydrological conditions]. In: Jouse AP, editor. Osnovnye Problemy micropaleontologii i organogennovo osadkonakopleniya $\mathrm{v}$ okeanakh i moryakh [Basic Problems of Micropaleontology and the Accumulation of Organogenic Sediments in Oceans and Seas]. Moscow: Nauka. p 127-52.

Petrushevskaya MG. 1969b. Raspredelenie skeletov radiolyarii v osadkakh Severnoi Atlantiki [Distribution of radiolarian skeletons in the sediments of the North Atlantic]. In: Vyalov OS, editor. Iskopaemye i Sovreminnye Radiolyarii: Materialy vtorogo vsesoyuznogo seminara po radiolyariyam [Fossil and Recent Radiolarians: Materials of the Second All Union Seminar on Radiolarians]. Lvov: Izdatelstvo Lvovskogo Universiteta. p 123-32.

Petrushevskaya MG. 1971. Radiolaria Nassellaria at the plankton of the World Ocean. Issledovanija Fauni Morey 9(17):3-294.

Petrushevskaya MG. 1972. Biostratigraphy of the deepwater Quaternary sediments on radiolarian analysis data. Oceanology 12:71-86.

Petrushevskaya MG. 1975. Cenozoic radiolarians from the Antarctic, Leg 29. DSDP. Initial Report of the Deep Sea Drilling Project 14:541-675.
Petrushevskaya MG. 1977. Radiolaria. In: Zuse AP, editor. Atlas of the Microorganisms in the Bottom Sediments of the Oceans. Moscow: Nauka.

Petrushevskaya MG. 1979. New Version of Polycystina System. Fossil and Recent Radiolarians. Leningrad: Leningrad Zoological Institute. p 101-18.

Petrushevskaya MG. 1981. Radiolarians of the Order Nassellaria of the World Ocean. Leningrad: Nauka.

Petrushevskaya MG. 1984. About classification of Polycystina radiolarians. In: Petrushevskaya MG, Stepanjants SD, editors. Morphology, Ecology and Evolution of Radiolaria. Leningrad: Nauka. p 124-49.

Petrushevskaya MG. 1986. Radiolarian Analysis. Leningrad: Nauka.

Petrushevskaya MG, Bjørklund KR. 1974. Radiolarians in Holocene sediments of the Norwegian-Greenland Seas. Sarsia $57: 33-46$.

Petrushevskaya MG, Cachon J, Cachon M. 1976. Comparative morphological study of Radiolaria: foundation of a new taxonomy. Journal of Zoology 55:485-96.

Pfeffer G. 1891. Versuch über die erdgeschichtliche Entwickelung der jetzigen Verbreitungsverhältnisse unserer Tierwelt. Hamburg: Friederichsen.

Pierrot-Bults AC, Van der Spoel S. 1979. Speciation in macrozooplankton. In: Van der Spoel S, Pierrot-Bults AC, editors. Zoogeography and Diversity of Plankton. Utrecht: Bunge. p 144-67.

Popofsky A. 1904. Die Acantharia der Plankton Expedition. T. 1. Acanthometra. Plankton Expedition D. Humboldt Stiftung. Kiel/Leipzig.

Popofsky A. 1908. Die Radiolarien der Antarktis (mit Ausnahme der Tripyleen). Deutsch Südpolar-Expedition 1901-1903. Berlin: Georg Reimer. p 185-308.

Popofsky A. 1913. Die Sphaerellarien des Warmwassergebietes. Deutsch Südpolar-Expedition 1901-1903. Berlin: Georg Reimer. p 75-159.

Pugh PR, Pages F. 1993. A new species of Clausophyes (Siphonophorae, Clausophyidae), with a redescription of $C$. galeata and C. moserae. Journal of the Marine Biological Association of the UK 73:595-608.

Ramil F, Vervoort W. 1992. Pseudoplumaria gen.nov. a new Atlantic genus of the family Plumulariidae (Cnidaria: Hydrozoa). Zoological Medicine Leiden 66(36):485-92.

Ramil F, Vervoort W, Ansin JA. 1998. Report on the Haleciidae and Plumulariidae (Cnidaria, Hydrozoa) collected by the French SEAMOUNT 1 Expedition. Zoologische Verhandelingen, Leiden 322:1-42.

Rasnitzin AP. 1987. Tempos of Evolution and Evolutionary Theory (Hypothesis of Adaptive Compromise). Evolution and Biocenotical Crises. Moscow: Nauka. p 46-64.

Rasnitzin AP. 2002. Evolutionary process and methodology of systematics. Proceedings of the Russian Entomological Society 73.

Rass TS. 1941. Geographic parallelism into structure and developing of the bony fishes of the Northern Seas. Moscow Society of the Investigators of Nature: 1-61.

Rass TS. 1980. Symmetry and asymmetry of the Ichtiofauna of the ocean. Oceanology 20(5):7-14.

Rees WJ, Vervoort W. 1987. Hydroids from the John Murray Expedition to the Indian Ocean, with revisory notes on Hydrodendron, Abietinella, Cryptolaria and Zygophylax (Cnidaria: Hydrozoa). Zoologische Verhandelingen, Leiden 237:1209.

Renz GW. 1976. The distribution and ecology of Radiolaria in the Central Pacific plankton and surface sediments. Bulletin of the Scripps Institute of Oceanography University of California $22: 1-267$. 
Reshetnjak VV. 1955. The vertical distribution of Radiolarians of the Kurilo-Kamchatsky through. Trudi Zoologicheskogo Inst. AN SSSR 21:94-101.

Reshetnjak VV. 1965. Radiolaria, Phaeodaria of the Antarctic waters. Trudi Zoologicheskogo Inst. AN SSSR 35:67-78.

Reshetnjak VV. 1966. Deepwater Radiolaria Phaeodaria of the North-west Pacific. Moscow: Nauka.

Reshetnjak VV. 1981. Acantharia. Protozoa of the World Ocean. Leningrad: Nauka.

Riedel WR. 1958. Radiolaria in Antarctic sediments. Report of the British, Australian, New Zealand Antarctic Research Expedition 1929-1931 Series B. Part (6, Part 10):217-56.

Riedel WR. 1971. Systematic classification of polycystine radiolaria. In: Funnel BM, Riedel WR, editors. Micropaleontology of the Oceans. Cambridge: Cambridge University Press. $p$ 649-61.

Riedel WR, Sanfilippo A. 1970. Radiolaria, Leg 4. Deep Sea Drilling Project. Initial Report of the Deep Sea Drilling Project 6:503-75.

Riedel WR, Sanfilippo A. 1971. Cenozoic Radiolaria from the western tropical Pacific, Leg 7. Initial Report of the Deep Sea Drilling Project 7:1529-671.

Riedel WR, Westberg-Smith MJ, Budai A. 1985. Late Neogene Radiolaria and Mediterranean paleoenvironments. In: Stanley DJ, Wezel FC, editors. Geological Evolution of the Mediterranean Basin. New York: Springer. p 487-523.

Robins MW. 1972. A new commensal hydroid from Antarctica. Bulletin of the British Antarctic Survey 28:75-81.

Ross GA. 1847. Voyage of discovery and research in the Southern and Antarctic regions during the years 1839-1843. London.

Rudels B, Jones EP, Anderson LG, Kattner G. 1994. On the intermediate depth waters of the Arctic Ocean. In: Johannessen OM, Muench RD, Overland JE, editors. The Polar Oceans and their Role in Shaping the Global Environment. Geophysical Monograph. American Geophysical Union, Washington DC. p 33-46.

Russel FS. 1953. The Medusae of the British Isles. Cambridge: Cambridge University Press.

Russel FS. 1970. The Medusae of the British Isles, 2. Cambridge: Cambridge University Press.

Ryland JS, Gibbons MJ. 1991. Intertidal and shallow water hydroids from Fiji. II. Plumulariidae and Aglaophenidae. Memoirs of the Queensland Museum 30(3):525-60.

Schneppenheim R, Theede H. 1982. Freezing-point depressing peptides and glycoproteins from Arctic-boreal and Antarctic fish. Polar Biology 1:115-23.

Schröder O. 1909. Die Nordischen Spumellarien. Teil II. Unterlegion Sphaerellarien. Nordisches Plankton 7(11):1-66.

Schröder O. 1913. Der Tripyleen Radiolarien [Phaeodarien]. In: Drygalski E, editor. Deutsche Sudpolar-Expedition, 19011903. Berlin: Georg Reimer. p 113-215.

Schröder O. 1914. Die nordischen Nassellarien. Nordisches Plankton 7(11):67-146.

Schröder-Ritzrau A. 1995. Aktuopaläontologische Untersuchung zu Verbreitung und Vertikalfluss von Radiolarien sowie ihre räumliche und zeitliche Entwicklung im Europäischen Nordmeer. Berichte aus dem Sonderforschungsbereich 313. Universität zu Kiel 52:1-99.

Schuchert P. 1996. The marine fauna of New Zealand: athecate hydroids and their medusae (Cnidaria: Hydrozoa). Memoirs of the National Institute of Water and Atmospheric Research (NIWA) and New Zealand Oceanography Institute 106:1-159.

Schuchert P. 1997. Review of the family Halopterididae (Hydrozoa, Cnidaria). Zoologische Verhandelingen, Leiden 309:1162.
Schuchert P. 2001a. Hydroids of Greenland and Iceland (Cnidaria, Hydrozoa). Meddelelser om Grønland Bioscience 53:1184.

Schuchert P. 2001b. Survey of the family Corynidae (Cnidaria, Hydrozoa). Revue Suisse de Zoologie 108:739-878.

Schuchert P. 2004. Revision of the European athecate hydroids and their medusae (Hydrozoa, Cnidaria): Families Oceanidae and Pachycordylidae. Revue Suisse de Zoologie III:315-69.

Schwarz SS. 1980. Ecological Conformity of the Evolution. Moscow: Nauka.

Segonzac M, Vervoort W. 1995. First record of the genus Candelabrum (Cnidaria, Hydrozoa, Athecata) from the MidAtlantic Ridge: a description of a new species and a review of the genus. Bulletin du Muséum National d'Histoire Naturelle Paris, 4 Series 17(1/2):31-64.

Semenov VN. 1982. Biogeographical distriction of the shelf of South America on the basis of the classification of the species area distributions of the bottom invertebrates. In: Kussakin OG, editor. Marine Biogeography. Subject, Methods and Principles of Distriction. Moscow: Nauka. p 184-269.

Sheiko OV, Stepanjants SD. 1997a. Medusozoa (Cnidaria: Anthozoa expected) from the Commander Islands, faunistic composition and biogeography. In: Den Hartod JC, editor. Proceedings of the 6th International Conference on Coelenterate Biology. National Natuurhistorisch Museum, Leiden. p 437-45.

Sheiko OV, Stepanjants SD. 1997b. Hydroids (Cnidaria, Hydrozoa) of the shelf of the Commander Islands. In: Rzavsky AV, editor. Bottom Flora and Fauna of the Shelf of the Commander Island. Vladivostok: Dalnauka. p 71-108.

Stanley EM. 1981. Biogeography and evolution of "Bipolar" Radiolaria. PhD Thesis, University of California Davis.

Stechow E. 1919. Neue Ergebnisse auf dem Gebiete der Hydroidenforschung. Sitzungsberichte Gesellschaft für Morphologie und Physiologie München 31:1-37.

Stepanjants SD. 1967. Siphonophora of the USSR Seas and of the North Pacific. Leningrad: Nauka.

Stepanjants SD. 1975. Composition and some peculiarities of the Siphonophora distribution at the Caribbean Sea, Mexico Gulf and at the neighbouring areas of the Atlantic (on the materials of the 14th voyage by "Akademik Kurchatov" vessel). Trudy Instituta Oceanologii Akademii Nauk SSSR 100:96-126.

Stepanjants SD. 1979. Hydroids of the Antarctic and Subantarctic waters. Issledovanija Fauni Morey 22:1-199.

Stepanjants SD. 1980. About cosmopolitism between hydroids. Theoretical and practical significance of coelenterates. Leningrad Zool. Inst. AN SSSR. 114-22.

Stepanjants SD. 1988. Hydromedusae of the Busse Lagoon: species composition and taxonomic comments. Biota and communities of the Far-Eastern Seas: lagoons and bays of Kamchatka and Sakhalin. Vladivostok DVO AN SSSR. 11437.

Stepanjants SD. 1989. Hydrozoa of the Eurasian Arctic Seas. In: Herman I, editor. The Arctic Seas. Climatology, Oceanography, Geology and Biology. New York: Van Nostrand Reinhold. p 397-430.

Stepanjants SD. 1994. Hydroids (Hydrozoa) of the East-Siberian Sea. Issledovanija Fauni Morey 48(56):116-42.

Stepanjants SD. 1998. Obelia (Cnidaria, Medusozoa, Hydrozoa): phenomenon, aspects of investigations, perspectives for utilization. Oceanography and Marine Biology: an Annual Review 36:179-215.

Stepanjants SD. 1999. Obelia (Cnidaria, Hydrozoa). Phenomenon. Aspects of investigations. Perspectives of employment. Zoosystematica Rossica Suppl. 1:1-180.

Stepanjants SD. 2001. Phylum Cnidaria. Subphylum Medusozoa. Issledovanija Fauni Morey 51(59):32-6. 
Stepanjants SD, Kosobokova KN. (in press). Medusae of the genus Rhabdoon (Hydrozoa: Anthomedusae: Tubularioidea) in the Arctic ocean.

Stepanjants SD, Christiansen BO, Svoboda A, Anokhin BA. 2003. The genus Monocoryne (Hydrozoa, Capitata): peculiarities of morphology, species composition, biology and distribution. Sarsia 88:97-106.

Stepanjants SD, Dianov MB. 1997. The computer approach to the study of the morphological and biological peculiarities of siphonophora Dimophyes arctica (Chun,1897). Data bases and computer graphics in zoological investigations. Trudy Zoologicheskogo Instituta Akademii Nauk SSSR. 269:154-65.

Stepanjants SD, Kruglikova SB, Bjørklund KR, Cortese G. 2004. The bipolar distribution of marine organisms with emphasis on Radiolaria and Cnidarians: a step forward. In: Kafanov AI, editor. General Questions of Biogeography: in Memory of the Academician O. G. Kusakina. Vladivostok: Dal'nauka. p 12478.

Stepanjants SD, Lobanov AL. 1989. Ecological peculiarities of the siphonophores Dimophyes arctica (Chun) in Japan Sea. Experience of the multidimensional statistics employment. In: Koltun VM, Marfenin NN, Stepanjants SD, editors. Fundamental Investigations of the Modern Sponges and Coelenterates. Leningrad: Zool. Inst. AN SSSR. p 117-9.

Stepanjants SD, Lobanov AL, Dianov MB. 1999a. New approaches to the search for interspecies diagnostic differences within the genus Obelia. I. Analysis of the morphological characters of Obelia polyp colonies using the BIKEY software package. Zoosystematica Rossica Suppl. 1:29-33.

Stepanjants SD, Lobanov AL, Dianov MB. 1999b. New approaches to the search for interspecies diagnostic differences within the genus Obelia. I. Analysis of the growth and development of free medusae of Obelia spp. from different areas of the World Ocean (under laboratory conditions). Zoosystematica Rossica Suppl. 1:34-50.

Stepanjants SD, Peña Cantero AL, Sheiko OV, Svoboda A. 1997b. Naumovia gen.sp. for Plumularia microtheca Naumov, 1960, a deepwater North Pacific species, with remarks on other genera and species of the family Kirchenpaueriidae (Cnidaria, Hydrozoa). Zoosystematica Rossica 6(1/2):9-20.

Stepanjants SD, Sheiko (Bozhenova) OV, Napara TO. 1990. Fabulosus kurilensis gen. et sp.n. (Hydrozoa, Cnidaria) - a new hydroid polyp on the shelf of the Kurile Islands. Trudy Zoologicheskogo Instituta Akademii Nauk SSSR. Leningrad, 218:5-17.

Stepanjants SD, Svoboda A. 2001. Redescription of Gymnogonos ameriensis (Stepanjants, 1979) and comments on other species of the genus Gymnogonos (Cnidaria, Hydrozoa: Corymorphidae, Corymorphinae). Zoosystematica Rossica 9:247-52.

Stepanjants SD, Svoboda A, Peña Cantero AL, Sheiko OV. 1998. Wimveria gen.nov. for Schizotricha divergens Naumov, 1960, from the Commander Islands, with comments on the scope of the family Kirchenpaueriidae (Cnidaria: Hydrozoa). Zoologische Verhandelingen, Leiden 323:221-45.

Stepanjants SD, Svoboda A, Vervoort W. 1996. The problem of bipolarity, with emphasis on Medusozoa (Cnidaria). Russian Hydrobiological Journal. A Special Issue for the 75 years old of the foundation. SpB. Zool. Inst. RAN. 5-34.

Stepanjants SD, Svoboda A, Vervoort W. 1997a. The problem of bipolarity, with emphasis on the Medusozoa (Cnidaria: Anthozoa excepted). In: Den Hartod JC, editor. Proceedings of the 6th International Conference on Coelenterate Biology. National Natuurhistorisch Museum, Leiden. p 455-64.

Steuer A. 1910. Planktonkunde. Leipzig: Teubner.

Stiasny G. 1934. Das Bipolaritatsproblem. Archiv Nederlandische Zoologie 1:35-53.
Stübing D, Piepenburg D. 1998. Occurence of the benthic trachymedusa Ptychogastria polaris Allman, 1878 (Cnidaria: Hydrozoa) off northeast Greenland and in the northern Barents Sea. Polar Biology 19:193-7.

Svetovidov AN. 1949. About peculiarities of some bipolar area distributions of marine fishes and about their stipulated causes. Izvestiya Vsesojusnogo Geographicheskogo Obschestva 81(1):44-52.

Svoboda A. 1979. Beitrag zur Ökologie, Biometrie und Systematik der Mediterranen Aglaophenia arten (Hydroidea). Zoologische Verhandelingen, Leiden 167:1-114.

Svoboda A, Cornelius PFS. 1991. The European and Mediterranean species of Aglaophenia (Cnidaria: Hydrozoa). Zoologische Verhandelingen, Leiden. 274.

Svoboda A, Stepanjants SD. 2001. Redescription of two Antarctic Corymorphidae species and the reestablishment of the genus Monocaulus (Cnidaria: Hydrozoa). Marine Ecology 22(12):53-70.

Svoboda A, Stepanjants SD, Ljubenkov J. in press. Genus Bouillonia (Cnidaria: Hydrozoa: Athecata). Three species from the northern and southern hemispheres, with discussion on bipolar distribution of this genus. Zool. Mededlingen, Leiden.

Svoboda A, Stepanjants SD, Smirnov IS. 1995. Zwei polare Hydractiniiden-Arten (Hydroidea, Cnidaria) als Symbionten nahe verwandter Schlangensterne (Ophiolepididae, Echinodermata) - ein ökologisches Beispiel für Bipolarität. Berichte zur Polarforschung 155:86-9.

Svoboda A, Stepanjants SD, Smirnov IS. 1997. Two polar Hydractinia species (Cnidaria), epibiotic on two closely related brittle stars (Echinodermata): an example for a taxonomic and ecological bipolarity. In: Valencia J, Walton DW, editors. / Antarctic Communities. Cambridge: Cambridge University Press. p 22-5.

Takahashi K. 1981. Vertical flux, ecology and dissolution of Radiolaria in tropical oceans: implications for the silica cycle. Doctoral dissertation. Woods Hole Oceanographic Institution, Massachusetts Institute of Technology, WHOI-81-103, 1-460.

Takahashi K. 1991. Mineral flux and biogeochemical cycles of marine planktonic protozoa session summary. NATO ASI Series 25:347-59.

Takahashi K, Honjo S. 1981. Vertical flux of Radiolaria: a taxonquantitative sediment trap study from the western tropical Atlantic. Micropaleontology 27:140-90.

Theel H. 1886. Report on the Holothuroidea. Voyage of H.M.S. Challenger, Part II, Zoology, 4.

Thompson AW. 1897. 1898. On a supposed resemblance between the marine faunas of the Arctic and Antarctic regions. Proceedings of the Royal Society of Edinburgh 22:311-49.

Tibbs JF. 1967. On some planktonic Protozoa taken from the track of drift station ARLIS I, 1960-61. ARCTIC (Journal of the Arctic Institute of North America) 20:247-54.

Uchida T. 1970. Revision of Japanese Cubomedusae. Publications of the Seto Marine Biology Laboratory 17:289-97.

Ushakov PV. 1958. Subantarctic Islands Macquarie and Kerguelen. Priroda 3:58-63.

Van der Spoel S. 1991. Hydromedusan distribution pattern. Hydrobiologia 216/217:489-96.

Van der Spoel S, Heyman RP. 1983. A Comparative Atlas of Zooplankton. Biological Patterns in the Oceans. Utrecht: Bunge.

Vanhöffen E. 1902. Die Acraspedoten Medusen der deutschen Tiefsee-Expedition 1898-1899. Wiss. Ergebn. "Valdivia" 3: $1-86$.

Vanhöffen E. 1906. Acraspedae Gegenbaur 1856. Nordisches Plankton 5(11):40-64. 
Vervoort W. 1959. The Hydroida of the tropical west coast of Africa. Atlantide Report, 1945-1946, Report. Scientific Research of the Danish Expeditions to the coasts of tropical West Africa 5:211-325.

Vervoort W. 1966. Bathyal and abyssal hydroids. Galathea Report, Scientific Research of the Danish Expeditions Deep Sea Expedition 1950-1952:97-173.

Vervoort W. 1967. Hydroida and Chondrophora of the Israel South Red Sea Expedition. Israel South Red Sea Expedition, 1962. Bulletin of the Sea Fisheries Research Station Israel. Report 25:18-54.

Vervoort W. 1968. Report on a collection of Hydroida from the Caribbean region, including an annotated checklist of Caribbean hydroids. Zoologische Verhandelingen, Leiden 92:1-124.

Vervoort W. 1972. Hydroids from the Theta, Vema and Yelcho Cruises of the Lamont-Doherty Geological Observatory. Zoologische Verhandelingen, Leiden 120:1-247.

Vervoort W. 1985. Deep-water hydroids. In: Laubier L, editor. Peuplements profonds du golfe de Gascogne. Campagnes Biogas, Institut Français de recherche pour l'exploitation de la mer. Brest: IFREMER. p 267-97.

Vervoort W. 1993a. Cnidaria, Hydrozoa: Hydroids from the Western Pacific (Philippines, Indonesia and New Caledonia). I: Sertulariidae (Part 1). Memoirs du Museum National d'Histoire Naturelle, Paris 158:89-298.

Vervoort W. 1993b. Report on hydroids (Hydrozoa, Cnidaria) in the collection of the Zoological Museum, University of TelAviv, Israel. Zoological Medicine Leiden 67(40):537-65.

Vervoort W, Vasseur P. 1977. Hydroids from French Polynesia with notes on distribution and ecology. Zoologische Verhandelingen, Leiden. 159.

Vinogradov ME. 1959. About quantitative distribution of the deepwater plankton in the western and central parts of the Pacific Ocean and its connection with the deep waters circulation. Dokladi Akademii Nauk SSSR 127(4):877-880.

Vinogradov ME. 1965. The vertical distribution of the oceanic zooplankton. PhD Thesis, Institute of Oceanology AN SSSR.

Vinogradov ME. 1968. The vertical distribution of the oceanic zooplankton. Moscow: Nauka.

Vinogradova NG. 1955. Some peculiarities of the marine deepwater fauna distribution. Trudi Inst. Oceanologii AN SSSR 13:59-66.

Vinogradova NG. 1969. Geographical distribution of the deepwater bottom fauna. The Pacific Ocean. Biology of the Pacific Ocean. 1:154-81.

Vinogradova NG. 1977. The bottom fauna of the abyssal and ultraabissal. In: Vinogradov ME, editor. Biology of the Ocean, 2. Biological Structure of the Ocean. Moscow: Nauka. p $281-$ 98.
Vishnevskaya VS. 1991. Otkrytie yurskikh radiolyarii Amphipyndacidae na dalnem vostoke SSSR [The discovery of Jurassic Radiolaria Amphipyndacidae in the far east of the USSR]. In: Paleontologo stratigraficheskie issledovaniya fanerozoya dalnego vostoka (po rezultatam radiolyarievogo analiza dlya kartirovaniya) [Paleontological and Stratigraphic Investigation of Phanerozoic in the Far Eastern Region (by the Results of Radiolarian Analysis)]. Far East Division (DVO) of the Academy of Sciences of the USSR, Vladivostok, pp 63-67.

Vishnevskaya VS. 2001. Jurassic to Cretaceous Radiolarian Biostratigraphy of Russia. Moscow: GEOS. p 376.

Voronov AG, Drosdov NN, Krivolutskyi DA, Mjalo EG. 2002. Biogeography with the Basical Ecology. Moscow: Visshaya shkola.

Watson JE. 1985. The genus Eudendrium (Hydrozoa: Hydroida) from Australia. Proceedings of the Royal Society of Victoria 97(4):179-221.

Watson JE. 1992. Revision of the family Lineolariidae Allman, 1864 (Hydrozoa: Hydroida). Proceedings of the Royal Society of Victoria 104:81-7.

Watson JE. 1998. Troglodytes of a muddy bottom: the hydroid fauna of holes in the seabed. Zoologische Verhandelingen, Leiden 323:247-56.

Watson JE, Vervoort W. 2001. The hydroid fauna of Tasmanian seamounts. Zoologische Verhandelingen, Leiden 334:151-87.

Weaver FM. 1976. Antarctic Radiolaria from the Southeast Pacific Basin. Leg 35. Deep Sea Drilling Project. Initial Report of the Deep Sea Drilling Project 35:569-603.

White M. 1977. Ecological Adaptation by Antarctic Poikilotherms to the Polar Marine Environment. Adaptation within Antarctic Ecosystems. Washington, DC: Smithsonian Institute. p $197-$ 208.

White M, North A. 1985. Reproductive strategies in Antarctic fish. Proceedings of the 5th Congress of the European Ichtyologists, Stockholm. p 157.

Yamada M. 1964. Rhizogeton ezoense n.sp., a new hydroid from Hokkaido, Japan. Journal of the Faculty of Science Hokkaido University Series Zoology 15:395-7.

Yamada M, Kubota S. 1991. Notes on the morphology, ecology and life cycles of Fulaurahydra anthoformis and Hataia parva (Hydrozoa, Athecata). Hydrobiologia 216/217:159-64.

Zenkevitch LA. 1948. Biological structure of the Ocean. Zoology Journal 25:113-24.

Zenkevitch LA. 1960. A special quantitative characterization of the deepwater life of the ocean. Isvestiya Akademii Nauk SSSS. Serija Geograficheskaja 2:10-6.

Editorial responsibility: Tom Fenchel 


\section{Appendix 1. Bipolar radiolarians}

\begin{tabular}{|c|c|c|c|}
\hline Taxa & $\begin{array}{l}\text { Distribution in } \\
\text { hemispheres Northern }\end{array}$ & Southern & References \\
\hline \multicolumn{4}{|l|}{ Superorder Phaeodaria } \\
\hline \multicolumn{4}{|l|}{ Family Aulacanthidae } \\
\hline 1. Aulacantha laevissima Haeckel & Ar, Bor A P & An & Reshetnjak 1965, 1966 \\
\hline 2. Aulodendron verticillatum Haecker & H Bor P & An & Reshetnjak 1965, 1966 \\
\hline $\begin{array}{l}\text { 3. Auloceros arborescens irregularis } \\
\text { Haecker }\end{array}$ & H Bor P & An & Reshetnjak 1965, 1966 \\
\hline 4 Aulagraphonium antarcticum Haecker & H Bor P & An & Reshetnjak 1965, 1966 \\
\hline \multicolumn{4}{|l|}{ Family Aulosphaeridae } \\
\hline 5. Aulastrum spinosum Borgert & H Bor A P & An & $\begin{array}{l}\text { Haecker 1904, 1908; Schröder 1913; Dogiel } \\
\text { \& Reshetnjak 1952; Hülsemann 1963; } \\
\text { Reshetnjak 1965, } 1966\end{array}$ \\
\hline \multicolumn{4}{|l|}{ Family Castanellidae } \\
\hline 6. Castanura primitiva Reshetnjak & H Bor P & An & Reshetnjak 1965, 1966 \\
\hline 7. Castanidium inclinatum Reshetnjak & H Bor P & An & Reshetnjak 1965, 1966 \\
\hline \multicolumn{4}{|l|}{ Family Sagosphaeridae } \\
\hline 8. Sagenoscena irmingeriana Borgert & H Bor A P & An & $\begin{array}{l}\text { Dogiel \& Reshetnjak 1952; Reshetnjak 1965, } \\
1966\end{array}$ \\
\hline \multicolumn{4}{|l|}{ Family Coelodendridae } \\
\hline 9. Coelographis antarcticus Haecker & H Bor P & An & $\begin{array}{l}\text { Jørgensen 1905; Dogiel \& Reshetnjak 1952; } \\
\text { Hülsemann 1963; Reshetnjak 1952, 1965, } \\
1966\end{array}$ \\
\hline \multicolumn{4}{|l|}{$\begin{array}{l}\text { Superorder Polycystina } \\
\text { Order Spumellaria }\end{array}$} \\
\hline \multicolumn{4}{|l|}{ Family Actinommidae } \\
\hline 10. Actinomma boreale Cleve & H Bor A P & An SubAn & $\begin{array}{l}\text { Cleve 1899; Jørgensen 1905; Hülsemann } \\
\text { 1963; Tibbs 1967; Bjørklund 1973, 1976; } \\
\text { Kruglikova 1977; Cortese \& Bjørklund 1998; } \\
\text { Stanley 1981; Nishimura \& Yamauchi 1984a; } \\
\text { Nakaseko \& Nishimura 1982; Itaki 2004; } \\
\text { Cortese (unpubl.) }\end{array}$ \\
\hline $\begin{array}{l}\text { 11. A. leptoderma leptoderma } \\
\text { (Jørgensen) }\end{array}$ & Ar Bor A P & An SubAn & $\begin{array}{l}\text { Jørgensen 1900, 1905; Schröder 1909; } \\
\text { Bernstein 1934; Bogorov 1946; Hülsemann } \\
\text { 1963; Tibbs 1967; Bjørklund 1973, 1974, } \\
\text { 1976; Kruglikova 1989a; Abelmann 1992a,b; } \\
\text { Abelmann \& Gowing 1997; Nishimura et al. } \\
\text { 1997; Bjørklund et al. 1998; Cortese \& } \\
\text { Bjørklund 1998; Bjørklund \& Kruglikova } \\
2003\end{array}$ \\
\hline $\begin{array}{l}\text { 12. A. leptoderma longispina Cortese \& } \\
\text { Bjørklund }\end{array}$ & H Bor A P & An SubAn & $\begin{array}{l}\text { Cortese \& Bjørklund 1998; Nishimura \& } \\
\text { Yamauchi 1984a,b; Cortese (unpubl.); } \\
\text { Kruglikova (unpubl.) }\end{array}$ \\
\hline $\begin{array}{l}\text { 13. A. popofskii (=Echinomma } \\
\text { popofskii) Petrushevskaya }\end{array}$ & H Bor A P Tr & An & $\begin{array}{l}\text { Cortese \& Bjørklund 1998; Petrushevskaya } \\
\text { 1967; Kruglikova 1969a, b; Matul 1997; } \\
\text { Cortese et al. 2003; Cortese (unpubl.) }\end{array}$ \\
\hline $\begin{array}{l}\text { 14. A. delicatulum (=Echinomma } \\
\text { delicatulum) (Dogiel, Reshetnjak) }\end{array}$ & H Bor A P Tr & An SubAn & $\begin{array}{l}\text { Dogiel \& Reshetnjak 1952; Riedel 1958; } \\
\text { Petrushevskaya 1967, 1969; Kruglikova } \\
\text { 1969a,b; Ling et al. 1971; Nakaseko \& } \\
\text { Nishimura 1982; Matul 1989, 1990, 1991, } \\
\text { 1997; Nishimura et al. 1997; Bjørklund } \\
\text { (unpubl.). }\end{array}$ \\
\hline 15. Rhizoplegma boreale (Cleve) & Ar Bor A P & An SubAn & $\begin{array}{l}\text { Petrushevskaya 1969; Ling et al. 1971; } \\
\text { Kruglikova 1975, 1977; Kling 1977; Ling } \\
\text { et al. 1971; Nishimura et al. 1997; Dolven \& } \\
\text { Bjørklund 2001; Nimmergut 2001; Bjørklund } \\
\text { \& Kruglikova 2003; Cortese (unpubl.) }\end{array}$ \\
\hline
\end{tabular}




\begin{tabular}{|c|c|c|c|}
\hline Taxa & $\begin{array}{l}\text { Distribution in } \\
\text { hemispheres Northern }\end{array}$ & Southern & References \\
\hline 16. Prunopyle (?) antarctica Dreyer & Ar Bor A P & An SubAn & $\begin{array}{l}\text { Dreyer 1889; Riedel 1958; Petrushevskaya } \\
\text { 1967, 1975; Kling 1973; Petrushevskaya } \\
\text { 1975; Chen 1975; Kruglikova 1977; Stanley } \\
\text { 1981; Benson (unpubl.); Nakaseko \& } \\
\text { Nishimura 1982; Bjørklund (unpubl.). }\end{array}$ \\
\hline $\begin{array}{l}\text { 17. P.(?) tetrapila Hays }(=P \text {. (?) } \\
\text { robusta Kling) }\end{array}$ & Bor P Tr & SubAn & $\begin{array}{l}\text { Hays 1965; Kling 1973; Petrushevskaya 1975; } \\
\text { Chen 1975, Stanley } 1981\end{array}$ \\
\hline $\begin{array}{l}\text { Family Druppulidae } \\
\text { 18. Stylatractus pyriformis (S. } \\
\text { neptunus = Dorydruppa bensoni) } \\
\text { (Bailey) }\end{array}$ & Bor A P Tr P & An SubAn & $\begin{array}{l}\text { Bailey 1856; Kruglikova 1977; Petrushevs- } \\
\text { kaya 1967, 1977; Takahashi 1991; Benson } \\
\text { 1966; Bjørklund (unpubl.). }\end{array}$ \\
\hline $\begin{array}{l}\text { Family Sponguridae } \\
\text { 19. Spongurus pylomaticus (Riedel) }\end{array}$ & NP & An SubAn & $\begin{array}{l}\text { Riedel 1958; Petrushevskaya 1967, 1975; } \\
\text { Kruglikova 1969a, b, 1977; Ling et al. 1971; } \\
\text { Stanley 1981; Nishimura et al. 1997; Matul } \\
1997\end{array}$ \\
\hline $\begin{array}{l}\text { Family Trematodiscidae } \\
\text { 20. Stylodictya validispina Jørgensen } \\
(=\text { S. stellata Bailey) }\end{array}$ & Ar Bor A P Subtr & An SubAn & $\begin{array}{l}\text { Jørgensen 1905; Petrushevskaya 1967; Kru- } \\
\text { glikova 1969b, 1977; Matul 1989, 1990, } \\
\text { 1991, 1997; Schröder-Ritzrau 1995; } \\
\text { Bjørklund et al. 1998; Cortese (unpubl.) }\end{array}$ \\
\hline 21. S. aculeata Jørgensen & Bor A P & An SubAn & $\begin{array}{l}\text { Jørgensen 1905; Petrushevskaya 1967; } \\
\text { Kruglikova 1969b; Matul 1997; Cortese \& } \\
\text { Bjørklund } 1998\end{array}$ \\
\hline 22. Stylochlamydium venustum (Bailey) & Bor A P Subtr? & An SubAn & $\begin{array}{l}\text { Bailey 1856; Petrushevskaya 1967, 1969; } \\
\text { Kruglikova 1969a, b, 1975, 1977, 1999; Ling } \\
\text { et al. 1971; Nigrini \& Moore 1979; Blueford } \\
\text { 1983; Matul 1989, 1990, 1991, 1997; } \\
\text { Nimmergut 2001; Cortese (unpubl.) }\end{array}$ \\
\hline \multicolumn{4}{|l|}{ Family Spongodiscidae } \\
\hline 23. Spongotrochus glacialis Popofsky & Ar Bor A P Tr & An SubAn & $\begin{array}{l}\text { Popofsky 1908; Riedel 1958; Hülsemann } \\
\text { 1963; Tibbs 1967; Petrushevskaya 1967, } \\
\text { 1975; Kling 1973; Chen 1975; Kruglikova } \\
\text { 1975, 1977; Blueford 1983; Matul 1989, } \\
\text { 1990, 1991, 1997; Bjørklund \& } \\
\text { Kruglikova 2003 }\end{array}$ \\
\hline \multicolumn{4}{|l|}{$\begin{array}{l}\text { Superorder Polycystina } \\
\text { Order Nassellaria }\end{array}$} \\
\hline \multicolumn{4}{|l|}{ Family Sethophormididae } \\
\hline 24. Enneaphormis rotula Haeckel & Ar Bor A P Tr? & An SubAn & $\begin{array}{l}\text { Tibbs 1967; Kruglikova 1977; Nakaseko \& } \\
\text { Nishimura 1982; Takahashi 1981; } \\
\text { Petrushevskaya 1981, 1986; Matul 1989, } \\
\text { 1990, 1991, 1997; Schröder-Ritzrau 1995; } \\
\text { Bjørklund \& Kruglikova } 2003\end{array}$ \\
\hline 25. E. enneastrum Haeckel & Ar Bor A P Tr & An SubAn & $\begin{array}{l}\text { Cleve 1900; Jørgensen 1905; Popofsky 1908; } \\
\text { Hülsemann 1963; Petrushevskaya 1971; } \\
\text { Nakaseko \& Nishimura 1982; Nishimura \& } \\
\text { Yamauchi 1984a,b; Bjørklund \& Kruglikova } \\
\text { 2003; Cortese (unpubl.) }\end{array}$ \\
\hline 26. Protoscenium simplex (Cleve) & Ar Bor A P & An SubAn & $\begin{array}{l}\text { Cleve 1899; Jørgensen 1905; Petrushevskaya } \\
\text { 1971; Bjørklund \& Kruglikova } 2003\end{array}$ \\
\hline \multicolumn{4}{|l|}{ Family Plagiacanthidae } \\
\hline 27. Sethophylium meunieri Schroeder & $\mathrm{Ar}$ & An & $\begin{array}{l}\text { Meunier 1910; Schröder 1914; Petrushevs- } \\
\text { kaya 1977; Bjørklund \& Kruglikova } 2003\end{array}$ \\
\hline $\begin{array}{l}\text { 28. Pseudodictyophimus gracilipes } \\
\text { gracilipes (Bailey) }\end{array}$ & Ar Bor A P Tr & LAn SubAn & $\begin{array}{l}\text { Bailey 1856; Petrushevskaya 1967, 1971; } \\
\text { Petrushevskaya \& Bjørklund 1974; Takahashi } \\
\text { 1981; Schroder-Ritzrau 1995; Kruglikova } \\
\text { 1975, 1999; Bjorklund et al. 1998; } \\
\text { Nimmergut 2001; Bjorklund \& Kruglikova } \\
2003\end{array}$ \\
\hline
\end{tabular}




\begin{tabular}{|c|c|c|c|}
\hline Taxa & $\begin{array}{c}\text { Distribution in } \\
\text { hemispheres Northern }\end{array}$ & Southern & References \\
\hline $\begin{array}{l}\text { 29. P.gracilipes Bailey bicornis } \\
\text { Ehrenberg }\end{array}$ & Ar Bor A P & An SubAn & $\begin{array}{l}\text { Schröder 1914; Petrushevskaya 1967, 1971; } \\
\text { Kruglikova 1975; Bjorklund \& Kruglikova } \\
2003\end{array}$ \\
\hline 30. Ceratocyrtis histricosa Jørgensen & Ar Bor A P Subtr & An SubAn? & $\begin{array}{l}\text { Jørgensen 1905; Hays 1965; Kruglikova 1977; } \\
\text { Petrushevskya 1967, 1977; Matul 1989, } \\
\text { 1990, 1991, 1997; Schröder-Ritzrau 1995; } \\
\text { Bjørklund \& Kruglikova 2003; Cortese } \\
\text { (unpubl.) }\end{array}$ \\
\hline 31. Lophophaena clevei Petrushevskaya & Ar Bor A P & An & $\begin{array}{l}\text { Cleve 1899; Hülsemann 1963; Petrushevs- } \\
\text { kaya 1971; Matul 1997; Bjørklund \& } \\
\text { Kruglikova } 2003\end{array}$ \\
\hline 32. Phormacantha hystrix Joergensen & Ar Bor A P & An SubAn & $\begin{array}{l}\text { Hülsemann 1963; Benson 1966, 1983; Tibbs } \\
\text { 1967; Petrushevskaya 1969, 1971, 1986; } \\
\text { Matul 1997; Boltovskoy 1998; Abelmann } \\
\text { 1992; Schröder-Ritzrau 1995; Nishimura } \\
\text { et al. 1997; Nimmergut 2001; Bjørklund et al. } \\
\text { 1998; Bjørklund \& Kruglikova 2003; Cortese } \\
\text { (unpubl.) }\end{array}$ \\
\hline 33. Plectacantha oikiskos Jørgensen & Ar Bor A P & An & $\begin{array}{l}\text { Jørgensen 1900, 1905; Hülsemann 1963; } \\
\text { Tibbs 1967; Petrushevskaya 1971; } \\
\text { Kruglikova 1977; Abelmann 1992; Matul } \\
\text { 1997; Bjørklund et al. 1998; Bjørklund \& } \\
\text { Kruglikova } 2003\end{array}$ \\
\hline \multicolumn{4}{|l|}{ Genus Mitrocalpis } \\
\hline 34. Mitrocalpis araneafera Popofsky & Ar Bor P & An & $\begin{array}{l}\text { Popofsky 1908; Riedel 1958; Petrushevskaya } \\
\text { 1971; Ling et al. 1971; Nakaseko \& } \\
\text { Nishimura 1982; Matul 1997; Lazarus 2002; } \\
\text { Bjørklund \& Kruglikova } 2003\end{array}$ \\
\hline \multicolumn{4}{|l|}{ Family Eucyrtidiidae } \\
\hline 35. Sethoconus tabulatus (Ehrenberg) & Bor A P & An SubAn & $\begin{array}{l}\text { Ehrenberg 1872; Haeckel 1887; Cleve } \\
\text { 1899; Hülsemann 1963; Petrushevskaya } \\
\text { 1967, 1971; Ling 1974; Kruglikova } \\
\text { 1969b, 1975, 1977; Bjøklund et al. 1998; } \\
\text { Boltovskoy 1987; Matul 1989, 1990, 1991, } \\
\text { 1997; Nimmergut 2001; Bjørklund \& } \\
\text { Kruglikova 2003; Cortese (unpubl.) }\end{array}$ \\
\hline 36. Artostrobus annulatus (Bailey) & Ar Bor A P Tr & An SubAn & $\begin{array}{l}\text { Bailey 1856; Petrushevskaya 1967, 1971; } \\
\text { Kruglikova 1969, 1975, 1977; Bjørklund } \\
\text { 1976; Takahashi 1981; Abelmann 1992; } \\
\text { Bjørklund et al. 1998; Nimmergut 2001; } \\
\text { Bjørklund \& Kruglikova } 2003\end{array}$ \\
\hline 37. A. joergenseni Petrushevskaya & Ar Bor A P Tr & An SubAn & $\begin{array}{l}\text { Petrushevskaya 1967, 1971; Bjørklund 1976; } \\
\text { Schröder-Ritzrau 1995; Molina-Cruz \& } \\
\text { Bernal-Remirez 1996; Nimmergut 2001; } \\
\text { Bjørklund \& Kruglikova 2003; Cortese } \\
\text { (unpubl.); Kruglikova (unpubl.) }\end{array}$ \\
\hline $\begin{array}{l}\text { 38. Lithomitra lineata clevei } \\
\text { Petrushevskaya }\end{array}$ & Ar Bor A P Tr & An SubAn & $\begin{array}{l}\text { Riedel 1958; Petrushevskaya 1969, 1972, } \\
\text { 1986; Kruglikova 1969b, 1975, 1977, } \\
\text { 1999; Krasheninkov et al. 1983; } \\
\text { Petrushevskaya \& Bjørklund 1974; } \\
\text { Schröder-Ritzrau 1995; Matul 1989, } \\
\text { 1990, 1991, 1997; Bjørklund et al. 1998; } \\
\text { Bjørklund \& Kruglikova } 2003\end{array}$ \\
\hline 39. L. lineata arachnea (Ehrenberg) & Bor A P Tr & An & $\begin{array}{l}\text { Riedel 1958; Kruglikova 1969a, b, 1977; } \\
\text { Petrushevskaya 1967, 1969, 1977; } \\
\text { Petrushevskaya \& Bjørklund 1974; Matul } \\
\text { 1989, 1990, 1991, 1997; Nimmergut } 2001\end{array}$ \\
\hline
\end{tabular}




\begin{tabular}{|c|c|c|c|}
\hline Taxa & $\begin{array}{c}\text { Distribution in } \\
\text { hemispheres Northern }\end{array}$ & Southern & References \\
\hline $\begin{array}{l}\text { 40. Cycladophora davisiana (Ehrenberg) } \\
\text { davisiana (Petrushevskaya) }\end{array}$ & $\begin{array}{l}\text { Ar Bor A P } \\
\text { Subtr Tr }\end{array}$ & An SubAn & $\begin{array}{l}\text { Ehrenberg 1862; Cleve 1899, 1901; } \\
\text { Riedel 1958; Hülsemann 1963; } \\
\text { Petrushevskaya 1967, 1971, 1986; } \\
\text { Petrushevskaya \& Bjørklund 1974; Chen } \\
\text { 1975; Kruglikova 1969b, 1977; Kling 1977; } \\
\text { Nigrini \& Moore 1979; Stanley 1981; } \\
\text { Krasheninkov et al. 1983; Nishimura \& } \\
\text { Yamauchi 1984; Bjørklund \& Ciesielski } \\
\text { 1994; Schröder-Ritzrau 1995; Matul 1989, } \\
\text { 1990, 1991, 1997; Bjørklund \& Kruglikova } \\
\text { 2003; Cortese (unpubl.) }\end{array}$ \\
\hline $\begin{array}{l}\text { 41. C. davisiana (Ehrenberg,) } \\
\text { cornutiodes (Petrushevskaya) } \\
\text { (= Halycaliptra cornuta Bailey = } \\
\text { Cycladophora cosma cosma Lombari \& } \\
\text { Lasarus) }\end{array}$ & $\begin{array}{l}\text { Ar Bor A P } \\
\text { Subtr Tr P }\end{array}$ & An SubAn & $\begin{array}{l}\text { Petrushevskaya 1967, 1979; Kruglikova } \\
\text { 1969b, 1977; Kling 1973; Stanley 1981; } \\
\text { Takahashi 1981; Nakaseko \& Nishimura } \\
\text { 1982; Krasheninkov et al. 1983; Lombari \& } \\
\text { Lazarus 1988; Schröder-Ritzrau 1995; } \\
\text { Morley \& Nigrini 1995; Matul 1997; } \\
\text { Bjørklund et al. 1998; Matul et al. 2002; } \\
\text { Cortese (unpubl.) }\end{array}$ \\
\hline 42. Dictyocephalus hirundo (Haeckel) & Bor A P Tr & An SubAn & $\begin{array}{l}\text { Riedel 1958; Petrushevskaya 1967, 1971; } \\
\text { Kruglikova 1975, 1977; Takahashi 1981; } \\
\text { Abelmann 1992; Nimmergut } 2001\end{array}$ \\
\hline 43. Corocalyptra craspedota (Joergensen) & Ar Bor A P Tr & An SubAn & $\begin{array}{l}\text { Jørgensen 1900, 1905; Schröder 1914; } \\
\text { Petrushevskaya 1971, 1977, 1986; } \\
\text { Krasheninkov et al. 1983; Bjørklund 1976; } \\
\text { Matul 1989, 1990, 1991; Schröder-Ritzrau } \\
\text { 1995; Bjøklund et al. 1998; Bjørklund \& } \\
\text { Kruglikova } 2003\end{array}$ \\
\hline $\begin{array}{l}\text { 44. Androcyclas gamphonycha } \\
\text { (Jørgensen) }\end{array}$ & Bor A P & SubAn P & $\begin{array}{l}\text { Jørgensen 1900, 1905; Schröder 1914; } \\
\text { Hays 1965; Bjørklund 1976; Nigrini \& } \\
\text { Moore 1979; Bjørklund et al. 1998; } \\
\text { Petrushevskaya 1971, 1977, 1986; } \\
\text { Matul 1989, 1990, 1991; Schröder- } \\
\text { Ritzrau 1995 }\end{array}$ \\
\hline \multicolumn{4}{|l|}{ Family Cannobotryidae } \\
\hline 45. Artobotys borealis (Cleve) & Ar, Bor A P Tr & An SubAn & $\begin{array}{l}\text { Cleve 1899; Petrushevskaya 1971; } \\
\text { Petrushevskaya \& Bjørklund 1974; } \\
\text { Bjørklund 1976; Takahashi 1981; } \\
\text { Molina-Cruz \& Bernal-Ramires 1996; } \\
\text { Bjørklund et al. 1998; Nimmergut 2001; } \\
\text { Bjørklund \& Kruglikova 2003; Cortese } \\
\text { (unpubl.) }\end{array}$ \\
\hline 46. Botryocampe inflata (Bailey) & Bor AP & An & $\begin{array}{l}\text { Bailey 1856; Kruglikova 1969b, 1974, 1975, } \\
\text { 1977; Petrushevskaya 1971, 1975, 1981; } \\
\text { Ling et al. 1971; Matul 1989, 1990, 1991, } \\
\text { 1997; Nimmergut 2001; Bjørklund (unpubl.); } \\
\text { Cortese (unpubl.). }\end{array}$ \\
\hline
\end{tabular}

A, Atlantic; Am, American; An, Antarctic; Ar, Arctic; As, Asiatic; B, bipolar; Bd, bipolar deep water; Bl, Black Sea; Bor, boreal; GlAn, "Glacial Antarctic" subregion; H, high; Haw Isl, Hawaiian Islands; Mc, Macquaire; NZ, New Zealand; P, Pacific; NP, northern Pacific; Pat, Patagonian Shelf; SAf, South Africa; SAm, South America; SAu, South Australia; SG, South Georgia; SNZ, South New Zealand Island; Subtr, subtropical; SubAnIsl, Subantarctic islands; Tr, tropical; ?, doubt. 


\section{Appendix 2. Bipolar Medusozoa}

\begin{tabular}{|c|c|c|c|c|}
\hline \multirow[b]{2}{*}{ Taxa } & \multirow{2}{*}{$\begin{array}{c}\text { Type of bipolar } \\
\text { distribution }\end{array}$} & \multicolumn{2}{|c|}{ Distribution in hemispheres } & \multirow[b]{2}{*}{ References } \\
\hline & & Northern & Southern & \\
\hline \multicolumn{5}{|l|}{ Class Hydrozoa } \\
\hline \multicolumn{5}{|l|}{ Order Anthoathecata } \\
\hline Genus Rhizogeton $(6)^{\star}$ & $\mathrm{B}$ & Ar Bor A P & SAf, SNZ & $\begin{array}{l}\text { Millard 1975; Bouillon 1985; } \\
\text { Schuchert 1996, } 2004\end{array}$ \\
\hline Genus Rhizorhagium (3)* & $\mathrm{B}$ & Ar Bor A P & GlAn SubAnIsl SNZ & Bouillon 1985; Schuchert 1996 \\
\hline Family Monobrachiidae` & $\mathrm{B}$ & Ar Bor A P & GlAn SubAnIsl & \\
\hline Genus Monobrachium (3) & $\mathrm{B}$ & Ar Bor A P & GlAn SubAnIsl & $\begin{array}{l}\text { Robins 1972; Bouillon 1975; } \\
\text { Jarms \& Mühlenhardt-Siegel } 1998\end{array}$ \\
\hline $\begin{array}{l}\text { 1. M. parasitum } \\
\text { Mereschk }\end{array}$ & $\mathrm{B}$ & Ar Bor A P & GlAn SubAnisl & Jarms \& Mühlenhardt-Siegel 1998 \\
\hline Genus Paragotoea $(1 \text { ? })^{\star}$ & $\mathrm{Bd}$ & $\begin{array}{l}\text { HAr } \\
\text { Bor-Subtr d } \\
\text { A }\end{array}$ & GlAn d & $\begin{array}{l}\text { Kramp 1942; Bouillon 1985; Margulis 1989; } \\
\text { Pages \& Bouillon } 1997\end{array}$ \\
\hline 2. P. bathybia Kramp & $\mathrm{Bd}$ & $\begin{array}{l}\text { HAr } \\
\text { Bor-Subtr d } \\
\text { A }\end{array}$ & GlAn d & Margulis 1989; Pages \& Bouillon 1997 \\
\hline Genus Rhabdoon? $(2)^{\star}$ & $\mathrm{Bd}$ & $\begin{array}{l}\text { HAr d? } \\
\text { Subtr }\end{array}$ & SubAn & Margulis 1989; Bouillon \& Boero 2000 \\
\hline Genus Gymnogonos (5?)^ & $\mathrm{B}$ & $\mathrm{HAr}$ & GlAn & Stepanjants \& Svoboda 2001 \\
\hline Genus Monocaulus $(4)^{\star}$ & $\mathrm{B}$ & Har HP & GlAn & Svoboda \& Stepanjants 2001 \\
\hline Genus Bouillonia $(3 ?)^{\star}$ & $\mathrm{B}$ & $\begin{array}{l}\text { HAr HA } \\
\text { BorA } \\
\text { SubtrA }\end{array}$ & GlAn SubAnIsl & Svoboda et al. in press \\
\hline Family Candelabridae` & B & Ar Bor A P & GlAn SubAnIsl SAf & Bouillon 1985; Hewitt \& Goddard 2001 \\
\hline Genus Candelabrum $(15 \text { ? })^{\star}$ & $\mathrm{B}$ & Ar Bor A P & GlAn SubAnIsl SAf & $\begin{array}{l}\text { Millard 1975; Segonzac \& Vervoort 1995; } \\
\text { Hewitt \& Goddart } 2001\end{array}$ \\
\hline Genus Monocoryne (5?) ${ }^{\star}$ & $\mathrm{B}$ & Ar Bor A P & GlAn SAf & Calder 1972a; Stepanjants et al. 2003 \\
\hline Genus Margelopsis (5) ${ }^{\star}$ & B & $\begin{array}{l}\text { Bor Subtr A } \\
\text { P Ind? }\end{array}$ & GlAn ubAnIsl & Kramp 1961; Bouillon 1985 \\
\hline Family Rosalindidae ${ }^{\star}$ & $\mathrm{B}$ ? & $\begin{array}{l}\text { Bor Subtr A } \\
\text { P }\end{array}$ & SAust & Bouillon 1985 \\
\hline Genus Rosalinda $(4 ?)^{\star}$ & $\mathrm{B}$ & $\begin{array}{l}\text { Bor Subtr A } \\
\text { P }\end{array}$ & SAust & Antsulevitch \& Stepanjants 1985 \\
\hline \multicolumn{5}{|l|}{$\begin{array}{l}\text { Order Thacaphora } \\
\text { Genus Obelia (5?) }\end{array}$} \\
\hline 3. O. longissima (Pallas) & $\mathrm{B}$ & $\begin{array}{l}\text { Ar Bor } \\
\text { Subtr A P Bl }\end{array}$ & $\begin{array}{l}\text { GlAn SubAnIsl Pat, } \\
\text { SNZ }\end{array}$ & Cornelius 1995b; Stepanjants 1998, 1999 \\
\hline Genus Tulpa (3)^ & $\mathrm{B}$ & $\begin{array}{l}\text { Ar Bor } \\
\text { Subtr A P }\end{array}$ & $\begin{array}{l}\text { SubAnIsl Pat SAf } \\
\text { SNZ }\end{array}$ & Vervoort 1972; Millard 1977; Stepanjants 1979 \\
\hline \multicolumn{5}{|l|}{ Genus Filellum (6?) } \\
\hline 4. F. serpens (Hassal) & $\mathrm{B}$ & $\begin{array}{l}\text { Ar Bor } \\
\text { Subtr A P } \\
\text { HawIsl? }\end{array}$ & GlAn Pat SAf TrAf d & $\begin{array}{l}\text { Vervoort 1972; Millard 1975; } \\
\text { Sheiko \& Stepanjants 1997a,b }\end{array}$ \\
\hline Genus Grammaria (5?)* & $\mathrm{B}$ & $\begin{array}{l}\text { Ar Bor } \\
\text { Subtr A P }\end{array}$ & SubAnIsl Pat SG & Cornelius 1995; Hirohito 1995 \\
\hline 5. G. abietina (Sars) & B & $\begin{array}{l}\text { Ar Bor } \\
\text { Subtr A P }\end{array}$ & SubAnIsl Pat SG & Sheiko \& Stepanjants 1997a, b; Schuchert 2001 \\
\hline \multicolumn{5}{|l|}{ Genus Acryptolaria $\left(4^{\star}\right)$} \\
\hline 6. A. conferta (Allman) & $\mathrm{B}$ & $\begin{array}{l}\text { WAr Bor } \\
\text { Subtr A P }\end{array}$ & Pat NZ SAf Tr d & Stepanjants 1989; Schuchert 2001 \\
\hline Genus Zygophylax (53?) & $\mathrm{B}$ ? & $\begin{array}{l}\text { Ar Bor } \\
\text { Subtr Tr A } \\
\text { P }\end{array}$ & SubAnIsl Pat Tr P? & Rees \& Vervoort 1987 \\
\hline Genus Calycella $(4)^{\star}$ & $\mathrm{B}$ ? & Ar Bor A P & Pat SAf & Millard 1975; Bouillon 1985 \\
\hline Genus Staurophora (2?) ${ }^{\star}$ & B & Ar Bor A P & SubAnIsl Pat & Kramp 1961; Bouillon \& Boero 2000 \\
\hline 7. St. mertensi Brandt & $\mathrm{B}$ & Ar Bor A P & SubAnIsl Pat & Arai \& Brinckmann-Voss 1980 \\
\hline
\end{tabular}




\begin{tabular}{|c|c|c|c|c|}
\hline \multirow[b]{2}{*}{ Taxa } & \multirow{2}{*}{$\begin{array}{l}\text { Type of bipolar } \\
\text { distribution }\end{array}$} & \multicolumn{2}{|c|}{ Distribution in hemispheres } & \multirow[b]{2}{*}{ References } \\
\hline & & Northern & Southern & \\
\hline Genus Ptychogena $(7 ?)^{\star}$ & B & $\begin{array}{l}\text { Ar Bor } \\
\text { Subtr A P }\end{array}$ & GlAn SubAnIsl & Arai \& Brinckmann-Voss 1980 \\
\hline Genus Halopsis (2?) ${ }^{\star}$ & $\mathrm{B}$ & WAr Bor A & Pat & Bouillon \& Boero 2000 \\
\hline 8. H. ocellata Agassiz & B & WAr Bor A & Pat & Kramp 1961 \\
\hline Genus Parascyphus (2?) ${ }^{\star}$ & B & WAr Bor A & $\begin{array}{l}\text { SubAnIsl SAf SNZ } \\
\text { SAust }\end{array}$ & Stepanjants 1979; Bouillon 1985 \\
\hline \multicolumn{5}{|l|}{ Genus Sertularella (150?) } \\
\hline $\begin{array}{l}\text { 9. S. gayi (Lamouroux, } \\
\text { 1821) }\end{array}$ & $\mathrm{B}$ ? & $\begin{array}{l}\text { Ar Bor } \\
\text { Subtr A P } \\
\text { Tr d }\end{array}$ & Pat SNZ & Stepanjants 1979; Calder \& Vervoort 1998; \\
\hline $\begin{array}{l}\text { 10. S. polyzonias } \\
\text { (Linnaeus) }\end{array}$ & $\mathrm{B}$ ? & $\begin{array}{l}\text { Ar Bor } \\
\text { Subtr A P }\end{array}$ & SunAnIsl SAf Pat & $\begin{array}{l}\text { Schuchert 2001a } \\
\text { Vervoort 1972; Stepanjants 1979; Cornelius 1995b; }\end{array}$ \\
\hline \multicolumn{5}{|l|}{$\begin{array}{l}\text { Genus Symplectoscyphus } \\
\text { (110?) }\end{array}$} \\
\hline $\begin{array}{l}\text { 11. S. tricuspidatus } \\
\text { (Alder) }\end{array}$ & B & Ar Bor A P & Pat & $\begin{array}{l}\text { Stepanjants 1979; Hirohito 1995; Cornelius 1995; } \\
\text { Schuchert } 2001\end{array}$ \\
\hline $\begin{array}{l}\text { Genus Staurotheca }(20 ?)^{\star} \\
\text { Genus Abietinaria }(40 ?)\end{array}$ & B & Bor P & GlAn SubAnIsl & Stepanjants 1979; Peña Cantero et al. 1997b \\
\hline $\begin{array}{l}\text { 12. A. abietina } \\
\text { (Linnaeus) }\end{array}$ & $\mathrm{B}$ ? & $\begin{array}{l}\text { Ar Bor } \\
\text { Subtr A P }\end{array}$ & SAf Pat & $\begin{array}{l}\text { Stepanjants 1979; Hirohito 1995; } \\
\text { Sheiko \& Stepanjants } 1997\end{array}$ \\
\hline \multirow[t]{2}{*}{ Family Kirchenpaueriidae ${ }^{\star}$} & $\begin{array}{l}\mathrm{B} \\
\mathrm{B} ?\end{array}$ & $\begin{array}{l}\text { Bor P } \\
\text { Ar Bor } \\
\text { Subtr A P } \\
\text { Tr? d }\end{array}$ & $\begin{array}{l}\text { Pat SNZ } \\
\text { GlAn SubAnIsl Pat } \\
\text { SAf }\end{array}$ & Antsulevitch \& Vervoort 1993 \\
\hline & & & SNZ & $\begin{array}{l}\text { Cornelius 1995; Ramil et al. 1998; } \\
\text { Schuchert } 2001\end{array}$ \\
\hline $\begin{array}{l}\text { Genus Kirchenpaueria } \\
(6 ?)^{\star}\end{array}$ & $\mathrm{B}$ ? & $\begin{array}{l}\text { Ar Bor } \\
\text { Subtr AP } \\
\text { Tr? }\end{array}$ & SAf SNZ SAust & Stepanjants et al. 1997, 1998; Schuchert 2001 \\
\hline $\begin{array}{l}\text { 13. K. pinnata } \\
\text { (Linnaeus) }\end{array}$ & $\mathrm{Ba}$ & Ar Bor A P & SAf & Millard 1975; Hirohito 1995 \\
\hline $\begin{array}{l}\text { 14. K. bonnevieae } \\
\text { (Billard) }\end{array}$ & B & $\begin{array}{l}\text { Ar Bor } \\
\text { Subtr A P }\end{array}$ & SAf SNZ & Schuchert 2001 \\
\hline Genus Schizotricha $(10 ?)^{\star}$ & B & $\begin{array}{l}\text { Ar Bor } \\
\text { Subtr A P }\end{array}$ & $\begin{array}{l}\text { GlAn SubAnIsl SAf } \\
\text { Pat }\end{array}$ & Peña Cantero et al. 1996; Schuchert 1997, 2001 \\
\hline \multicolumn{5}{|l|}{ Genus Halopteris (30?) } \\
\hline $\begin{array}{l}\text { 15. H. catharina } \\
\text { (Johnston) }\end{array}$ & $\mathrm{Ba}$ & Bor Subtr A & Pat & Schuchert 1997, 2001 \\
\hline \multicolumn{5}{|l|}{ Genus Nemertesia (6?) } \\
\hline $\begin{array}{l}\text { 16. N. antennina } \\
\text { (Linnaeu) }\end{array}$ & B & $\begin{array}{l}\text { Ar Bor } \\
\text { Subtr A P }\end{array}$ & SAf & Millard 1975; Schuchert 2001 \\
\hline \multicolumn{5}{|l|}{ Order Trachymedusa } \\
\hline Genus Botrynema $(2)^{\star}$ & B & $\begin{array}{l}\text { Ar Bor } \\
\text { Subtr A B d }\end{array}$ & GlAn SubAn d & Kramp 1961; Bouillon \& Boero 2000 \\
\hline 17. B. brucei Browne & $\mathrm{Bd}$ & $\begin{array}{l}\text { Ar Bor A P } \\
\text { d }\end{array}$ & GlAn SubAn d & Kramp 1961; Bouillon \& Boero 2000 \\
\hline Genus Voragonema $(3 ?)^{\star}$ & $\mathrm{Bd}$ & Bor P d & GlAn d & Naumov 1971; Bouillon et al. 2002 \\
\hline Family Ptychogastriidae* & $\mathrm{Bd}$ & $\begin{array}{l}\text { Ar Bor } \\
\text { Subtr A P d }\end{array}$ & GlAn SubAn d & $\begin{array}{l}\text { Kramp 1961; Sübing \& Piepenburg 1998; } \\
\text { Panteleeva et al. } 1999\end{array}$ \\
\hline Genus Ptychogastria $\left(3\right.$ ? $^{\star}$ & $\mathrm{Bd}$ & $\begin{array}{l}\text { Ar Bor } \\
\text { Subtr A P d }\end{array}$ & GlAn SubAn d & Panteleeva et al. 1998 \\
\hline 18. P. polaris Allman & $\mathrm{Bd}$ & $\begin{array}{l}\text { Ar Bor } \\
\text { Subtr A P d }\end{array}$ & GlAn SubAn d & Panteleeva et al. 1999 \\
\hline \multicolumn{5}{|l|}{ Order Limnomedusa } \\
\hline Genus Craspedacusta $(6 ?)^{\star}$ & $\mathrm{B}$ & $\begin{array}{l}\text { Bor Subtr } \\
\text { As Eu Am }\end{array}$ & Aust SAm & Kramp 1961; Bouillon \& Boero 2000 \\
\hline 19. C. sowerbyi Lancester & B & $\begin{array}{l}\text { Bor Subtr } \\
\text { As Eu Am }\end{array}$ & Aust SAm & Kramp 1961 \\
\hline
\end{tabular}




\begin{tabular}{|c|c|c|c|c|}
\hline \multirow[b]{2}{*}{ Taxa } & \multirow{2}{*}{$\begin{array}{c}\text { Type of bipolar } \\
\text { distribution }\end{array}$} & \multicolumn{2}{|c|}{ Distribution in hemispheres } & \multirow[b]{2}{*}{ References } \\
\hline & & Northern & Southern & \\
\hline \multicolumn{5}{|l|}{ Class Siphonophora } \\
\hline \multicolumn{5}{|l|}{ Order Physophorae } \\
\hline Genus Marrus $(3)^{\star}$ & B & $\begin{array}{l}\text { Ar Bor A P } \\
d\end{array}$ & $\begin{array}{l}\text { GlAn SubAn SAf } \\
\text { SNZ d }\end{array}$ & Stepanjants 1967; Alvarino 1971 \\
\hline \multicolumn{5}{|l|}{ Order Calycophorae } \\
\hline Genus Dimophyes $(1)^{\star}$ & B & $\begin{array}{l}\text { Ar Bor } \\
\text { Subtr APTr } \\
\text { d }\end{array}$ & GlAn SubAn Tr d & Stepanjants 1967; Pages et al. 1992 \\
\hline 20. D. arctica (Chun) & B & $\begin{array}{l}\text { Ar Bor } \\
\text { Subtr APTr } \\
\text { d }\end{array}$ & GlAn SubAn Tr d & Stepanjants 1975; Pages et al. 1992 \\
\hline \multicolumn{5}{|l|}{ Genus Muggiaea (4?) } \\
\hline $\begin{array}{l}\text { 21. M. bargmannae } \\
\text { Totton }\end{array}$ & B & $\begin{array}{l}\text { Ar Bor } \\
\text { Subtr A P }\end{array}$ & GlAn SubAn & Stepanjants 1967; Alvarino 1971 \\
\hline \multicolumn{5}{|l|}{ Class Scyphozoa, Order } \\
\hline Genus Atolla $(2 ?)^{\star} ?$ & $\mathrm{Bd}$ & & & \\
\hline 22. A. wyvillei Haeckel & $\mathrm{Bd}$ & $\begin{array}{l}\text { Subtr Ar } \\
\text { Bor A P Tr }\end{array}$ & An SubAn & Kramp 1942, 1961 \\
\hline Genus Periphylla (1?)*? & $\mathrm{Bd}$ & & & \\
\hline $\begin{array}{l}\text { 23. P. periphylla } \\
\text { (Peron et Lesueur) }\end{array}$ & $\mathrm{Bd} ?$ & $\begin{array}{l}\text { Ar Bor A P } \\
\text { Subtr Tr }\end{array}$ & An SubAn & Kramp 1942, 1961 \\
\hline
\end{tabular}

*Bipolar taxa at above the species level.

The number in parentheses is the total number of species in the genus. 